Prepared in cooperation with the Idaho Department of Water Resources

\title{
Groundwater-Flow Model for the Wood River Valley Aquifer System, South-Central Idaho
}

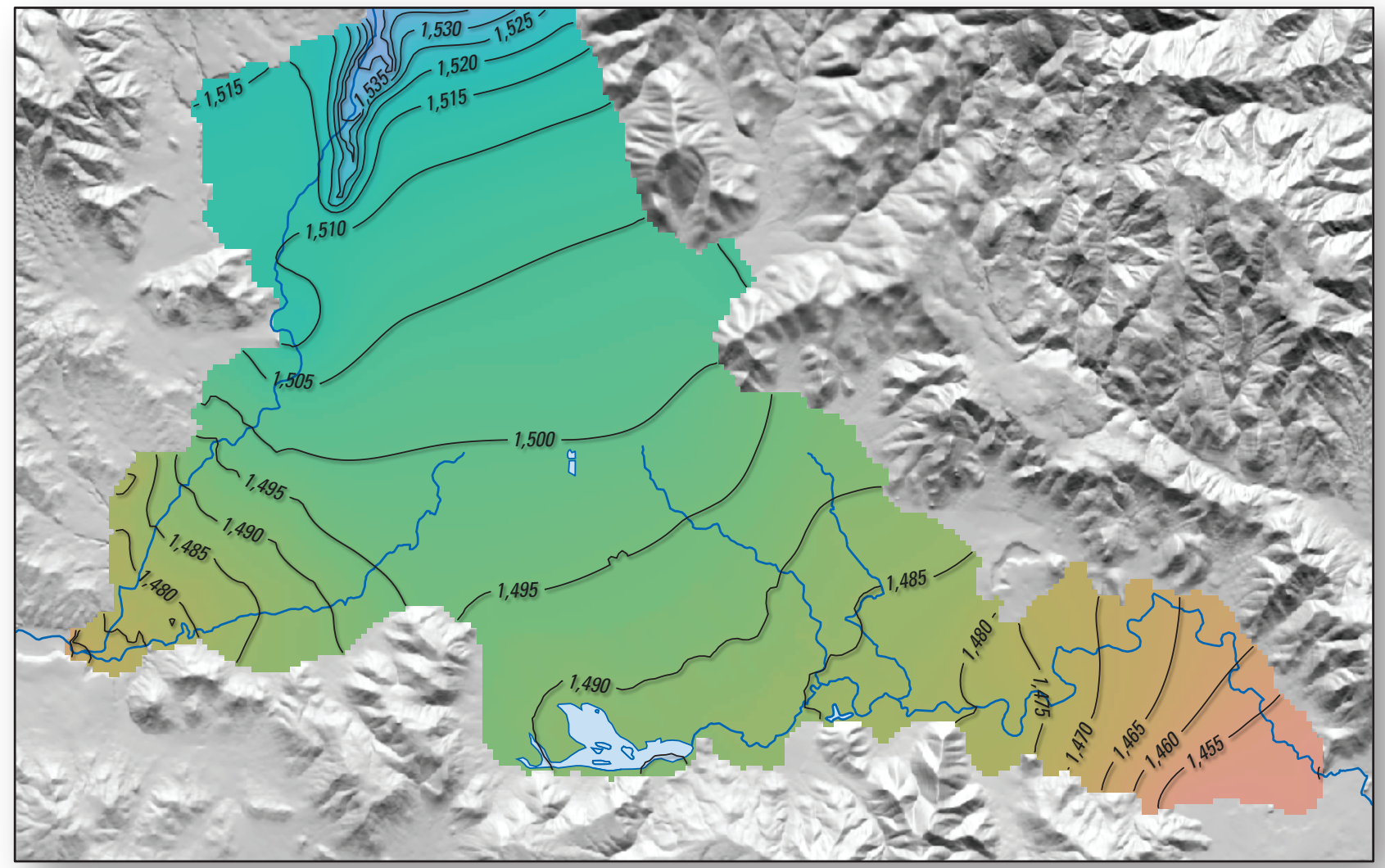

Scientific Investigations Report 2016-5080 
Cover: Map showing simulated hydraulic heads at the water table and south of Bellevue, south-central Idaho, December 2010. Hydraulic head is in meters above North American Vertical Datum of 1988. Water-table contour interval is 5 meters (16 feet). 


\section{Groundwater-Flow Model for the Wood River Valley Aquifer System, South-Central Idaho}

By Jason C. Fisher, James R. Bartolino, Allan H. Wylie, Jennifer Sukow, and Michael McVay

Prepared in cooperation with the Idaho Department of Water Resources

Scientific Investigations Report 2016-5080 


\title{
U.S. Department of the Interior SALLY JEWELL, Secretary
}

\section{U.S. Geological Survey Suzette M. Kimball, Director}

\author{
U.S. Geological Survey, Reston, Virginia: 2016
}

For more information on the USGS - the Federal source for science about the Earth, its natural and living resources, natural hazards, and the environment—visit http://www.usgs.gov or call 1-888-ASK-USGS.

For an overview of USGS information products, including maps, imagery, and publications, visit http://store.usgs.gov.

Any use of trade, firm, or product names is for descriptive purposes only and does not imply endorsement by the U.S. Government.

Although this information product, for the most part, is in the public domain, it also may contain copyrighted materials as noted in the text. Permission to reproduce copyrighted items must be secured from the copyright owner.

Suggested citation:

Fisher, J.C., Bartolino, J.R., Wylie, A.H., Sukow, Jennifer, and McVay, Michael, 2016, Groundwater-flow model of the Wood River Valley aquifer system, south-central Idaho: U.S. Geological Survey Scientific Investigations Report 2016-5080, 71 p., http://dx.doi.org/10.3133/sir20165080.

ISSN 2328-0328 (online) 


\section{Contents}

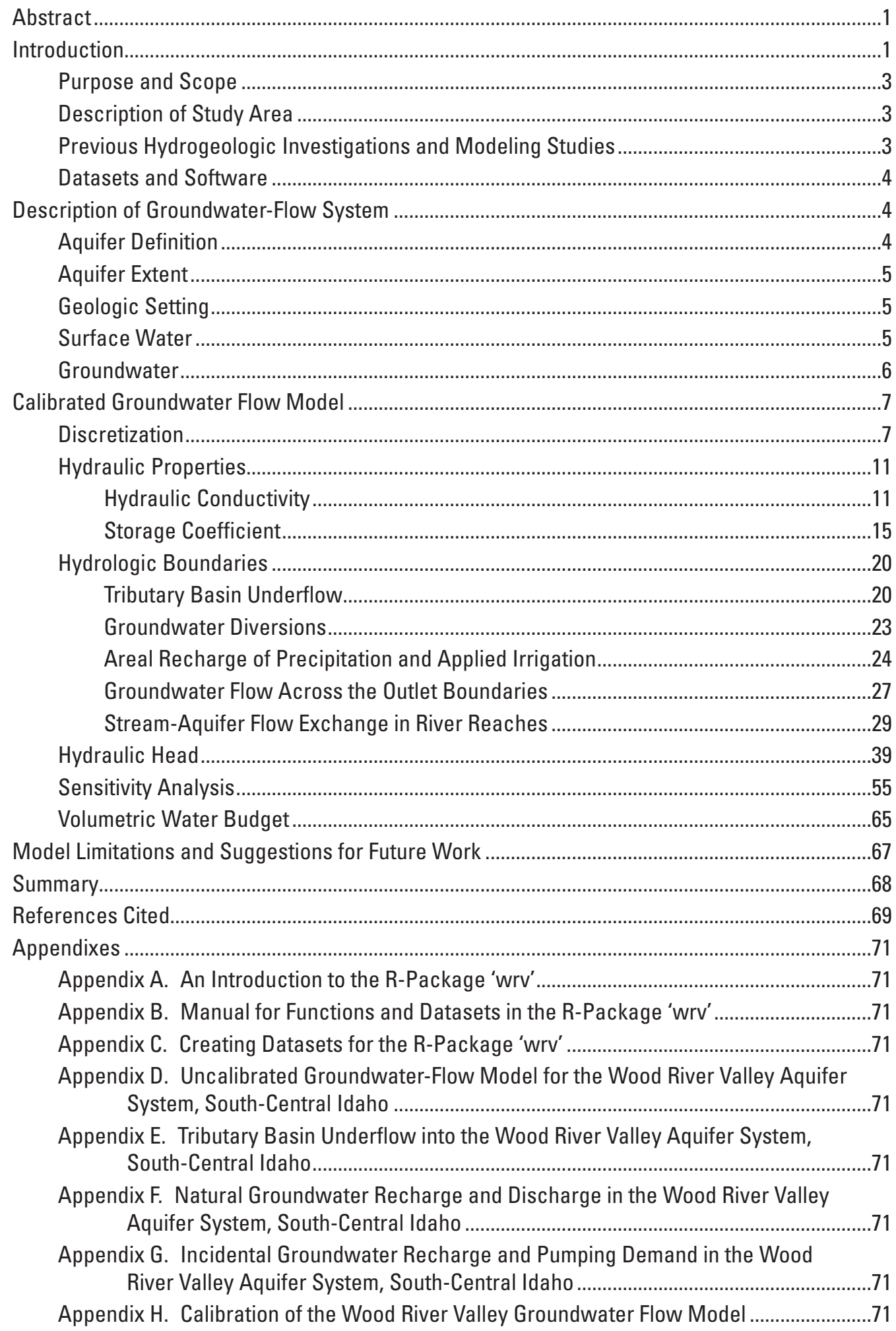




\section{Figures}

1. Map showing locations of communities, U.S. Geological Survey streamgages, and other features of the Wood River Valley, south-central Idaho.

2. Map showing model domain and locations of boundary-condition cell types in model layer 1, model layer 2, and model layer 3, Wood River Valley aquifer system, south-central Idaho.

3. Maps showing spatial distribution of the calibrated horizontal hydraulic conductivity in model layer 1, model layer 2, and model layer 3, Wood River Valley aquifer system, south-central Idaho

4. Vertical cross section of the calibrated horizontal hydraulic conductivity along the line of cross section A-A', Wood River Valley aquifer system, south-central Idaho ......15

5. Maps showing spatial distribution of the calibrated storage coefficient in model layer 1, model layer 2, and model layer 3, Wood River Valley aquifer system, south-central Idaho

6. Vertical cross section of the calibrated values of storage coefficient along transect line A-A' shown in figure 5, Wood River Valley, south-central Idaho.

7. Map showing spatial distribution of long-term mean tributary basin underflow in the Wood River Valley aquifer system, south-central Idaho...

8. Graph showing tributary basin underflow in the Wood River Valley aquifer system, south-central Idaho

9. Graph showing total groundwater withdrawals from production wells in the groundwater-flow model domain, Wood River Valley aquifer system, south-central Idaho

10. Map showing spatial distribution of calibrated irrigation efficiency in the groundwater-flow model domain, Wood River Valley aquifer system, south-central Idaho

11. Graph showing total areal recharge in the Wood River Valley aquifer system, south-central Idaho, 1995-2010.

12. Graph showing simulated groundwater discharge across the Stanton Crossing and Silver Creek outlet boundaries, Wood River Valley aquifer system, south-central Idaho, 1995-2010.

13. Map showing spatial distribution of the calibrated riverbed conductance in the groundwater-flow model domain, Wood River Valley aquifer system, south-central Idaho

14. Graph showing simulated stream-aquifer flow exchange in the groundwater-flow model domain, Wood River Valley aquifer system, south-central Idaho, 1995-2010 ......31

15. Graphs showing measured and simulated stream-aquifer flow exchange in the Big Wood River, near Ketchum to Hailey river reach, and Hailey to Stanton Crossing river reach, Wood River Valley aquifer system, south-central Idaho, 1995-2010.

16. Graph showing measured and simulated stream-aquifer flow exchange in the Willow Creek river reach, Wood River Valley aquifer system, south-central Idaho, 1995-2010

17. Graph showing measured and simulated stream-aquifer flow exchange along the Silver Creek, above Sportsman Access river reach; and Silver Creek, Sportsman Access to near Picabo river reach, Wood River Valley aquifer system, south-central Idaho, 1995-2010. 


\section{Figures-Continued}

18. Scatterplots showing mean stream-aquifer flow-exchange residuals along river reaches Big Wood River, near Ketchum to Hailey and Hailey to Stanton Crossing; Willow Creek; Silver Creek, above Sportsman Access; and Silver Creek, Sportsman Access to near Picabo, Wood River Valley aquifer system, south-central Idaho ............36

19. Scatterplots showing mean stream-aquifer flow-exchange ratio residuals for river subreaches during March, August, and October, Wood River Valley aquifer system, south-central Idaho.

20. Map showing simulated hydraulic heads representing the water-table surface in the Wood River Valley aquifer system, south-central Idaho, December 31, 2010

21. Maps showing simulated hydraulic heads representing the water-table surface in the areas north of Ketchum, south of Ketchum and north of Gimlet, south of Gimlet and north of Hailey, south of Hailey and north of Bellevue, and south of Bellevue, Wood River Valley aquifer system, south-central Idaho, December 2010

22. Vertical cross section of simulated hydraulic heads along transect line $A-A^{\prime}$, Wood River Valley aquifer system, south-central Idaho, December $2010 .$.

23. Map showing simulated and measured water-table contours, southern part of the Wood River Valley, south-central Idaho, October 2006

24. Scatterplots of water-table residuals in U.S. Geological Survey groundwatermonitoring network wells, Geolocated driller wells, Public Land Survey Systemlocated driller wells, and two of the Sun Valley Water and Sewer District production wells and The Nature Conservancy groundwater-monitoring network wells, Wood River Valley aquifer system, south-central Idaho, 1995-2010

25. Map showing spatial distribution of average hydraulic head differences between measured and simulated values (residuals) in U.S. Geological Survey groundwater-monitoring network wells, Wood River Valley aquifer system, south-central Idaho, 1995-2010

26. Map showing spatial distribution of average hydraulic head differences between measured and simulated values (residuals) in the geolocated driller wells, Wood River Valley aquifer system, south-central Idaho, 1995-2010

27. Map showing spatial distribution of average hydraulic head differences between simulated and measured values (residuals) in the Public Land Survey System-located driller wells, Wood River Valley aquifer system, south-central Idaho, 1995-2010.

28. Map showing spatial distribution of average hydraulic head differences between measured and simulated values (residuals) in two production wells (the two most northern well sites on the map) of the Sun Valley Water and Sewer District and wells in The Nature Conservancy groundwater-monitoring network, Wood River Valley aquifer system, south-central Idaho, 1995-2010

29. Graphs showing measured and simulated groundwater-level hydrographs for U.S. Geological Survey wells 01S 18E 14AAB1, and 01N 18E 01DAA2, Wood River Valley aquifer system, south-central Idaho, 1995-2010.

30. Graphs showing measured and simulated groundwater-level hydrographs for Sun Valley Water and Sewer District wells 04N 18E 07ADD, and 04N 18E 19DCDC1, Wood River Valley aquifer system, south-central Idaho, 1995-2010 


\section{Figures-Continued}

31. Graphs showing measured and simulated groundwater-level hydrographs for The Nature Conservancy wells 02N 18E 09BCD1, and 02N 18E 35ACC1, Wood River

Valley, south-central Idaho, 1995-2010.

32. Graphs showing relative composite sensitivities of adjusted parameters horizontal hydraulic conductivity, storage coefficient, irrigation efficiency, riverbed conductance, drain conductance, and tributary underflow scalar, used in Wood River Valley groundwater-flow model, south-central Idaho

33. Graph showing water-budget components by year, including annual change in storage, for the entire model-simulation period, 1995-2010, Wood River Valley aquifer system, south-central Idaho

\section{Tables}

Table 1. Descriptive statistics for the calibrated values of horizontal hydraulic conductivity and specified for each hydrogeologic zone, Wood River Valley aquifer system, south-central Idaho

Table 2. Descriptive statistics for the calibrated storage coefficient and specified for each hydrogeologic zone, Wood River Valley aquifer system, south-central Idaho

Table 3. Long-term mean tributary basin underflow in the Wood River Valley aquifer system, south-central Idaho

Table 4. Irrigation efficiencies applied to each irrigation entity in the groundwater-flow model domain, Wood River Valley aquifer system, south-central Idaho

Table 5. Drain conductance and elevation threshold for groundwater outlet boundaries, Wood

River Valley aquifer system, south-central Idaho

Table 6. Calibrated riverbed conductance in river subreaches of the Wood River Valley aquifer system, south-central Idaho

Table 7. Descriptive statistics for the residual of stream-aquifer flow exchange along river reaches in the Wood River Valley aquifer system, south-central Idaho.

Table 8. Estimates and relative composite sensitivities of parameters varied during the calibration process for the Wood River Valley groundwater-flow model, southcentral Idaho

Table 9. Water budget specified as volumetric flow rates averaged over the 1995-2010, Wood River Valley aquifer system, south-central Idaho. 


\section{Conversion Factors}

Inch/Pound to International System of Units

\begin{tabular}{ccl}
\hline Multiply & By & To obtain \\
\hline & Flow rate & \\
\hline acre-foot per year (acre-ft/yr) & 1,233 & cubic meter per year $\left(\mathrm{m}^{3} / \mathrm{yr}\right)$ \\
acre-foot per year (acre-ft/yr) & 0.001233 & cubic hectometer per year $\left(\mathrm{hm}^{3} / \mathrm{yr}\right)$ \\
\hline
\end{tabular}

International System of Units to Inch/Pound

\begin{tabular}{|c|c|c|}
\hline Multiply & By & To obtain \\
\hline \multicolumn{3}{|c|}{ Length } \\
\hline meter (m) & 3.281 & foot $(\mathrm{ft})$ \\
\hline kilometer (km) & 0.6214 & mile (mi) \\
\hline \multicolumn{3}{|c|}{ Area } \\
\hline square kilometer $\left(\mathrm{km}^{2}\right)$ & 247.1 & acre \\
\hline square kilometer $\left(\mathrm{km}^{2}\right)$ & 0.3861 & square mile $\left(\mathrm{mi}^{2}\right)$ \\
\hline \multicolumn{3}{|c|}{ Volume } \\
\hline cubic meter $\left(\mathrm{m}^{3}\right)$ & 6.290 & barrel (petroleum, 1 barrel = 42 gal) \\
\hline cubic meter $\left(\mathrm{m}^{3}\right)$ & 264.2 & gallon (gal) \\
\hline cubic meter $\left(\mathrm{m}^{3}\right)$ & 0.0002642 & million gallons (Mgal) \\
\hline cubic meter $\left(\mathrm{m}^{3}\right)$ & 35.31 & cubic foot $\left(\mathrm{ft}^{3}\right)$ \\
\hline cubic meter $\left(\mathrm{m}^{3}\right)$ & 0.0008107 & acre-foot (acre-ft) \\
\hline \multicolumn{3}{|c|}{ Flow rate } \\
\hline meter per day (m/d) & 3.281 & foot per day (ft/d) \\
\hline cubic meter per day (m³/d) & 0.0004087 & cubic foot per second $\left(\mathrm{ft}^{3} / \mathrm{s}\right)$ \\
\hline cubic meter per day (m³/d) & 35.31 & cubic foot per day $\left(\mathrm{ft}^{3} / \mathrm{d}\right)$ \\
\hline cubic meter per day (m³/d) & 264.2 & gallon per day (gal/d) \\
\hline cubic meter per day $\left(\mathrm{m}^{3} / \mathrm{d}\right)$ & 0.2961 & acre-foot per year $(\mathrm{km})$ \\
\hline \multicolumn{3}{|c|}{ Hydraulic conductivity } \\
\hline meter per day (m/d) & 3.281 & foot per day (ft/d) \\
\hline \multicolumn{3}{|c|}{ Riverbed conductance } \\
\hline meter squared per day $\left(\mathrm{m}^{2} / \mathrm{d}\right)$ & 10.76 & foot squared per day $\left(\mathrm{ft}^{2} / \mathrm{d}\right)$ \\
\hline
\end{tabular}




\section{Datums}

Vertical coordinate information is referenced to the North American Vertical Datum of 1988 (NAVD 88).

Horizontal coordinate information is referenced to North American Datum of 1983 (NAD 83).

Elevation, as used in this document, refers to distance above the vertical datum.

\section{Abbreviations}

BWR Upper Confluence of the Big Wood River and the North Fork Big Wood River

HK horizontal hydraulic conductivity

IDWR Idaho Department of Water Resources

K hydraulic conductivity

MAE mean absolute error

PLSS Public Land Survey System

SC confined storage coefficient

SD standard deviation

SI seasonal scaling index

SVWSD Sun Valley Water and Sewer District

TNC The Nature Conservancy

USGS U.S. Geological Survey

WRV Wood River Valley 


\title{
Groundwater-Flow Model for the Wood River Valley Aquifer System, South-Central Idaho
}

\author{
By Jason C. Fisher', James R. Bartolino', Allan H. Wylie², Jennifer Sukow², and Michael McVay²
}

\section{Abstract}

A three-dimensional numerical model of groundwater flow was developed for the Wood River Valley (WRV) aquifer system, Idaho, to evaluate groundwater and surface-water availability at the regional scale. This mountain valley is located in Blaine County and has a drainage area of about 2,300 square kilometers (888 square miles). The model described in this report can serve as a tool for water-rights administration and water-resource management and planning. The model was completed with support from the Idaho Department of Water Resources, and is part of an ongoing U.S. Geological Survey effort to characterize the groundwater resources of the WRV. A highly reproducible approach was taken for constructing the WRV groundwater-flow model. The collection of datasets, source code, and processing instructions used to construct and analyze the model was distributed as an R statistical-computing and graphics package.

Flow in the WRV aquifer was simulated using the MODFLOW-USG groundwater flow model. The transient flow model simulates groundwater flow between 1995 and 2010. The model uses a 100-meter (328-feet) uniform grid spacing with 54,922 active model cells distributed over three model layers. A confining unit in the south-central part of the Bellevue fan necessitated the use of a multi-layer model. Specified-flow boundaries were used to simulate the groundwater inflows from each of the major tributary basins (also known as tributary basin underflow) and the areal recharge of precipitation and applied irrigation. Head-dependent flow boundaries were used to simulate the stream-aquifer flow exchange in river reaches and the groundwater discharge at the outlet boundaries of Stanton Crossing and Silver Creek. The model was calibrated by adjusting aquifer hydraulic properties to match simulated and measured water levels and stream-aquifer flow exchange, using the parameter-estimation program PEST. The model reasonably simulated the measured water-table elevation, orientation, and gradients. Stream-aquifer flow exchange along river reaches also was reasonably simulated by the model.

${ }^{1}$ U.S. Geological Survey.

${ }^{2}$ Idaho Department of Water Resources.
Inflow into the WRV aquifer system originates from three sources (from largest to smallest):

1. Streamflow loss from the Big Wood River and Silver Creek,

2. Areal recharge of precipitation and applied irrigation, and

3. Tributary basin underflow.

Outflow from the WRV aquifer system originates from five sources (from largest to smallest):

1. Aquifer discharge into the Big Wood River and Silver Creek,

2. Production-well pumping,

3. Discharge across the water table into the vadose zone,

4. Subsurface outflow beneath Silver Creek near Picabo, and

5. Subsurface outflow beneath the Big Wood River near Stanton Crossing.

Temporal changes in aquifer storage are most affected by areal recharge and groundwater pumping, and also contribute to changes in streamflow gains.

\section{Introduction}

The population of Blaine County in south-central Idaho nearly quadrupled-from about 5,700 to 21,000 peoplebetween 1970 and 2013 (Forstall, 1995; U.S. Census Bureau, 2014). In addition to permanent residents, thousands of people visit Blaine County annually for winter and summer recreation. Most population growth and recreational uses are in the northernmost part of the county in the Wood River Valley (WRV) (fig. 1). The majority of the valley population depends on groundwater for its domestic water supply, either from privately owned or municipal-supply wells. Groundwater also is used for commercial, industrial, and irrigation purposes; surface water is used for recreation and irrigation. The extensive interaction between groundwater and surface water in the valley was recognized in the early 20th century (Chapman, 1921). 
Groundwater-Flow Model for the Wood River Valley Aquifer System, South-Central Idaho

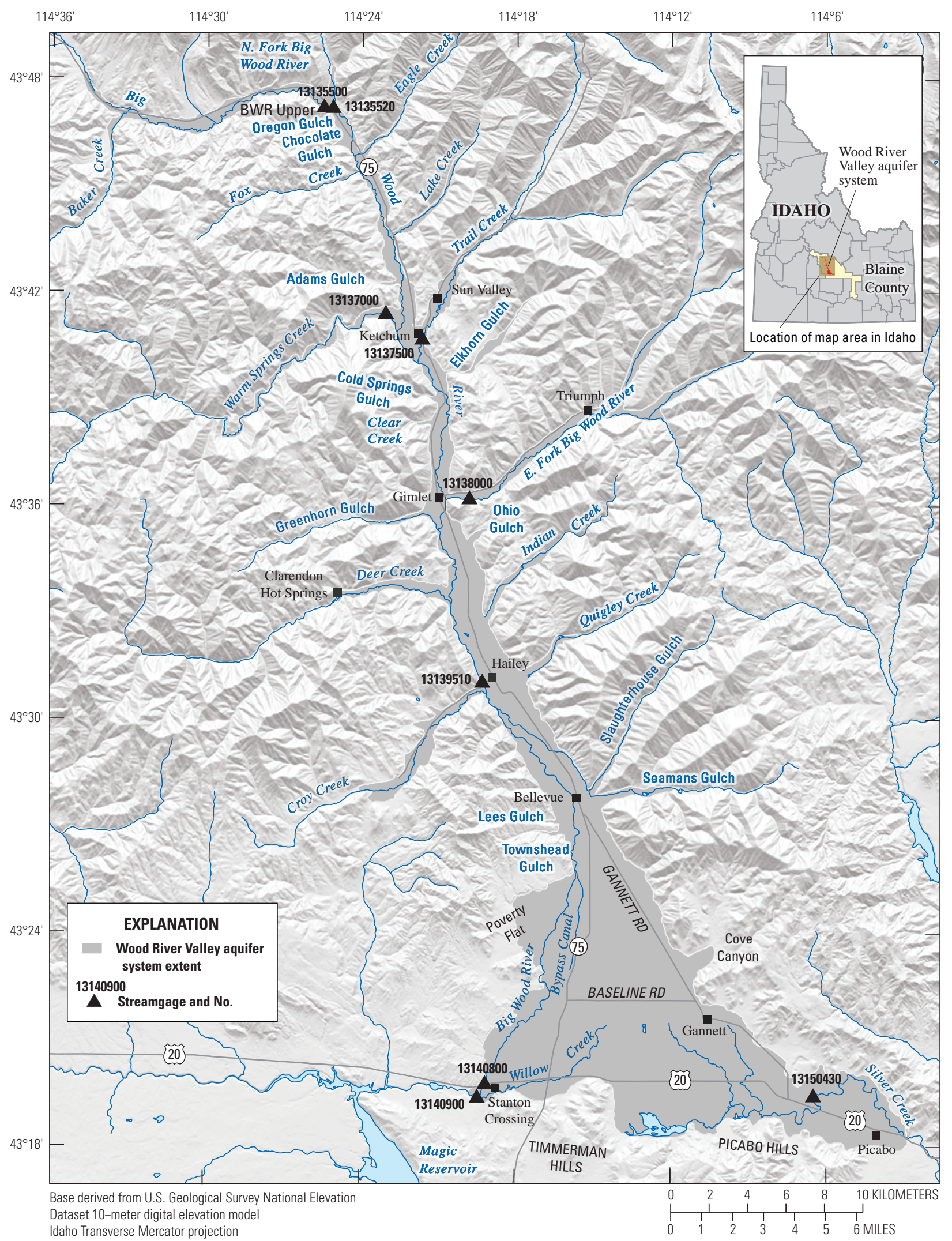

Figure 1. Locations of communities, U.S. Geological Survey streamgages, and other features of the Wood River Valley, south-central Idaho. 
In 2012, the U.S. Geological Survey (USGS), in cooperation with the Idaho Department of Water Resources (IDWR), began work on development and calibration of a numerical groundwater-flow model to advance the basic understanding of the aquifer system. Ultimately the model could be used to examine human development and climatic effects on the groundwater system and its interaction with the Big Wood River caused by changes in water use and groundwater recharge and discharge. Groundwater-flow models have become the most commonly used tool for conjunctive administration of groundwater and surfacewater rights, and the groundwater-flow model of the WRV aquifer system may serve as a tool for this purpose as well as water-resource management and planning.

\section{Purpose and Scope}

This report describes the development and calibration of a numerical model to simulate groundwater flow in the WRV aquifer system. The model was constructed using existing data and interpretations, as well as new data and interpretations conducted specifically for the development and calibration of the model. Steps in model development described in this report include the representation of the:

1. Hydrogeologic framework,

2. Model extent,

3. Model boundary conditions,

4. Inflows to and outflows from the aquifer system, and

5. Model calibration using parameter-estimation techniques to adjust model parameters (such as hydraulic conductivity and tributary basin underflow) to match measured and simulated values (such as groundwater levels and stream discharge).

The model is intended to simulate potential anthropogenic and climatic effects on groundwater and surface-water resources. It can be used as a tool for water-rights administration and water-resource management and planning. Because of the regional scale of the model and the commensurate level of detail, the model is most appropriate for the simulation and analysis of aquifer-wide effects rather than localized effects.

\section{Description of Study Area}

The WRV of south-central Idaho extends from Galena Summit (not shown) $32 \mathrm{~km}$ northwest of Ketchum, at the head of the Big Wood River Basin north of the study area, southward to the Timmerman and Picabo Hills (fig. 1). This mountain valley has a drainage area of about $2,300 \mathrm{~km}^{2}$ $\left(888 \mathrm{mi}^{2}\right)$ (Skinner and others, table 7). The valley can be separated into upper and lower parts along an east-west line immediately south of Bellevue. The upper valley is narrow, broadening downstream to a maximum width of $3.2 \mathrm{~km}$
(2 mi), and the lower valley opens into a triangular alluvial fan (the Bellevue fan) about $14.5 \mathrm{~km}(9 \mathrm{mi})$ wide at its southern end. The study area of this report is the part of the WRV aquifer system that extends from Baker Creek southward to the Timmerman and Picabo Hills, including parts of tributary valleys with producing wells (fig. 1).

The floor of the WRV is relatively flat, and land-surface elevations range from about $2,100 \mathrm{~m}(6,800 \mathrm{ft})$ at the northern boundary of the WRV aquifer system (Bartolino and Adkins, 2012) near the confluence of the Big Wood River with Baker Creek to about 1,500 m (4,800 ft) at the southeastern boundary near Picabo and the southwestern boundary at Stanton Crossing (fig. 1). Numerous tributary canyons intersect the valley, the largest of which are those of the North Fork Big Wood River, Warm Springs Creek, Trail Creek, the East Fork Big Wood River, Deer Creek, and Croy Creek (fig. 1). The main valley and the tributary canyons have steep sides and are surrounded by highlands with peaks at elevations of more than 3,300 m (11,000 ft).

In addition to their different physiographic characteristics, the upper and lower valleys also differ in land use. The upper WRV is more developed and contains the incorporated communities of Sun Valley, Ketchum, Hailey, and Bellevue (fig. 1). Land use in the upper valley is predominantly residential with many large homes situated on landscaped acreage; the main source of water in the upper valley is groundwater. The lower WRV is dominated by farms and ranches that are irrigated by groundwater and diverted surface water, and contains the small communities of Gannett and Picabo (fig. 1). Although some of the tributary canyons in the upper valley, such as Trail and Warm Springs Creeks, have supported development for more than 70 years, more recent development has expanded into the other tributary canyons of the valley. Three wastewater-treatment plants in the study area discharge to the Big Wood River, another plant uses land application for treated wastewater, and many homes rely on septic systems for wastewater disposal. Other features of the study area, including climate, are described in Skinner and others (2007), Bartolino (2009), Bartolino and Adkins (2012), Hopkins and Bartolino (2013), and Bartolino (2014).

\section{Previous Hydrogeologic Investigations and Modeling Studies}

Bartolino (2014) measured streamflow and groundwater levels at multiple sites in the WRV. Streamflow was measured to estimate seepage rates between streams and the underlying aquifer in August 2012, October 2012, and March 2013. Groundwater levels were measured in October 2012 in 93 wells completed in the WRV aquifer system to compile maps of October 2012 conditions and changes between the October 2006 and October 2012 conditions in the unconfined and confined aquifers. Bartolino (2014) also described previously published studies relating to surface-water flow, seepage measurements, and groundwater-level measurements. 
Groundwater-Flow Model for the Wood River Valley Aquifer System, South-Central Idaho

Bartolino and Adkins (2012) described the hydrogeologic framework of the WRV aquifer system and summarized previous work on the geology and hydrogeology of the area. Bartolino (2009) developed groundwater budgets for the WRV aquifer system for three selected time periods - average conditions for the 10-year period 1995-2004 and for the single years of 1995 and 2001 — and listed previously published studies with volumetric water budgets for all or part of the WRV.

Brockway and Grover (1978) developed the first groundwater-flow model of the WRV aquifer system using a two-dimensional finite-difference model code developed by de Sonneville (1972) and Newton (1978). Because the model code could only represent a single layer, separate models were developed for the confined and unconfined aquifers. Simulated leakage from the upper unconfined aquifer was applied as groundwater recharge to the lower confined aquifer. The model area encompassed the Bellevue fan area south of Bellevue and a uniform, square grid was specified with 23 rows, 29 columns, and a model cell size of $805 \mathrm{~m}(0.5 \mathrm{mi})$. The transient model used weekly time steps and was calibrated using data collected from May 1975 to July 1976. Numerous "future-conditions" scenarios were simulated with varying simulation periods.

Following single and multi-year drought conditions between 1977 and 1992 that resulted in decreased streamflow and a fish kill in Silver Creek, Wetzstein and others (1999) of the Idaho Water Resources Institute developed a groundwater-flow model of the Bellevue fan area south of Hailey using the USGS MODFLOW computer code of McDonald and Harbaugh (1988). The model was completed in two phases-Brockway and Kahlown (1994) compiled data for the model and Wetzstein and others (1999) described the model development. The model contained three layers and 355 active cells (in the uppermost layer) in 34 columns and 35 rows in a uniform, square grid of $805-\mathrm{m}$ ( 0.5 -mi) cells. The transient model-calibration period was April 1993-April 1994; each of the 24 time steps was 15.2 days. Numerous "future-conditions" scenarios were simulated with varying simulation periods.

Loinaz (2013) constructed a "catchment scale integrated hydrological model" of the WRV downstream of Hailey "coupled to a stream temperature model of the Silver Creek Basin” using the MIKE SHE/MIKE 11 models (DHI Group, 2014a, 2014b). The hydrological model was calibrated to the 2003-09 period and the temperature model was calibrated to the 2007-09 period. Management scenarios were simulated for changes in land use, water use, river morphology (sedimentation), and stream-bank vegetation; a final scenario examined the effects of returning the Silver Creek drainage basin to natural conditions.

Consulting firms have developed numerous proprietary groundwater-flow models of parts of the WRV for the evaluation of localized hydrologic conditions. These models have been applied to such uses as water-right transfers and land-development applications. The groundwater-flow model described in the current report differs from previous published models in that it extends north of Hailey and includes most of the Wood River Valley aquifer system (fig. 1).

\section{Datasets and Software}

Using a software development methodology, a highly reproducible approach was taken for developing the WRV groundwater-flow model. Model reproducibility requires archiving and documenting all datasets and computer source code used to pre- and post-process the model—an undertaking made easier by the advances in open source software, open file formats, and cloud computing. The collection of datasets, source code, and processing instructions used to construct and analyze the uncalibrated model was placed in a software package referred to as $\mathbf{~ w r v}$. The $\mathbf{~ w r v}$ package is an extension of the R-programming language (R Core Team, 2014) that allows for easy, transparent, and cross-platform distribution of its content by enforcing a set of formal format standards. An introduction to the wrv package is provided in appendix A; a manual describing package datasets and processing programs (also known as functions in $\mathrm{R}$ ) is provided in appendix B. Finally, processing steps for creating wrv-package datasets are described in appendix C. MODFLOW-USG, a USGS computer program for simulating three-dimensional, steadystate and transient groundwater flow (Panday and others, 2013), is included with the $\mathbf{w r v}$ package and used to simulate flow in the WRV aquifer system. The groundwater-flow model was calibrated using PEST, a parameter estimation software suite developed by Doherty (2005). PEST is not included in the wrv package.

\section{Description of Groundwater-Flow System}

\section{Aquifer Definition}

This report uses "Wood River Valley aquifer system" as defined by Skinner and others (2007, p. 4):

“...the aquifer system of the Wood River Valley is here informally named the Wood River Valley aquifer system. It includes the Quaternary sediments of the Wood River Valley and its tributaries and locally, underlying igneous, sedimentary, or metamorphic rocks where they are hydraulically connected and used for water supply. The Wood River Valley aquifer system consists of a single unconfined aquifer and an underlying confined aquifer present south of Baseline Road." 
Although this definition implicitly includes the Quaternary-age basalts of the Gannett and Picabo area, Bartolino and Adkins (2012, p. 6) explicitly included these basalts as part of the aquifer system. They also noted that, although the consolidated pre-Quaternary rocks provide water to wells and springs (primarily in tributary canyons),

"it is unclear to what extent these rocks are hydraulically connected to the Quaternary-age sediments and basalts that form the bulk of the Wood River Valley aquifer system."

Skinner and others (2007) and Bartolino (2009) also mentioned these pre-Quaternary consolidated rocks as a source of water but did not speculate on the degree of hydraulic connection with the main aquifer system.

\section{Aquifer Extent}

The areal extent of the WRV aquifer system, as used in this report, slightly modifies that of Bartolino and Adkins (2012) that, in turn, was a slight modification of that in Skinner and others (2007). Skinner and others (2007) defined the lateral boundary of the WRV aquifer system as the contact between unconsolidated alluvium (or Quaternary basalt) and consolidated bedrock. In most of the valley, this contact is indicated by an abrupt change in slope from valley sides to the valley floor.

Skinner and others (2007, p. 14) described the methodology used to define their lateral model boundary thus:

"The study area boundary was defined by using a [digital-elevation model] converted to a slope model to determine the transition from the adjacent bedrock hills (high slope values) to the flat portions of the valley filled with unconsolidated sediment (low slope values). This transition represents the approximate location of the boundary between the unconfined aquifer and the adjacent bedrock in the tributary canyons and the main valley."

Apart from minor boundary adjustments to correct anomalies created by the slope model of Skinner and others (2007), Bartolino and Adkins (2012, p. 6) modified the boundary:

"It has been extended farther up several tributary canyons, extended up the Big Wood River to include a number of wells near the mouth of Baker Creek, expanded to include the western side of the Poverty Flat area, and extended slightly downstream of Stanton Crossing and Picabo.”

The model presented in this report incorporates further minor adjustments to the lateral boundary to correct additional anomalies in the Skinner and others (2007) boundary. Additionally, the western side of the Poverty Flat area, defined by older Quaternary gravel terrace deposits above a scarp "60-75 feet above the present floodplain" (Breckenridge and
Othberg, 2006) was excluded from the current model domain because a drillers' log indicates that granite of the Idaho Batholith is the main water-bearing unit and not alluvium.

\section{Geologic Setting}

The WRV aquifer system was formed during the Quaternary Period by “a sequence of deposition and erosion by the Big Wood River, basalt flows in the Picabo and Stanton Crossing areas, and glaciation in the upper Big Wood River drainage and tributary canyons" (Bartolino and Adkins, 2012, p. 15). Broadly, the aquifer system was formed by three episodes. First, early Pleistocene glaciation in the mountains surrounding the WRV deposited a broad alluvial fan on top of older, relatively impermeable bedrock. This alluvial fan, which is referred to as the Bellevue fan, is located in the lower valley with its apex at Bellevue. Flow of the ancestral Big Wood River exited the valley either east or west of the ancestral Timmerman and Picabo Hills. Second, a series of lava flows erupted, which dammed and diverted the river between the eastern and western sides of the Timmerman and Picabo Hills, possibly multiple times, resulting in a sequence of fluvial and lacustrine sediments of some thickness on the Bellevue fan that interfinger with basalts to the southeast and southwest. Finally, a combination of deposition and erosion allowed the Big Wood River to establish its current through-flowing course to the west. Changes in climate during glacial episodes varied the texture and amount of sediment, as well as shifted some settings between deposition and erosion. These events are thus responsible for the hydrogeologic units that form the aquifer system and explain why they are heterogeneous within units and why the boundaries between units are often indistinct. The three main components of the aquifer system are thus composed of glacial outwash sediment and basalts that form the unconfined and confined aquifers and finegrained lacustrine sediment that forms the confining unit. The hydrogeologic framework of the WRV aquifer system by Bartolino and Adkins (2012) contains a more detailed geologic history and setting of the study area.

\section{Surface Water}

The Big Wood River and its tributaries drain most of the WRV; the southeastern part of the Bellevue fan is drained by Silver Creek, a tributary to the Little Wood River. The Big Wood and Little Wood Rivers meet near Gooding, about $56 \mathrm{~km}$ (35 mi) southwest of the study area, where they join to form the Malad River, a tributary to the Snake River. The Big Wood River originates near Galena Summit, about $32 \mathrm{~km}$ (20 mi) northwest of Ketchum, gaining flow from numerous perennial and ephemeral tributaries as it meanders across the narrow upper valley. At Bellevue, the channel follows the western side of the Bellevue fan (although flow through part of this reach is ephemeral), and exits the valley at the Big 
Groundwater-Flow Model for the Wood River Valley Aquifer System, South-Central Idaho

Wood River at the Stanton Crossing near Bellevue streamgage (13140800; fig. 1). The installation of this streamgage (13140800) occurred in September 1996 and coincided with the closure of the downstream (about $2 \mathrm{~km}$ [1 mi]) Big Wood River near Bellevue streamgage (13141000).

The Big Wood River in the study area can be divided into two segments. The upper reach between the Big Wood River Near Ketchum streamgage (13135500) and the Big Wood River at Hailey streamgage (13139510) generally gains flow, and the lower reach between the Hailey streamgage and the Big Wood River at Stanton Crossing near Bellevue streamgage (13140800) generally loses flow. The lower part of this reach however is fed by springs and seeps. Willow Creek, a spring-fed tributary, joins the Big Wood River just downstream of the Stanton Crossing streamgage. Within the shorter reaches of these two segments, seepage to or from the stream may either differ in direction and (or) magnitude or be indeterminate because of measurement uncertainty; in some reaches, seepage direction may reverse seasonally (Bartolino, 2014).

Most of the streams in the tributary canyons to the Big Wood River provide inflow to the Big Wood River primarily in response to precipitation or snowmelt; however, the North Fork Big Wood River, Warm Springs Creek, Trail Creek, and the East Fork Big Wood River provide substantial flow into the Big Wood River year-round. Streams in some of the smaller tributary canyons are perennial in their upper reaches, and some of this water likely infiltrates directly into the aquifer system, or reaches the Big Wood River by subsurface flow through riverbed gravels. Except during flooding, streamflow in Indian Creek and several smaller tributaries is diverted into canals. Silver Creek and its tributaries originate at springs on the Bellevue fan. Silver Creek flows southeast out of the valley near Picabo (fig. 1).

A well-developed network of irrigation canals and drains is present throughout the study area; most of the WRV was under irrigation by 1900 (Jones, 1952), with the oldest water rights in the valley dating to 1880 . The diversions and return flows between the irrigation system and the Big Wood River, as well as the exchange of water between the canals, drains, and streams and the underlying unconfined aquifer, complicate the interpretation of streamflow gains and losses. Eight canals carry most of the surface water diverted from the Big Wood River for irrigation (from largest to smallest based on 1995 diversions): District 45, Baseline, Hiawatha, Bypass Extension, Glendale, Graff, Cove, and Bannon. The Kilpatrick Ditch and numerous smaller diversions deliver water from the Big Wood River, Silver Creek, and tributaries. Water District 37 oversees water distribution within the Big Wood River Basin and Water District 37M oversees water distribution within the Silver Creek and Little Wood River Basin. In 2014, Water District 37M was combined with Water District 37. Water District 37 maintains diversion records for surface-water diversions from April through September although unrecorded diversions commonly take place in
October. The irrigation season is from April through October; however, the October diversions are not recorded.

In 1920, the Baseline Bypass Canal was constructed to divert streamflow around an ephemeral section of the Big Wood river known as the "Dry Bed" to speed the passage of water to downstream sections of the river and to reduce streamflow losses (Chapman, 1921). During the late summer and early autumn, all flow remaining in the Big Wood River at Glendale Bridge is diverted into the Baseline Bypass Canal. Water in the Bypass Canal is delivered for irrigation or returned to the Big Wood River immediately above a series of springs that supply the base flow at the Big Wood River at Stanton Crossing near Bellevue streamgage (13140800; fig. 1).

For much of the year, Willow and Silver Creeks are fed entirely from springs and seeps in the southeastern part of the Bellevue fan. Snowmelt runoff contributes some flow seasonally. Silver Creek also is known to receive water from drains, diversions from the Big Wood River, and exchange wells. Exchange wells pump groundwater into a river or stream so that an equivalent amount of water can be diverted at a downstream location. The uppermost reaches of each of the Silver Creek tributaries gain flow; however, lower reaches of the tributaries and Silver Creek may lose flow (sometimes reversing [gaining] seasonally) (Moreland, 1977).

\section{Groundwater}

The WRV aquifer system comprises a single unconfined aquifer that underlies the entire valley, an underlying confined aquifer that is present only in the southern Bellevue fan (generally to the south of Baseline Road; fig. 1), and a confining unit separating the two aquifers. The aquifer system consists primarily of Quaternary sediments of the WRV, although Quaternary basalts with interbedded sediments constitute the primary source of groundwater in the southeastern Bellevue fan.

The confined aquifer is separated from the overlying unconfined aquifer by a confining unit composed of fine-grained lacustrine deposits. This confining unit thickens toward the south and, generally, as land-surface elevation declines in the same direction, the potentiometric surface of the confined aquifer rises above land surface and some wells flow under artesian pressure. South of Gannett, near the westernmost extent of Quaternary basalt, the confining unit fingers out and the aquifer system becomes wholly unconfined again (appendix D, fig. D7).

Depth to groundwater in the upper valley commonly is less than $3 \mathrm{~m} \mathrm{(10} \mathrm{ft),} \mathrm{increasing} \mathrm{to} \mathrm{about} 27 \mathrm{~m} \mathrm{(90} \mathrm{ft)} \mathrm{to}$ the south. Depth to groundwater in wells completed in the unconfined aquifer in the lower (or southern) part of the valley ranges from less than $3 \mathrm{~m}(10 \mathrm{ft})$ to about $46 \mathrm{~m}(150 \mathrm{ft})$. Wells completed in the confined aquifer are under artesian pressure and flow where the potentiometric surface is above land surface. 
Hydraulic properties of the aquifers were estimated in previous studies. Published estimates of transmissivity, a measure of how much groundwater can be transmitted horizontally, were published for five multiple-well aquifer tests in and near the boundary of the WRV aquifer system (Smith, 1959; Moreland, 1977; Frenzel, 1989). Additional transmissivity estimates were made by Moreland (1977), Frenzel (1989), and Bartolino and Adkins (2012) using the specific capacity derived from well-performance tests recorded on drillers' logs. Bartolino and Adkins (2012) estimated 81 values of hydraulic conductivity based on the transmissivity estimates from these studies to map the distribution of hydraulic conductivity and estimate its statistical properties for the unconfined and confined aquifers.

\section{Calibrated Groundwater Flow Model}

Groundwater flow in the WRV aquifer system is simulated using MODFLOW-USG, a numerical model for simulating three-dimensional, steady-state and transient groundwater flow (Panday and others, 2013). The development of the uncalibrated groundwater-flow model, using initial estimates for the aquifer's hydraulic properties, is described in appendix D. Additional details on the construction of the uncalibrated boundary conditions are provided in appendix E for tributary basin underflow, appendix $\mathrm{F}$ for natural groundwater recharge and discharge, and appendix $\mathrm{G}$ for incidental groundwater recharge and pumping demand. Model calibration is the process of adjusting selected model parameter values within an expected range to minimize the differences between measured and simulated values within an acceptable tolerance or error. The WRV groundwater-flow model was calibrated using PEST, a non-linear, model-independent parameter estimation program (Doherty, 2005). The calibration process started with the uncalibrated model (appendix D). A detailed discussion of the calibration setup for the WRV groundwater-flow model (such as, which parameters were adjusted through the calibration process, and the set of observations used to infer these parameters) is provided in appendix $\mathrm{H}$. An overview of the calibrated groundwater-flow model and an evaluation of its goodness of fit (that is, how well the model performs at simulating observed hydrologic conditions) is provided in the remainder of this report.

\section{Discretization}

The model domain covers $242 \mathrm{~km}^{2}\left(94 \mathrm{mi}^{2}\right)$, or 88 percent of the WRV aquifer system area (fig. 1). An inability to obtain continuous grid coverage at an adequate resolution in the upper parts of the narrow and steep tributary canyons of the WRV resulted in their exclusion from the model domain. The model domain is spatially discretized with a horizontal grid of 299 columns and 542 rows, and is vertically discretized into three model layers (fig. 2). The number of active cells varies for each model layer with 24,242 in layer 1, 15,721 in layer 2, and 14,959 in layer 3. Each cell is $100 \mathrm{~m}(328 \mathrm{ft})$ square on the horizontal. Cell thickness is variable and ranges from 1 to $74 \mathrm{~m}$, with a mean and standard deviation (SD) of 20 and $15 \mathrm{~m}$, respectively. The grid is aligned to the cardinal directions (running north-south and east-west). The northwestern corner of the grid (or model origin) is located at the Idaho Transverse Mercator projected coordinate 2,466,200 m east and 1,398,339 m north.

The top of model layer 1 is specified at land surface and has a topographic relief of $477 \mathrm{~m}$ (1,565 ft). Model layers 2 and 3 are only active in the southern part of the model area, and extends north to about Hailey. Model layer 2 is relatively thin in comparison to the other layers, with a maximum thickness of $5 \mathrm{~m}$ (16 ft). Part of model layer 2 is used to represent a confining unit or low-permeability unit that separates the unconfined aquifer above (model layer 1) from the confined aquifer below (model layer 3 ). The bottom of model layer 3 is specified at bedrock. The thickness of the model domain varies, reaching a maximum depth of $109 \mathrm{~m}$ (357 ft) near the center of the Bellevue fan.

Groundwater flow in the WRV aquifer system is simulated for January 1995-December 2010, a 16-year duration. The interval of temporal discretization is the "time step". Individual, sequential time steps are grouped into "stress periods," in which time-dependent input data can be changed every stress period (Harbaugh and others, 2000, p. 8). Individual stress periods in a simulation can be either steady-state or transient.

The first stress period is specified as steady state and is used only to generate starting heads approximating conditions at the beginning of calendar year 1995. Steady-state flow was simulated using average groundwater recharge and discharge values from April 2004 through March 2005, because hydrologic conditions generally were similar to the period preceding the beginning of 1995 . All subsequent stress periods are transient. The transient stress periods simulate groundwater flow from 1995 through 2010. This simulation period is divided into 192 stress periods of 1 month each; a stress period comprises four time steps of equal duration (each time step is about 1 week in duration). A preliminary sensitivity analysis to changes in the number of time steps indicated that more than four time steps per stress period did not yield significant simulation differences or mass balance errors. The length of each stress period is dependent on the number of days in the corresponding month and date of year.

A 3-year "warm-up" period is included in the simulation to reduce uncertainties associated with the dissipation of transient effects arising from inaccuracies inherent in the model initialization. The transient variability of stresses on the aquifer prior to January 1995 are not represented in the model input; therefore, the first 3 years of the simulation (January 1995-December 1997) should be considered less reliable than the remaining 13 years of simulation (January 1998-December 2010). 
Groundwater-Flow Model for the Wood River Valley Aquifer System, South-Central Idaho

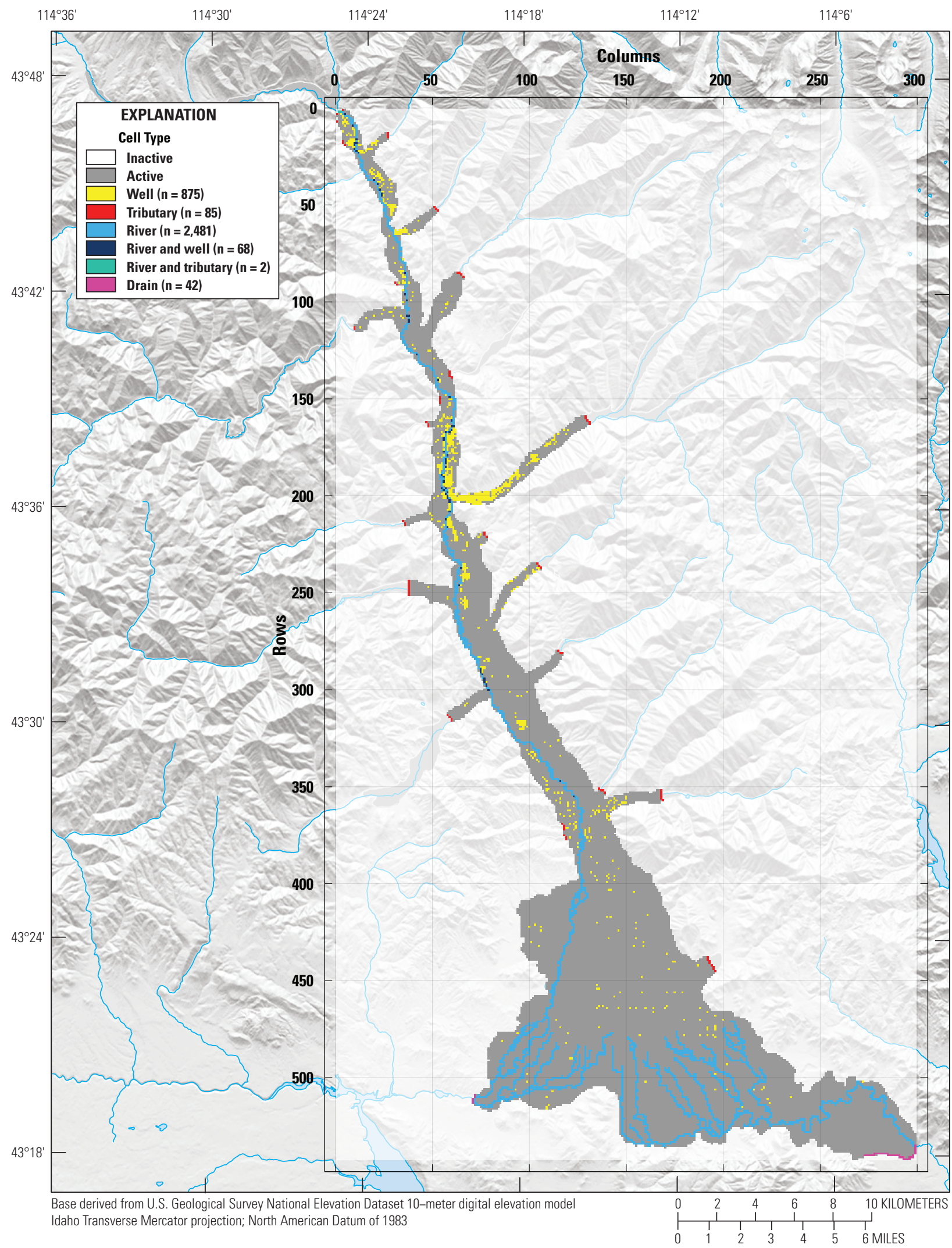

A. Model layer 1

Figure 2. Model domain and locations of boundary-condition cell types in $(A)$ model layer 1, $(B)$ model layer 2, and (C) model layer 3, Wood River Valley aquifer system, south-central Idaho. All model cells in the active domain of model layer 1 include areal recharge boundary condition. 


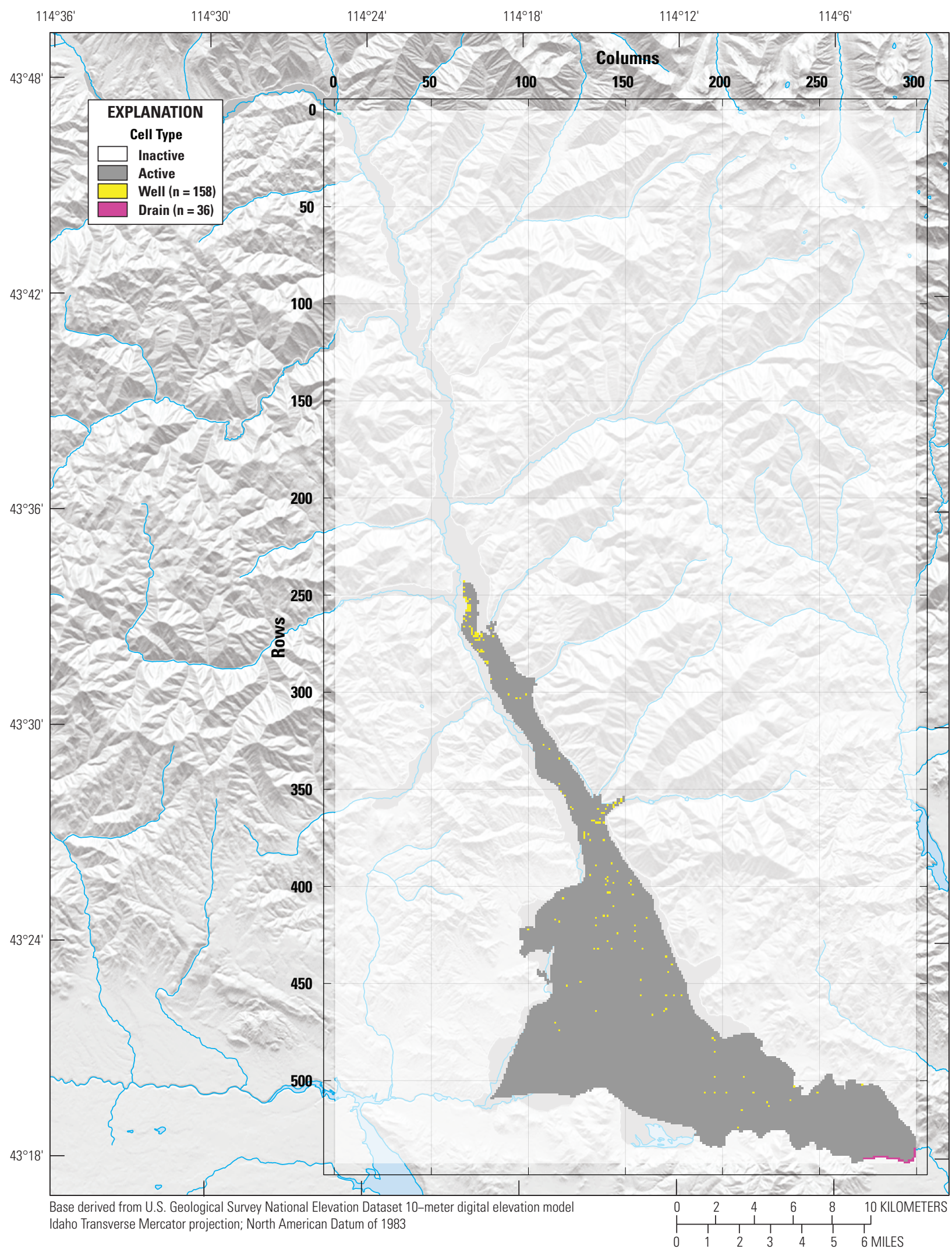

B. Model layer 2

Figure 2.-Continued 


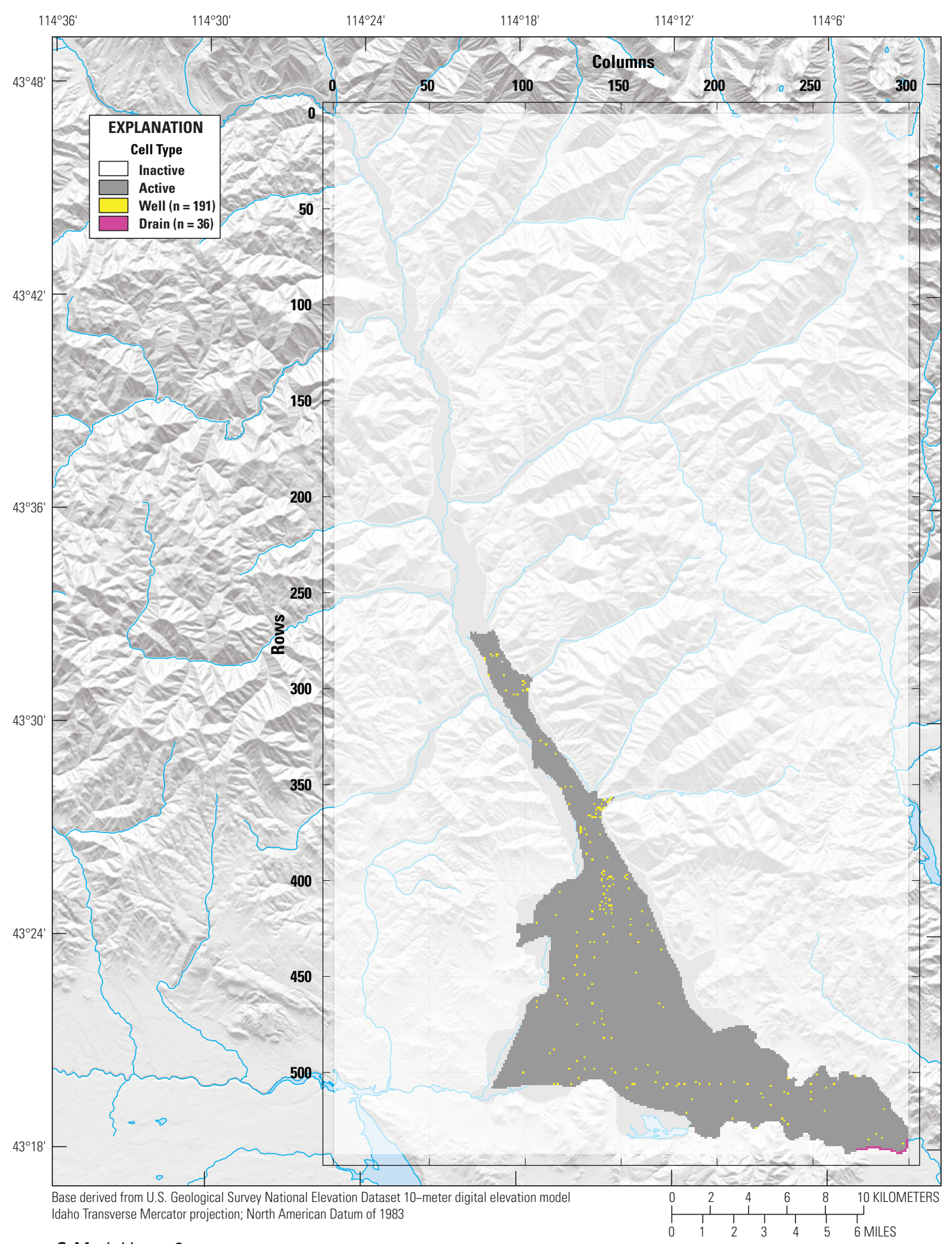

C. Model layer 3

Figure 2.-Continued 


\section{Hydraulic Properties}

The WRV aquifer system is represented as heterogeneous but transversely isotropic. Hydraulic conductivity and storage coefficient are hydraulic properties that vary spatially because of the geologic heterogeneity of the aquifer system. A pilot points parameterization method was used with PEST to estimate the distribution of these parameters in the model domain.

\section{Hydraulic Conductivity}

The hydraulic property that expresses the ease with which water can move through pore spaces and fractures of an aquifer is the hydraulic conductivity (K). Because the aquifer is modeled as transversely isotropic, as is common in horizontally bedded sedimentary deposits, $\mathrm{K}$ is specified in the horizontal and vertical principal directions. The calibrated values of horizontal hydraulic conductivity (HK) are shown for each model layer in figure 3 and in a cross section in figure 4. The descriptive statistics for calibrated HK values are shown in table 1 and specified for each hydrogeologic zone (zone). The spatial distribution of hydrogeologic zones in each model layer are defined in appendix D (fig. D8). The sediments that compose the unconfined alluvium in all model layers (zone 1) are primarily alluvial in origin and were deposited by the through-flowing Big Wood River in various depositional environments including the Bellevue fan. The texture of these sediments can range from silts and clays deposited as overbank deposits to sands and gravels deposited in stream channels. Consequently, HK could be expected to range from $7.0 \times 10^{-4} \mathrm{~m} / \mathrm{d}$ (silt, sandy silts, clayey sands, till) to $8.5 \times 10^{4} \mathrm{~m} / \mathrm{d}$ (gravel) (or $2.3 \times 10^{-3}$ to $2.8 \times 10^{5} \mathrm{ft} / \mathrm{d}$; Fetter, 2001, p. 85). The calibrated values in table 1 for zone 1 range from $9.7 \times 10^{-5} \mathrm{~m} / \mathrm{d}\left(3.2 \times 10^{-5} \mathrm{ft} / \mathrm{d}\right)$ in model layer 2 to $3.7 \times 10^{4} \mathrm{~m} / \mathrm{d}\left(1.2 \times 10^{5} \mathrm{ft} / \mathrm{d}\right)$ in model layer 1 ; most of these values are within the expected range. The few values of HK that were less than the expected range are all located in model layer 2, and may indicate an underestimation of the northern extent of the confining clay unit (zone 3). HK values in tributary canyons often are greater than adjacent values in the main valley; this may be because of a lack of measured water levels in the tributaries and uncertainty about the amount of tributary basin underflow (appendix E) represented in the model.

Values of HK in the Quaternary basalt and interbedded clay units of model layers 2 and 3 (zone 2 ) are expected to range from $8.5 \times 10^{-7} \mathrm{~m} / \mathrm{d}$ (clay) to $4.0 \times 10^{3} \mathrm{~m} / \mathrm{d}$ (permeable basalt) (or $2.8 \times 10^{-6}$ to $1.3 \times 10^{4} \mathrm{ft} / \mathrm{d}$; Spitz and Moreno, 1996 , p. 346). Calibrated values for zone 2 range from $2.5 \times 10^{-4}$ to $9.6 \times 10^{1} \mathrm{~m} / \mathrm{d}\left(8.2 \times 10^{-4}\right.$ to $\left.3.1 \times 10^{2} \mathrm{ft} / \mathrm{d}\right)($ table 1$)$ and thus are within the expected range.

The sediments that form the confining clay unit of model layer 2 (zone 3 ) were deposited in alluvial and lacustrine environments formed by volcanic damming of the Big Wood River; thus, they are somewhat finer grained than the unconfined alluvium (zone 1). The HK of zone 3 was expected to range from $8.5 \times 10^{-7} \mathrm{~m} / \mathrm{d}$ (clay) to 1.0 $\times 10^{-4} \mathrm{~m} / \mathrm{d}$ (silt, sandy silts, clayey sands, till) (or $2.8 \times 10^{-6}$ to $3.3 \times 10^{-4} \mathrm{ft} / \mathrm{d}$; Fetter, 2001, p. 85; Spitz and Moreno, 1996, p. 346). Calibrated values for zone 3 range from $3.9 \times 10^{-5}$ to $2.0 \times 10^{1} \mathrm{~m} / \mathrm{d}\left(1.2 \times 10^{-4}\right.$ to $\left.6.6 \times 10^{1} \mathrm{ft} / \mathrm{d}\right)$ (table 1$)$ with most of these values falling within the expected range. In a few cases, HK was greater than the expected range and may indicate that the confining clay unit is discontinuous and (or) leaky; it also may indicate inaccuracies in the depth to zone 4 and its thickness specified in the model.

Table 1. Descriptive statistics for the calibrated values of horizontal hydraulic conductivity and specified for each hydrogeologic zone, Wood River Valley aquifer system, south-central Idaho.

[Horizontal hydraulic conductivity: Zone 1 is hydrogeologic zone 1 consisting of the alluvium hydrogeologic unit (unit) in the unconfined aquifer; Zone 2 comprises the basalt and clay units; Zone $\mathbf{3}$ consists of the clay confining unit; Zone $\mathbf{4}$ consists of the alluvium unit in the confined aquifer. Layer is the model layer]

\begin{tabular}{|c|c|c|c|c|c|c|c|}
\hline \multirow{3}{*}{$\begin{array}{l}\text { Descriptive } \\
\text { statistic }\end{array}$} & \multicolumn{7}{|c|}{ Horizontal hydraulic conductivity, in meters per day } \\
\hline & \multicolumn{3}{|c|}{ Zone 1} & \multicolumn{2}{|c|}{ Zone 2} & \multirow{2}{*}{$\begin{array}{l}\text { Zone } 3 \\
\text { Layer } 2\end{array}$} & \multirow{2}{*}{$\begin{array}{l}\text { Zone } 4 \\
\text { Layer } 3\end{array}$} \\
\hline & Layer 1 & Layer 2 & Layer 3 & Layer 2 & Layer 3 & & \\
\hline Minimum & $7.2 \times 10^{-1}$ & $9.7 \times 10^{-5}$ & $2.3 \times 10^{1}$ & $2.5 \times 10^{-4}$ & 5.5 & $3.9 \times 10^{-5}$ & $2.4 \times 10^{1}$ \\
\hline 1st quartile & $2.9 \times 10^{1}$ & $1.2 \times 10^{1}$ & $3.6 \times 10^{2}$ & 7.5 & $1.0 \times 10^{1}$ & $6.0 \times 10^{-5}$ & $9.9 \times 10^{2}$ \\
\hline Median & $1.2 \times 10^{2}$ & $1.8 \times 10^{1}$ & $5.5 \times 10^{2}$ & 9.1 & $1.4 \times 10^{1}$ & $1.2 \times 10^{-4}$ & $1.5 \times 10^{3}$ \\
\hline Mean & $3.1 \times 10^{2}$ & $2.5 \times 10^{1}$ & $7.8 \times 10^{2}$ & 9.0 & $2.0 \times 10^{1}$ & 1.3 & $1.5 \times 10^{3}$ \\
\hline 3rd quartile & $2.9 \times 10^{2}$ & $2.8 \times 10^{1}$ & $9.1 \times 10^{2}$ & $1.1 \times 10^{1}$ & $2.2 \times 10^{1}$ & $2.9 \times 10^{-4}$ & $1.9 \times 10^{3}$ \\
\hline Maximum & $3.7 \times 10^{4}$ & $2.4 \times 10^{2}$ & $5.2 \times 10^{3}$ & $1.4 \times 10^{1}$ & $9.6 \times 10^{1}$ & $2.0 \times 10^{1}$ & $2.8 \times 10^{3}$ \\
\hline
\end{tabular}




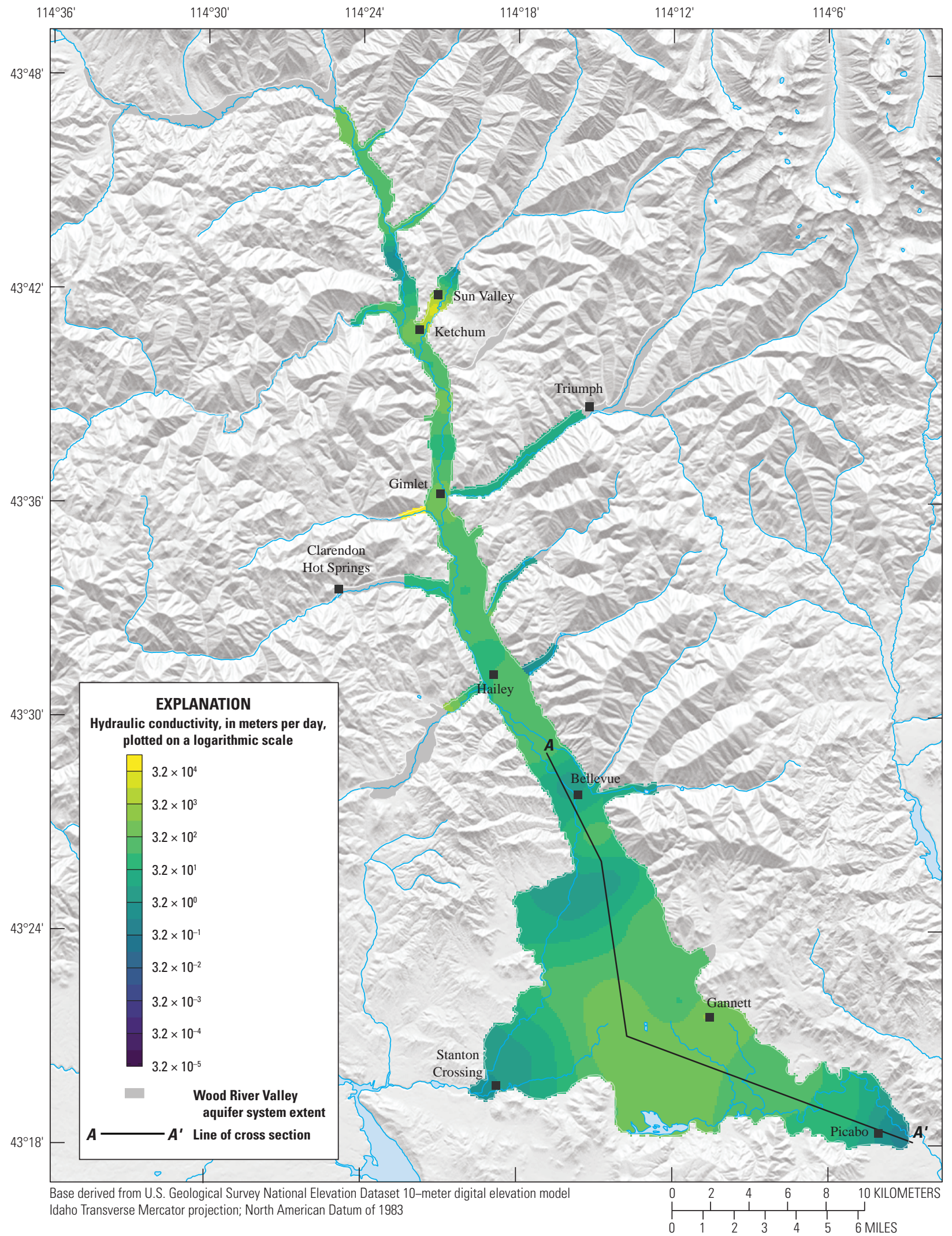

A. Model layer 1

Figure 3. Spatial distribution of the calibrated horizontal hydraulic conductivity in $(A)$ model layer $1,(B)$ model layer 2, and $(C)$ model layer 3, Wood River Valley aquifer system, south-central Idaho. 


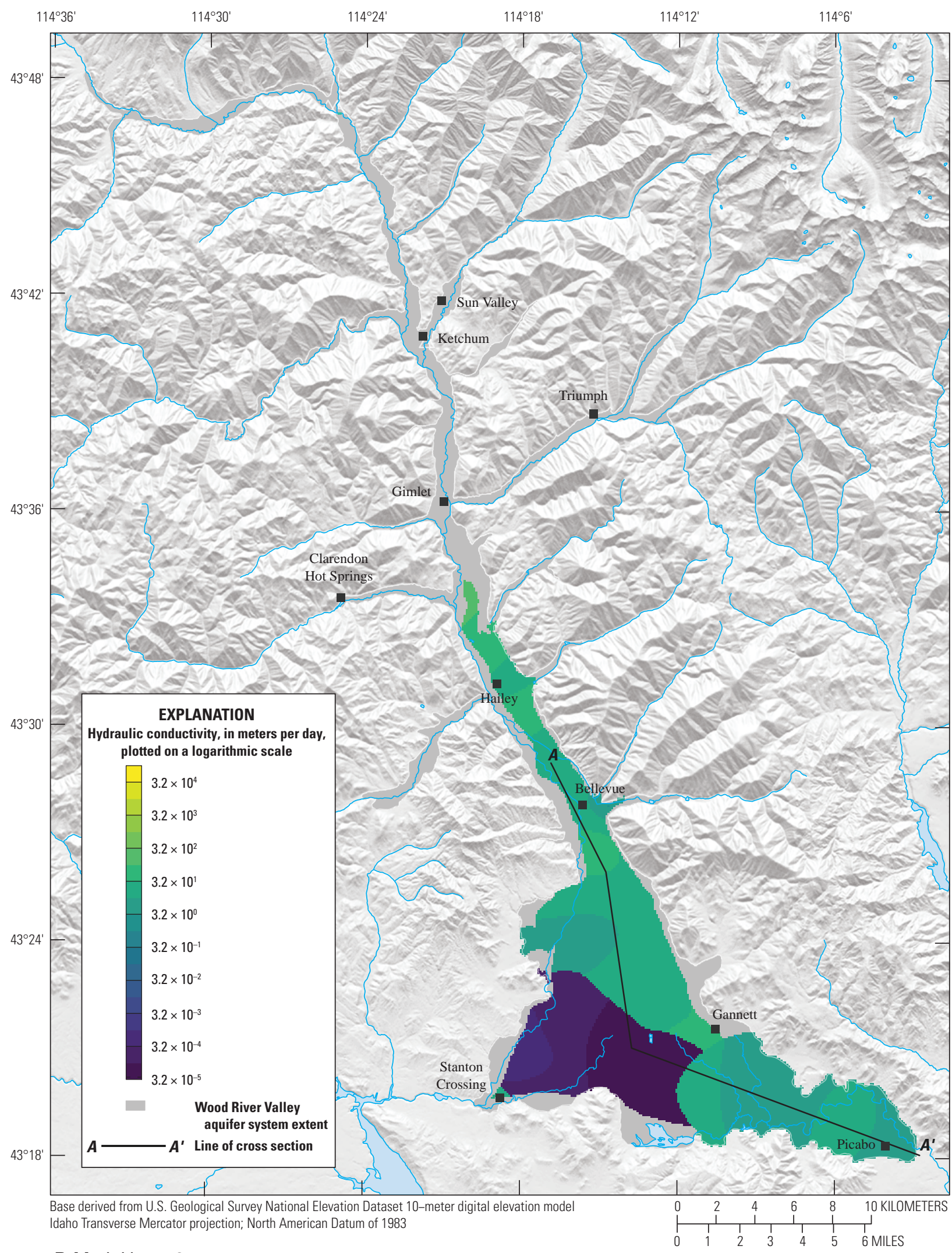

B. Model layer 2

Figure 3.-Continued 


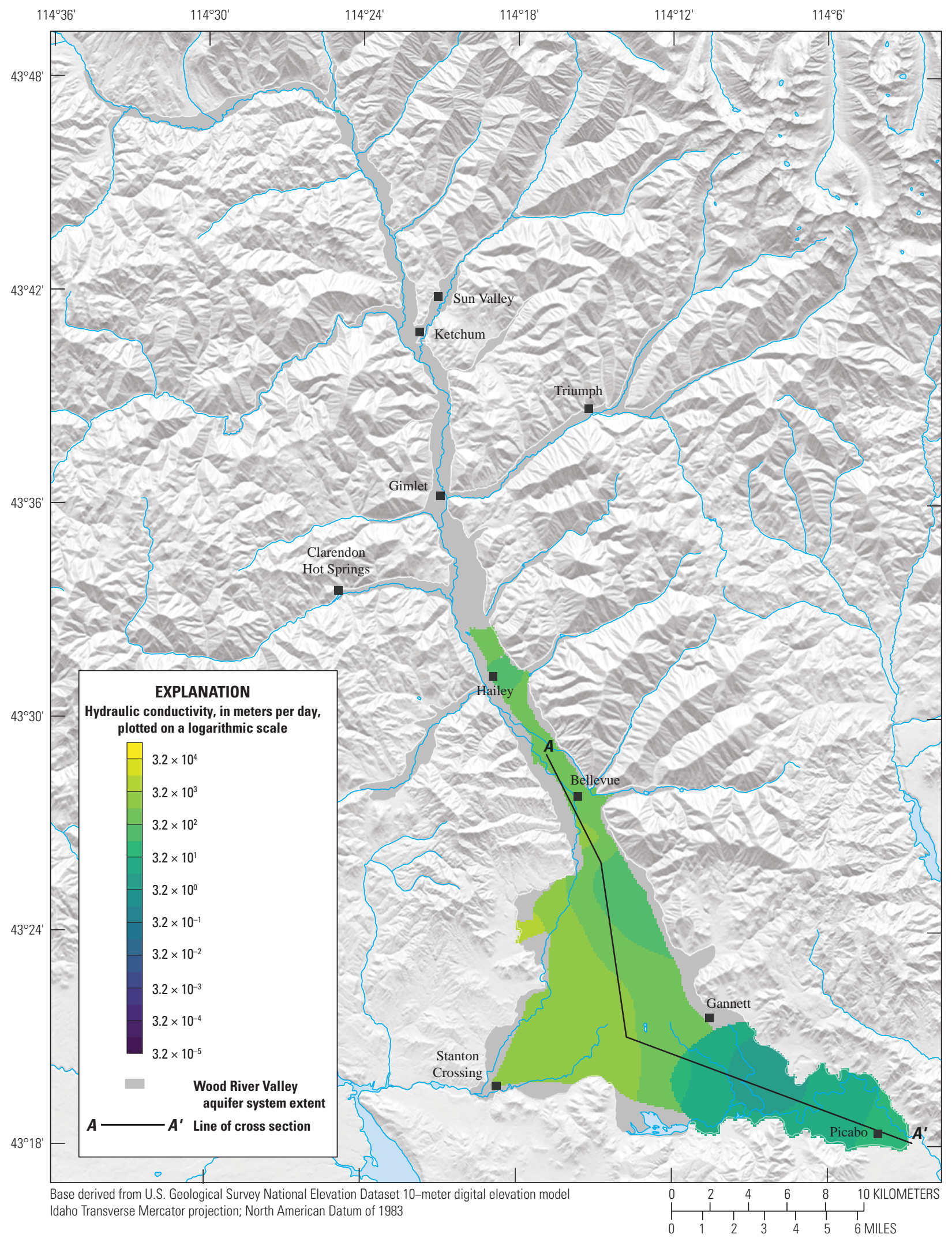

C. Model layer 3

Figure 3.-Continued 


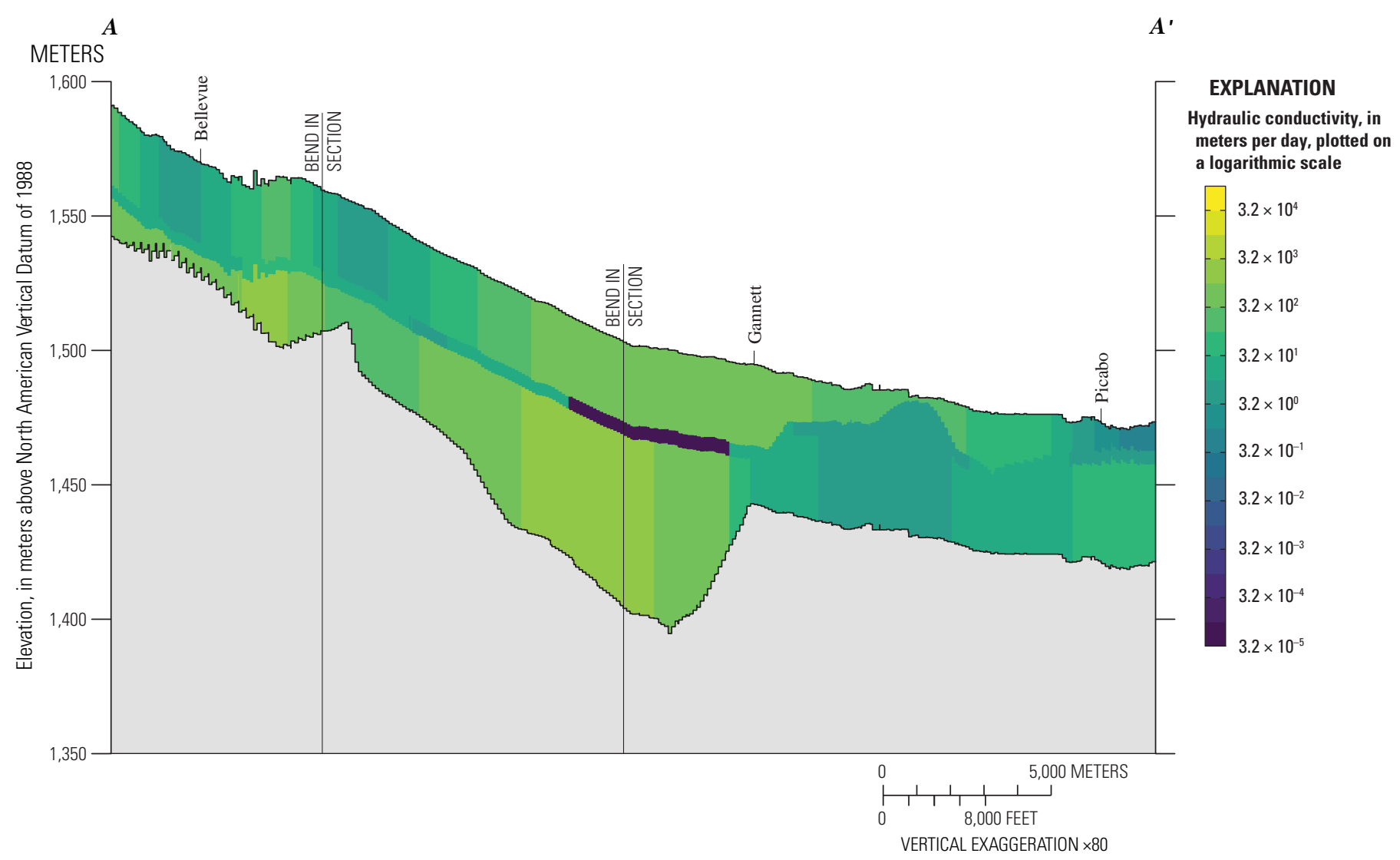

Figure 4. Calibrated horizontal hydraulic conductivity along the line of cross section $A-A^{\prime}$, Wood River Valley aquifer system, south-central Idaho. Line of cross section shown in figure 3.

The confined alluvium of model layer 3 (zone 4), located directly beneath the confining clay unit (zone 3 ), was expected to have HK values that were slightly smaller than values in the unconfined alluvium (zone 1); this assumes greater consolidation of sediments in the confined aquifer. Calibrated values for zone 4 range from $2.4 \times 10^{1}$ to $2.8 \times 10^{3} \mathrm{~m} / \mathrm{d}\left(7.9 \times 10^{1}\right.$ to $\left.9.2 \times 10^{3} \mathrm{ft} / \mathrm{d}\right)($ table 1$)$ and are within the expected range for alluvium $\left(7.0 \times 10^{-4}\right.$ to $\left.8.5 \times 10^{4} \mathrm{~m} / \mathrm{d}\right)($ Spitz and Moreno, 1996, p. 346-349). Values were relatively large with respect to the calibrated HK values for the unconfined alluvium. The median HK values for zones 1 and 4 were $2.3 \times 10^{2} \mathrm{~m} / \mathrm{d}\left(7.5 \times 10^{2} \mathrm{ft} / \mathrm{d}\right)$ and $1.5 \times 10^{3} \mathrm{~m} / \mathrm{d}$ $\left(4.9 \times 10^{3} \mathrm{ft} / \mathrm{d}\right)$, respectively. The large values of HK in zone 4 may represent coarser sediment deposited as outwash during a wet glacial period.

Vertical anisotropy is the ratio of horizontal to vertical hydraulic conductivity. Todd (1980, p. 81) indicates that vertical anisotropy values "usually fall in the range of 2 to 10 for alluvium, but values up to 100 or more occur where clay layers are present.” Moench and others (2001) report a value of 202 for glacial outwash. A single value of vertical anisotropy is specified for all hydrogeologic zones. The calibrated vertical anisotropy is 138 ; that is, the vertical hydraulic conductivity is 138 times smaller than HK.

\section{Storage Coefficient}

The hydraulic property that expresses the capacity of the aquifer to take water into or release water from storage is the confined storage coefficient (SC). SC is a dimensionless quantity that is defined as the volume of water released from or taken into storage per unit change in hydraulic head in the aquifer, per unit area of the aquifer. The calibrated values of SC are shown for each model layer in figure 5 , and in a vertical cross section in figure 6 . The descriptive statistics for calibrated SC values are shown in table 2. 


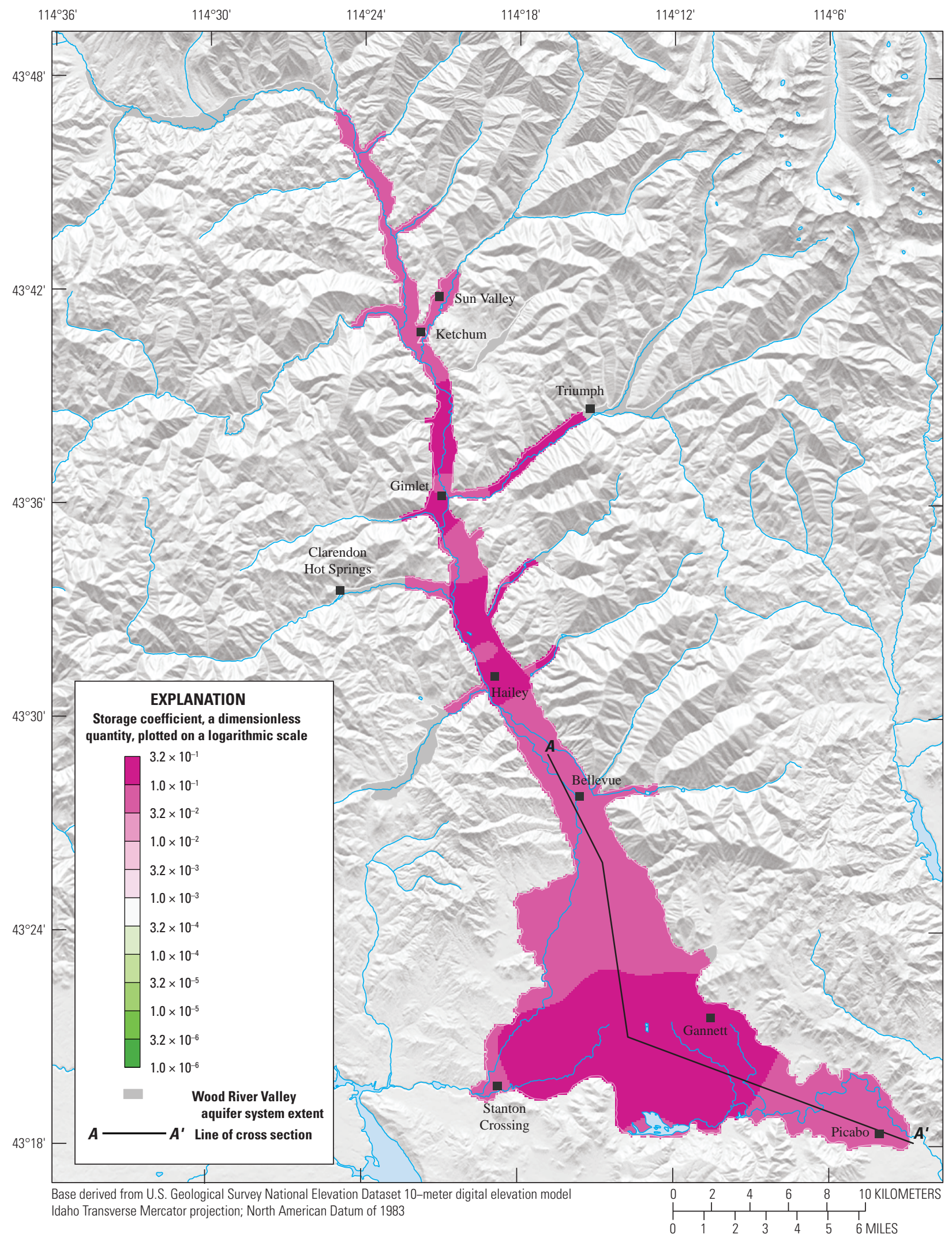

A. Model layer 1

Figure 5. Spatial distribution of the calibrated storage coefficient in $(A)$ model layer $1,(B)$ model layer 2 , and $(C)$ model layer 3, Wood River Valley aquifer system, south-central Idaho. 


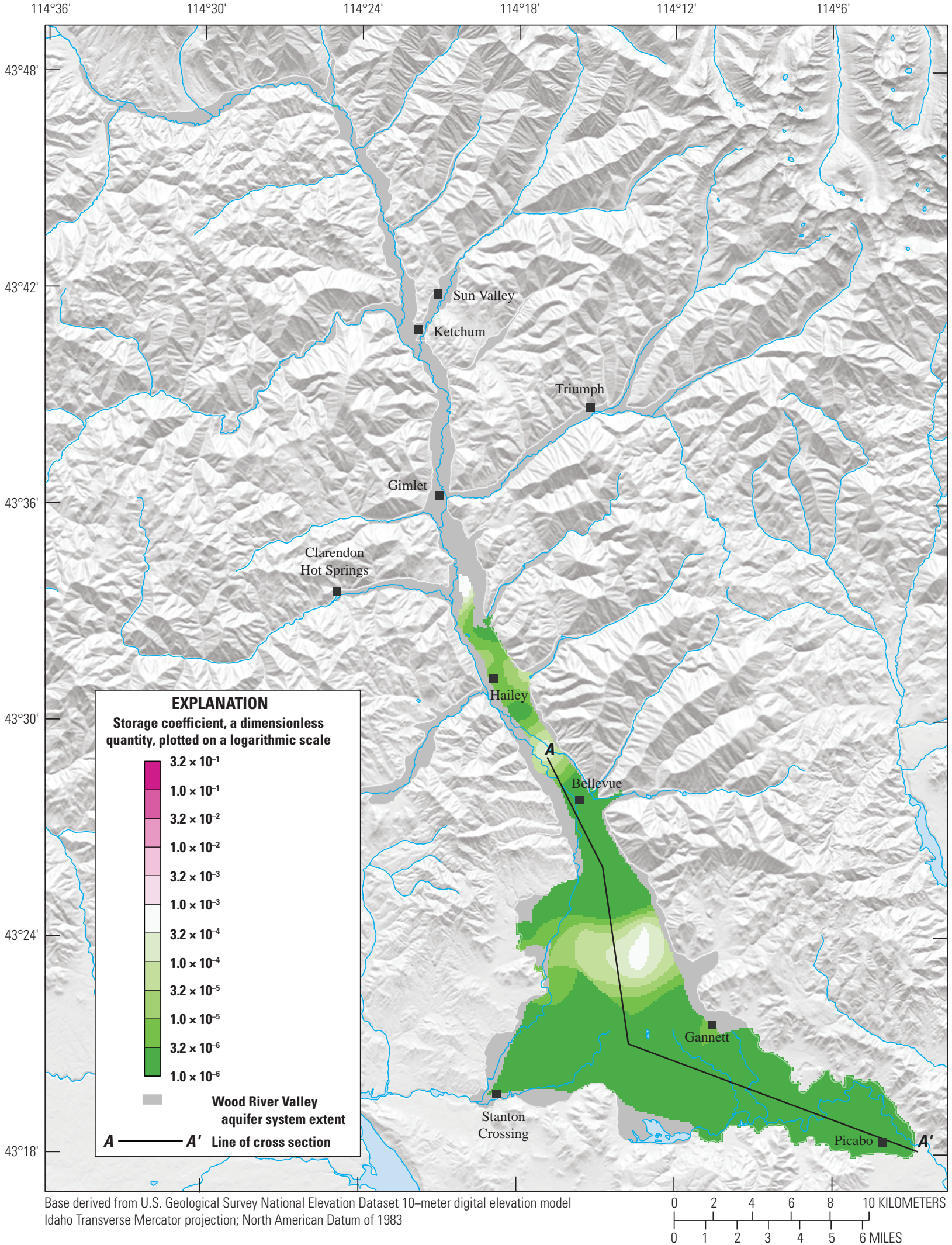

B. Model layer 2

Figure 5.-Continued 


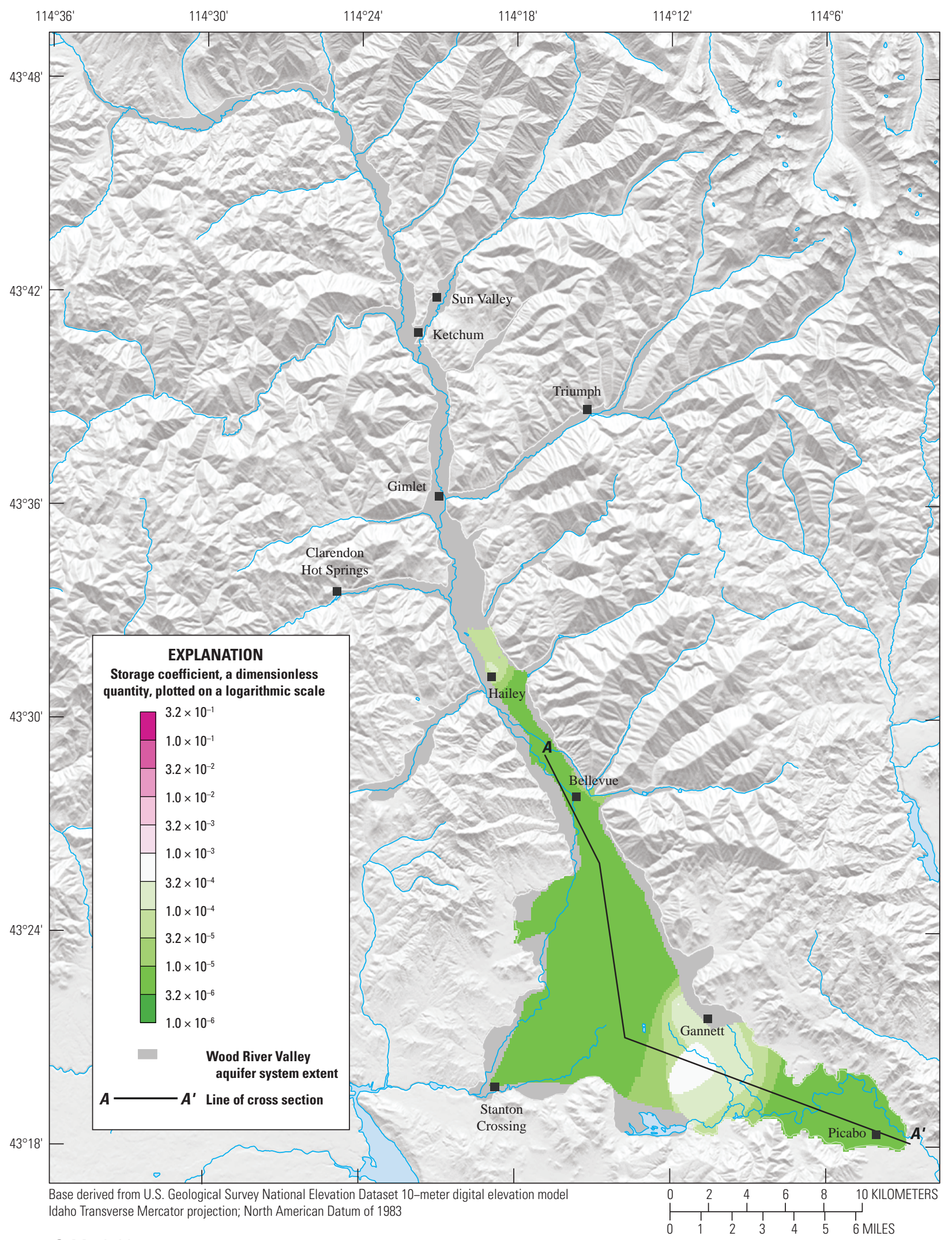

C. Model layer 3

Figure 5.-Continued 


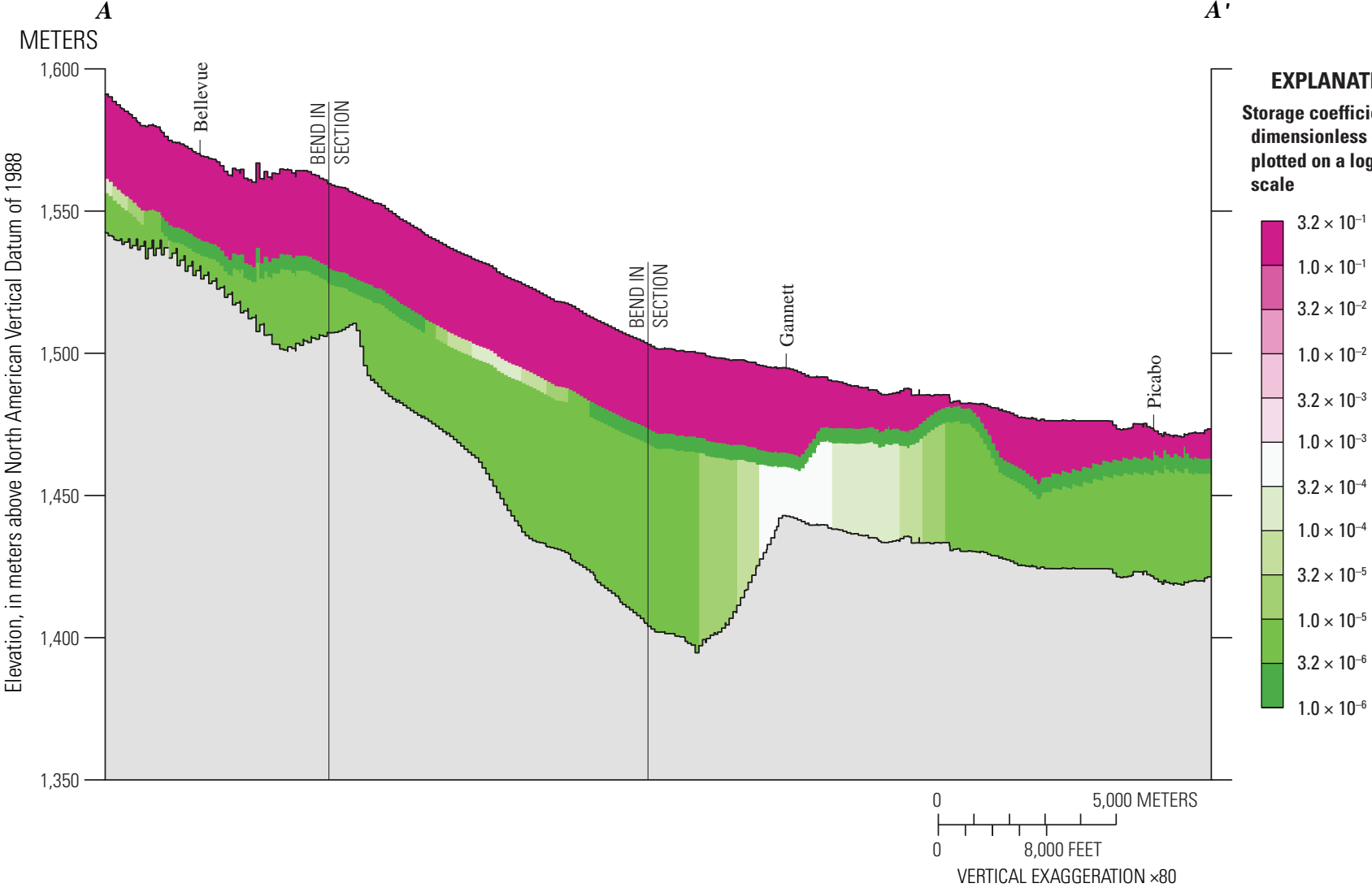

Figure 6. Calibrated values of storage coefficient along transect line $A-A^{\prime}$ shown in figure 5 , Wood River Valley, south-central Idaho.

Table 2. Descriptive statistics for the calibrated storage coefficient and specified for each hydrogeologic zone, Wood River Valley aquifer system, south-central Idaho.

[Storage coefficient: Zone1 is hydrogeologic zone 1 consisting of the alluvium hydrogeologic unit (unit) in the unconfined aquifer; Zone2 comprises the basalt and clay units; Zone $\mathbf{3}$ consists of the clay confining unit; Zone $\mathbf{4}$ consists of the alluvium unit in the confined aquifer. Layer is the model layer]

\begin{tabular}{|c|c|c|c|c|c|c|c|}
\hline \multirow{3}{*}{$\begin{array}{c}\text { Descriptive } \\
\text { statistic }\end{array}$} & \multicolumn{7}{|c|}{ Storage coefficient, a dimensionless quantity } \\
\hline & \multicolumn{3}{|c|}{ Zone 1} & \multicolumn{2}{|c|}{ Zone 2} & \multirow{2}{*}{$\begin{array}{c}\text { Zone } 3 \\
\text { Layer } 2\end{array}$} & \multirow{2}{*}{$\begin{array}{c}\text { Zone } 4 \\
\text { Layer } 3\end{array}$} \\
\hline & Layer 1 & Layer 2 & Layer 3 & Layer 2 & Layer 3 & & \\
\hline Minimum & $1.0 \times 10^{-1}$ & $1.0 \times 10^{-6}$ & $5.0 \times 10^{-6}$ & $1.0 \times 10^{-6}$ & $5.0 \times 10^{-6}$ & $1.0 \times 10^{-6}$ & $5.0 \times 10^{-6}$ \\
\hline 1st quartile & $1.0 \times 10^{-1}$ & $1.0 \times 10^{-6}$ & $5.0 \times 10^{-6}$ & $1.0 \times 10^{-6}$ & $5.0 \times 10^{-6}$ & $1.0 \times 10^{-6}$ & $5.0 \times 10^{-6}$ \\
\hline Median & $1.0 \times 10^{-1}$ & $4.9 \times 10^{-6}$ & $5.0 \times 10^{-6}$ & $1.0 \times 10^{-6}$ & $6.9 \times 10^{-6}$ & $1.0 \times 10^{-6}$ & $5.0 \times 10^{-6}$ \\
\hline Mean & $1.5 \times 10^{-1}$ & $4.0 \times 10^{-5}$ & $1.8 \times 10^{-5}$ & $1.1 \times 10^{-6}$ & $8.1 \times 10^{-5}$ & $1.3 \times 10^{-6}$ & $3.0 \times 10^{-5}$ \\
\hline 3rd quartile & $1.9 \times 10^{-1}$ & $3.2 \times 10^{-5}$ & $5.0 \times 10^{-6}$ & $1.0 \times 10^{-6}$ & $1.3 \times 10^{-4}$ & $1.0 \times 10^{-6}$ & $8.0 \times 10^{-6}$ \\
\hline Maximum & $3.0 \times 10^{-1}$ & $9.9 \times 10^{-4}$ & $3.2 \times 10^{-4}$ & $6.1 \times 10^{-6}$ & $4.9 \times 10^{-4}$ & $7.6 \times 10^{-6}$ & $5.7 \times 10^{-4}$ \\
\hline
\end{tabular}


Because all model layers were simulated using saturated conditions (see section, "Specified-Thickness Approximation," in appendix D for details), the SC in the partially saturated (water-table) conditions of model layer 1 (or zone 1) is virtually equal to the specific yield. Specific yield is a dimensionless quantity defined as the volume of water expressed as a volumetric fraction of the saturated bulk aquifer volume that a given aquifer will yield when all the water is allowed to drain out of it under the forces of gravity. Specific yield values in the literature for unconsolidated deposits range from 0.0 for clay to 0.35 for fine gravel (Johnson, 1967). The calibrated SC values in model layer 1 ranged from 0.10 to 0.30 for alluvium (zone 1) - all of which are within the expected range of specific yield values.

For the saturated conditions of model layers 2 and 3 (zones 2-4), the typical SC values ranged from $5.0 \times 10^{-5}$ to $5.0 \times 10^{-3}$ (Freeze and Cherry, 1979, p. 60). The calibrated $\mathrm{SC}$ values for saturated conditions ranged from $1.0 \times 10^{-6}$ to $7.6 \times 10^{-6}$ for clay (zone 3 ), and $5.0 \times 10^{-6}$ to $5.7 \times 10^{-4}$ for alluvium (zone 4). SC values for confining units less than $1.0 \times 10^{-5}$ are more typical of consolidated rock than unconsolidated sediment (Domenico and Mifflin, 1965), although they are not unrealistic for sediment.

\section{Hydrologic Boundaries}

Hydrologic boundaries in the groundwater-flow model define the locations and conditions of flow into and out of the active model domain. For this report, the volumetric flow rate at a boundary is given in terms of groundwater recharge or discharge; that is, positive flow rates indicate inflow (water that recharges or flows into the aquifer) and negative flow rates indicate outflow (water that discharges or flows out of the aquifer). Specified flows into the active model grid occur in the "tributary cells" and represent groundwater that originates as precipitation in the major tributary basins (fig. 2). Specified flows also occur in the active cells of model layer 1 and represent groundwater flow (inflows minus outflows) across the water table. Within the model grid, specified outflows occur at 'well' cell types and represent pumping in waterproduction wells (fig. 2). Head-dependent conditions occur in 'drain' cell types and represent groundwater discharge across the Stanton Crossing and Silver Creek outlet boundaries. Head-dependent conditions also occur in 'river' cell types and represent the stream-aquifer flow exchange (that is, streamflow gains and losses) (fig. 2).

\section{Tributary Basin Underflow}

Tributary basin underflow (underflow) is defined as groundwater flow into the model domain that originates as precipitation in the tributary basins. Underflow enters the active model grid through 'tributary' cell types located in the major tributary canyons and beneath the valley floor at the confluence of the Big Wood River and the North Fork
Big Wood River (BWR Upper) (table 3, figs. 7 and 8). BWR Upper is classified as a major tributary canyon in this report. Twenty-three major tributary canyons were identified in the WRV (table 3). Flows were specified at tributary cells placed in the upper part of the tributary canyons to help constrain model errors that may propagate into the model from these model boundaries. Because of the scarcity of field observations in the tributary canyons, there is large uncertainty as to the historical flow contribution from each of the tributary basins. Therefore, simulated hydraulic heads in the tributary canyons should be considered less reliable than in the main valley floor.

For each of the major tributary canyons, the specified underflow was calculated by multiplying the long-term mean volumetric flow rate of a tributary by the seasonal scaling index (appendix E). The seasonal scaling index (SI) is identical for all tributaries, and is based on an amplitude reduced moving average of streamflow recorded at the Big Wood River at Hailey streamgage (13139510, fig. 1). The streamflow hydrograph is smoothed using a moving average duration and amplitude-reduction factor. Specifying a longer moving average duration or larger reduction factor results in an increased level of smoothing. The calibrated moving average duration and reduction factor were 248.6 days (about 8.2 months) and 10.0, respectively. The moving average duration was only slightly smaller than its 275 day (9 month) starting value during the model calibration process; therefore, the expected timing of recharge events (such as spring snowmelt) is preserved in the tributary basin underflow hydrographs. The calibrated amplitude-reduction factor coincides with the upper bound of the parameter during model calibration at 10.0 .

Calibrated long-term mean tributary basin underflows are shown in table 3 and shown spatially and proportionally in figure 7 . Volumetric flow rates that coincide with the lower bound of the parameter during calibration, at one-hundredth of its empirically derived estimate, occurred at Adams Gulch (tributary No. 1), Chocolate Gulch (tributary No. 3), Elkhorn Gulch (tributary No. 11), Greenhorn Gulch (tributary No. 12), Ohio Gulch (tributary No. 16), and Slaughterhouse Gulch (tributary No. 20). With the exception of Greenhorn Gulch (tributary No. 12), the modeled boundary cells for these tributaries are adjacent (or near adjacent) to the valley floor. Tributaries with long-term mean volumetric flow rates greater than 2,000 m³ (600 acre-ft/yr) occurred where boundary cells were located several hundreds of meters from the main valley floor - the exceptions being BWR Upper (tributary No. 2) and Oregon Gulch (tributary No. 17), which are located in the most northern part of the model area. This may indicate that a buffer, measured as the distance between the specified flow cells (or tributary cells) and the main valley floor, is needed to accurately simulate the flow contributions from major tributary basins. This buffer may help to reconcile the seasonal differences in groundwater flow between the main valley floor and the tributary canyons. 
Calibrated Groundwater Flow Model

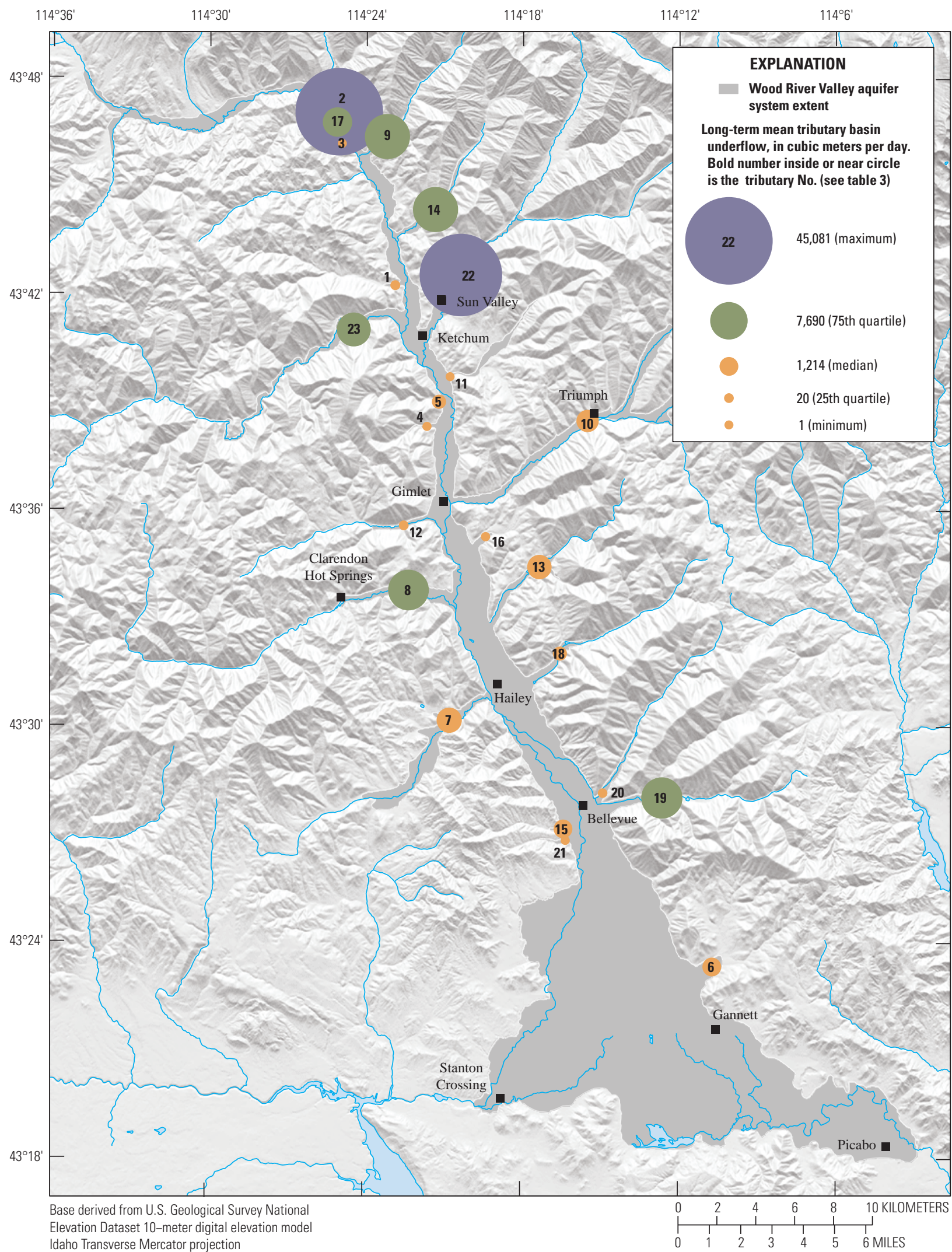

Figure 7. Spatial distribution of long-term mean tributary basin underflow in the Wood River Valley aquifer system, south-central Idaho. 


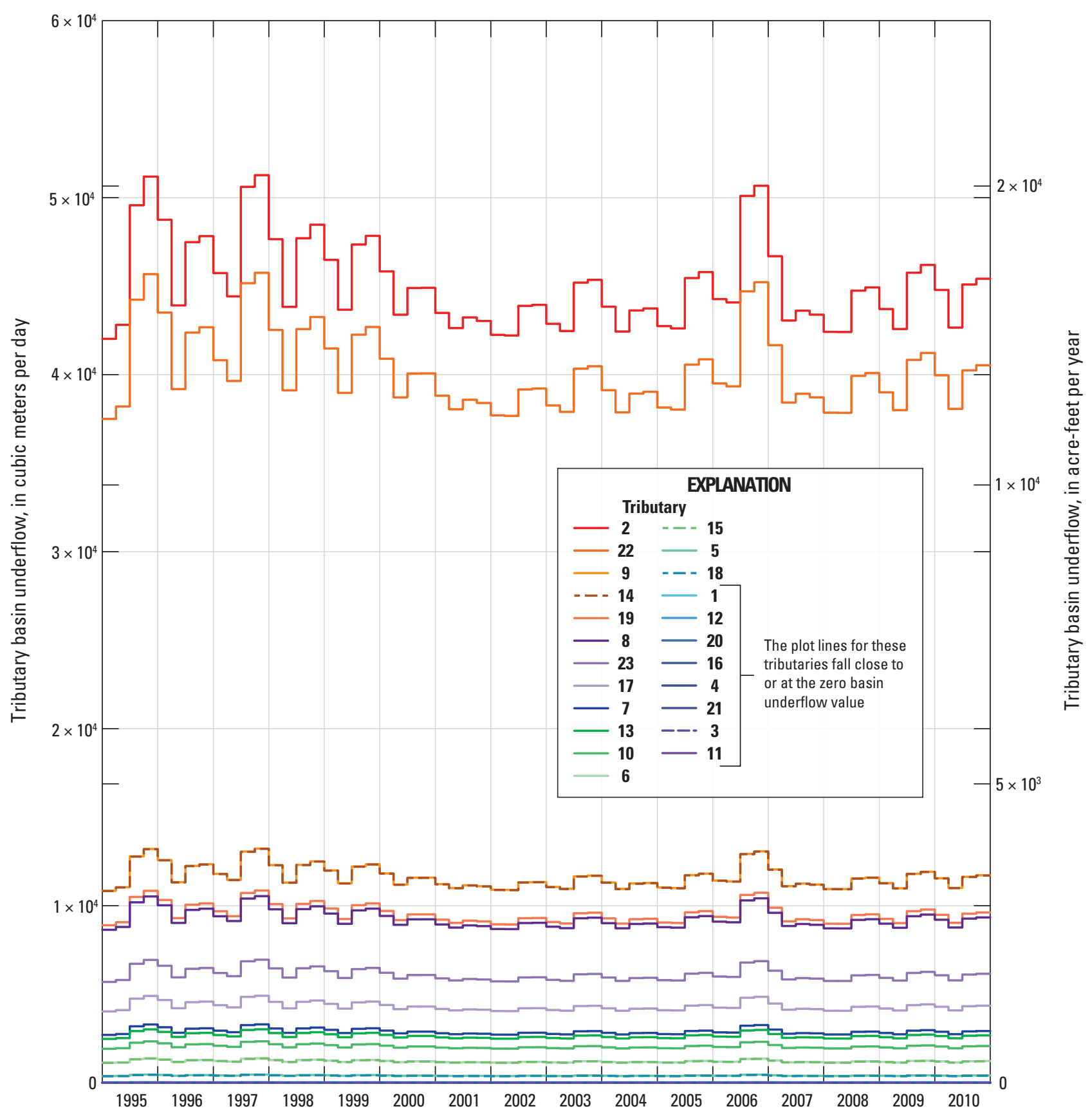

Figure 8. Tributary basin underflow in the Wood River Valley aquifer system, south-central Idaho. 
Table 3. Long-term mean tributary basin underflow in the Wood River Valley aquifer system, south-central Idaho.

[Tributary No.: An identifier used to locate the tributary boundaries in figure 7. Starting: Starting value used in calibration for the long-term mean tributary basin underflow (underflow) during the period of transient model simulation (1995-2010). Upper and Lower bounds Specified range for long-term mean underflow during the model-calibration process. Calibrated: Calibrated value of long-term mean underflow. Abbreviations: $\mathrm{m}^{3} / \mathrm{d}$, cubic meter per day; acre- $\mathrm{ft} / \mathrm{yr}$, acre-foot per year]

\begin{tabular}{|c|c|c|c|c|c|c|}
\hline Tributary canyon & $\begin{array}{c}\text { Tributary } \\
\text { No. }\end{array}$ & $\begin{array}{c}\text { Starting } \\
\left(\mathrm{m}^{3} / \mathrm{d}\right)\end{array}$ & $\begin{array}{l}\text { Lower } \\
\text { bound } \\
\left(\mathrm{m}^{3} / \mathrm{d}\right)\end{array}$ & $\begin{array}{l}\text { Upper } \\
\text { bound } \\
\left(\mathrm{m}^{3} / \mathrm{d}\right)\end{array}$ & $\begin{array}{c}\text { Calibrated } \\
\qquad\left(\mathrm{m}^{3} / \mathrm{d}\right)\end{array}$ & $\begin{array}{l}\text { Calibrated } \\
\text { (acre-ft/yr) }\end{array}$ \\
\hline Adams Gulch & 1 & 2,874 & 29 & 11,888 & 29 & 9 \\
\hline BWR Upper & 2 & 2,063 & 21 & 211,600 & 45,082 & 13,349 \\
\hline Chocolate Gulch & 3 & 197 & 2 & 793 & 2 & 1 \\
\hline Clear Creek & 4 & 358 & 4 & 1,441 & 4 & 1 \\
\hline Cold Springs Gulch & 5 & 591 & 6 & 2,378 & 409 & 121 \\
\hline Cove Canyon & 6 & 482 & 5 & 7,565 & 1,215 & 360 \\
\hline Croy Creek & 7 & 2,379 & 24 & 16,138 & 2,900 & 859 \\
\hline Deer Creek & 8 & 4,925 & 49 & 49,532 & 9,269 & 2,745 \\
\hline Eagle Creek & 9 & 3,423 & 34 & 11,491 & 11,632 & 3,444 \\
\hline East Fork & 10 & 1,586 & 16 & 80,548 & 2,058 & 610 \\
\hline Elkhorn Gulch & 11 & 173 & 2 & 8,429 & 2 & 1 \\
\hline Greenhorn Gulch & 12 & 2,300 & 23 & 20,425 & 23 & 7 \\
\hline Indian Creek & 13 & 8,107 & 81 & 6,736 & 2,656 & 786 \\
\hline Lake Creek & 14 & 8,092 & 81 & 11,671 & 11,619 & 3,440 \\
\hline Lees Gulch & 15 & 403 & 4 & 1,621 & 1,204 & 356 \\
\hline Ohio Gulch & 16 & 716 & 7 & 2,882 & 7 & 2 \\
\hline Oregon Gulch & 17 & 1,163 & 12 & 4,683 & 4,322 & 1,280 \\
\hline Quigley Creek & 18 & 1,896 & 19 & 10,411 & 395 & 117 \\
\hline Seamans Gulch & 19 & 6,557 & 66 & 12,428 & 9,549 & 2,828 \\
\hline Slaughterhouse Gulch & 20 & 1,700 & 17 & 7,961 & 17 & 5 \\
\hline Townshead Gulch & 21 & 134 & 1 & 540 & 3 & 1 \\
\hline Trail Creek & 22 & 9,739 & 97 & 76,081 & 40,231 & 11,913 \\
\hline Warm Springs Creek & 23 & 1,631 & 16 & 121,038 & 6,112 & 1,810 \\
\hline
\end{tabular}

Because of the close proximity of some of the tributary boundary cells to the main valley floor, the flow contributions from individual tributary canyons are considered highly uncertain; nevertheless, the total simulated underflow contributed from all major tributary basins in the WRV $\left(1.5 \times 10^{5} \mathrm{~m}^{3} / \mathrm{d}\left[4.4 \times 10^{4} \mathrm{acre}-\mathrm{ft} / \mathrm{yr}\right]\right)$ is reasonable.

\section{Groundwater Diversions}

Groundwater is diverted from the WRV aquifer system by means of either pumping wells or flowing artesian wells. These groundwater diversions are used for irrigation and municipal purposes. Withdrawals from a total of 1,243 production wells were simulated in the model. Groundwater discharge from a well was represented in the model as a specified outflow (or negative volumetric flow rate) from active model cells coinciding with a well open interval ('well' cell types are shown in fig. 2). For open intervals that extend beyond a single model layer, the flow contribution from each model layer was assumed to be proportional to the transmissivity of each layer. Simulated discharge rates were estimated using groundwater-diversion records, where available. During the transient-model simulation period (1995-2010), most groundwater diversions were not measured or recorded. Recorded groundwater diversions generally were limited to municipal diversions and groundwater diversions regulated by Water District 37 or 37M during the model-simulation period. Unrecorded groundwater diversions were estimated based on irrigation demand, recorded surface-water diversions, canal seepage, and irrigation efficiency, the details of which are described in appendix G. The estimated groundwater diversions comprised about 80 percent of the total simulated groundwater diversions by volume.

The total groundwater discharge rate (specified as a negative volumetric flow rate) from production wells in the model domain is shown in figure 9. Groundwater discharge rates ranged from $1.1 \times 10^{4}$ to $9.4 \times 10^{5} \mathrm{~m}^{3} / \mathrm{d}$ (or 3,300 to $2.7 \times 10^{5} \mathrm{acre}-\mathrm{ft} / \mathrm{yr}$ ) during the model-simulation period, with a mean of $2.1 \times 10^{5} \mathrm{~m}^{3} / \mathrm{d}\left(6.2 \times 10^{4}\right.$ acre-ft/yr). Flow rate values were largest during the irrigation season (April-October). 


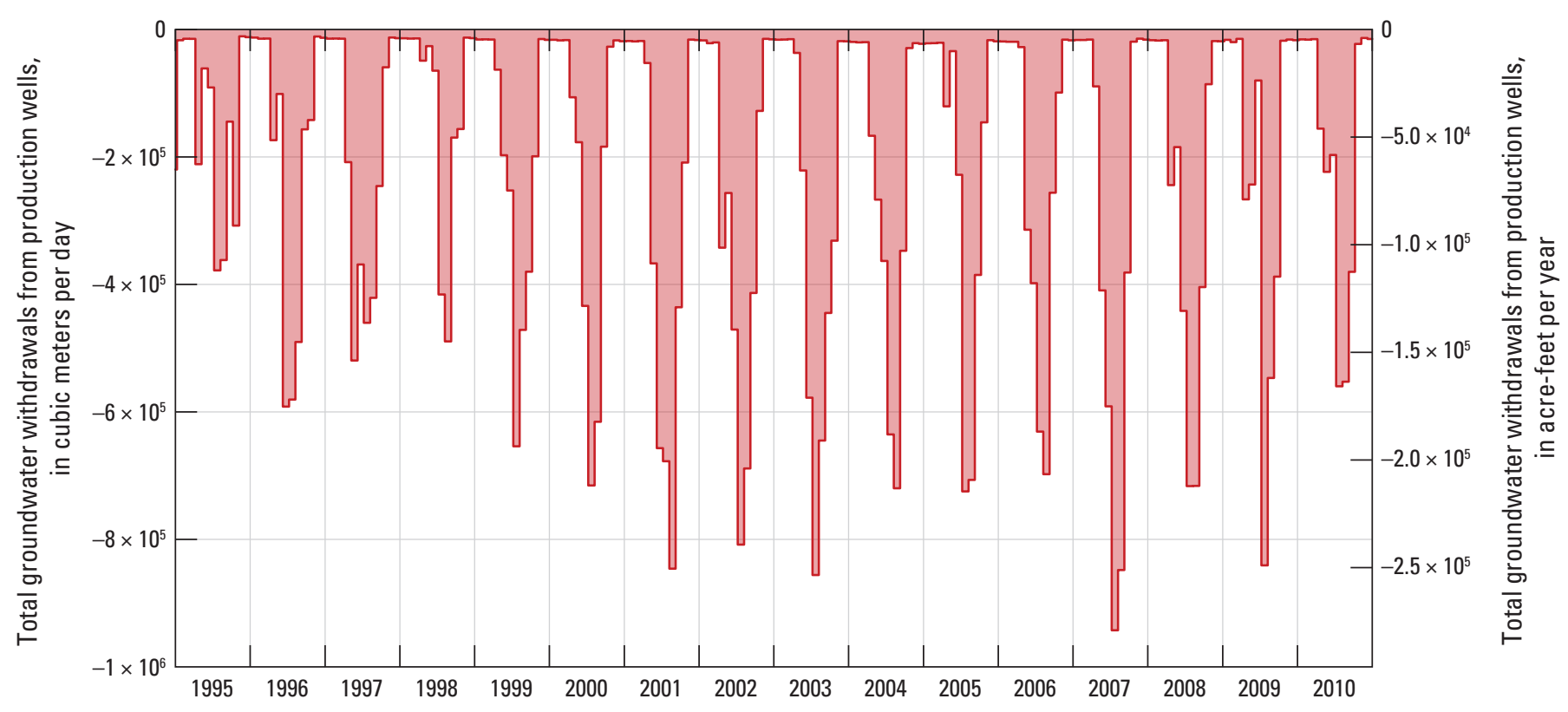

Figure 9. Total groundwater withdrawals from production wells in the groundwater-flow model domain, Wood River Valley aquifer system, south-central Idaho.

\section{Areal Recharge of Precipitation and Applied Irrigation}

In this report, areal recharge encompass both groundwater recharge from precipitation and applied irrigation, and is expressed as a volumetric flow rate. A positive flow rate represents water that infiltrates the soil, passes beyond the root zone, and recharges the aquifer; a negative flow rate represents aquifer water that is drawn upward into the unsaturated zone by capillary forces and is discharged out of the aquifer. Areal recharge on nonirrigated lands (also known as natural recharge) is expressed as precipitation minus evapotranspiration, with a maximum limit placed on the recharge rate that is based on the vertical permeability of soils in the study area (appendix F). Beneath irrigated lands and unlined canals, areal recharge (or incidental recharge) was estimated using a water-balance model, the details of which are described in appendix G. Components of this water-balance model include surface-water diversions, surface-water return flow, canal seepage, groundwater diversions (including pumping well and flowing-artesian well diversions), municipal wastewater-treatment-plant discharge, and crop-irrigation requirements. The irrigation efficiency, defined here as the ratio between irrigation water actually used by growing plants and the total water delivered from canals and wells to supply such irrigation water, was the only parameter in the water-balance model that was varied during the model-calibration process. Irrigation efficiency was only used to calculate estimated groundwater diversions when recorded surface water and groundwater diversions were inadequate to meet irrigation demand. The model irrigation efficiency value does not represent irrigation efficiency during stress periods when recorded diversions are adequate to meet the crop irrigation requirement (CIR).

A starting irrigation efficiency of 0.75 (or 75 percent) was applied for all irrigation entities in the model domain with unmeasured groundwater diversions (table 4). This starting value also was used as a preferred condition during the model-calibration process (appendix H). The lower and upper bounds placed on irrigation efficiencies during model calibration was 0.50 and 0.90 , respectively. Table 4 indicates the calibrated irrigation efficiencies for each irrigation entity in the model domain. The spatial distribution of irrigation efficiencies within the model domain is shown in figure 10. And the spatial distribution of irrigation entities is shown in figure G6 of appendix G. The calibrated irrigation efficiency ranged from 0.50 to 0.86 , with a mean and SD of 0.72 and 0.09 , respectively. Many of the irrigation entities south of Bellevue had relatively small irrigation efficiencies, which may have resulted from larger farms and fields being located in these entities, with more water being lost in the delivery system.

Areal recharge (including groundwater recharge from infiltration basins and Bypass Canal seepage) volumetric flow rates were specified for each active cell in model layer 1 (fig. 2A) and for each monthly stress period. Total areal recharge during 1995-2010 is shown in figure 11. Flow rates ranged from $-5.0 \times 10^{4}$ to $1.3 \times 10^{6} \mathrm{~m}^{3} / \mathrm{d}$ (or $-1.5 \times 10^{4}$ to $3.7 \times 10^{5}$ acre-ft/yr), with a mean and SD of $3.3 \times 10^{5} \mathrm{~m}^{3} / \mathrm{d}\left(1.0 \times 10^{5}\right.$ acre-ft/yr $)$ and $3.0 \times 10^{5} \mathrm{~m}^{3} / \mathrm{d}$ $\left(9.0 \times 10^{4} \mathrm{acre}-\mathrm{ft} / \mathrm{yr}\right)$, respectively. 
Table 4. Irrigation efficiencies applied to each irrigation entity in the groundwater-flow model domain, Wood River Valley aquifer system, south-central Idaho.

[Irrigation entity: Local name used in this study. Entity No.: Identifier used to locate the irrigation entity in figure 10. Eff: irrigation efficiency, a dimensionless quantity. Entry in bold indicates a calibrated value. A non-bold entry indicates an estimated value that was not included in the model calibration process. NA, not applicable]

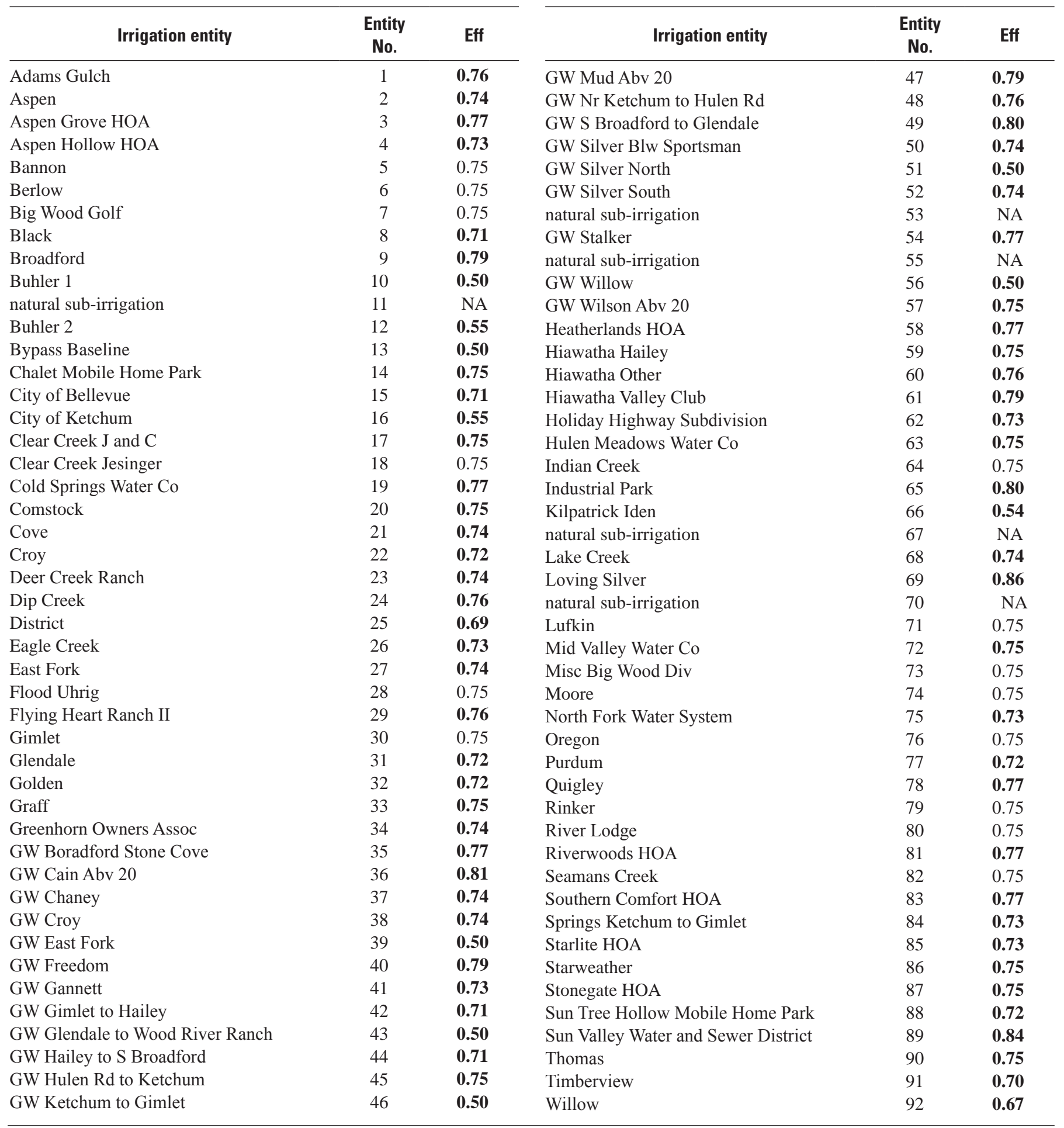




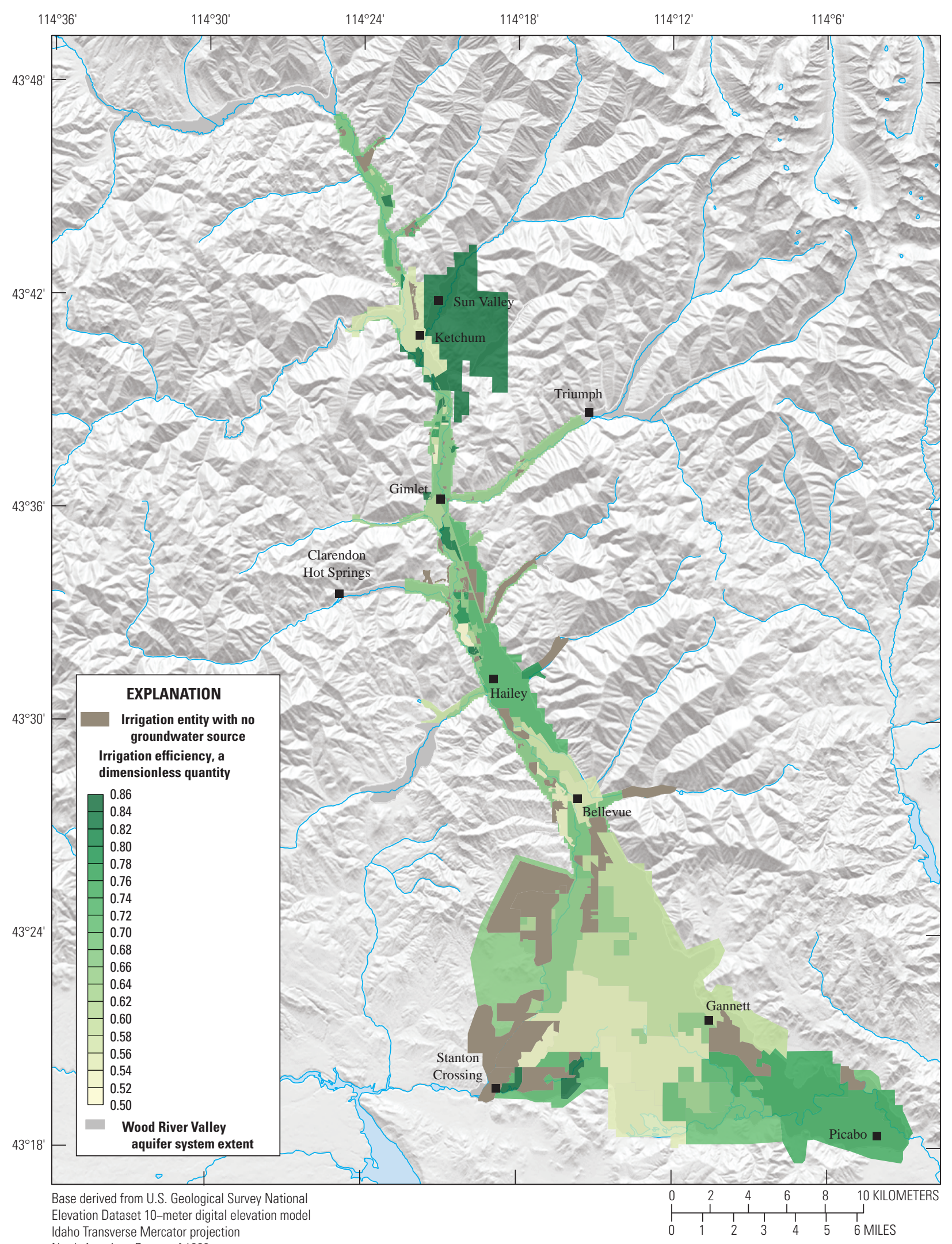

North American

Figure 10. Spatial distribution of calibrated irrigation efficiency in the groundwater-flow model domain, Wood River Valley aquifer system, south-central Idaho. 


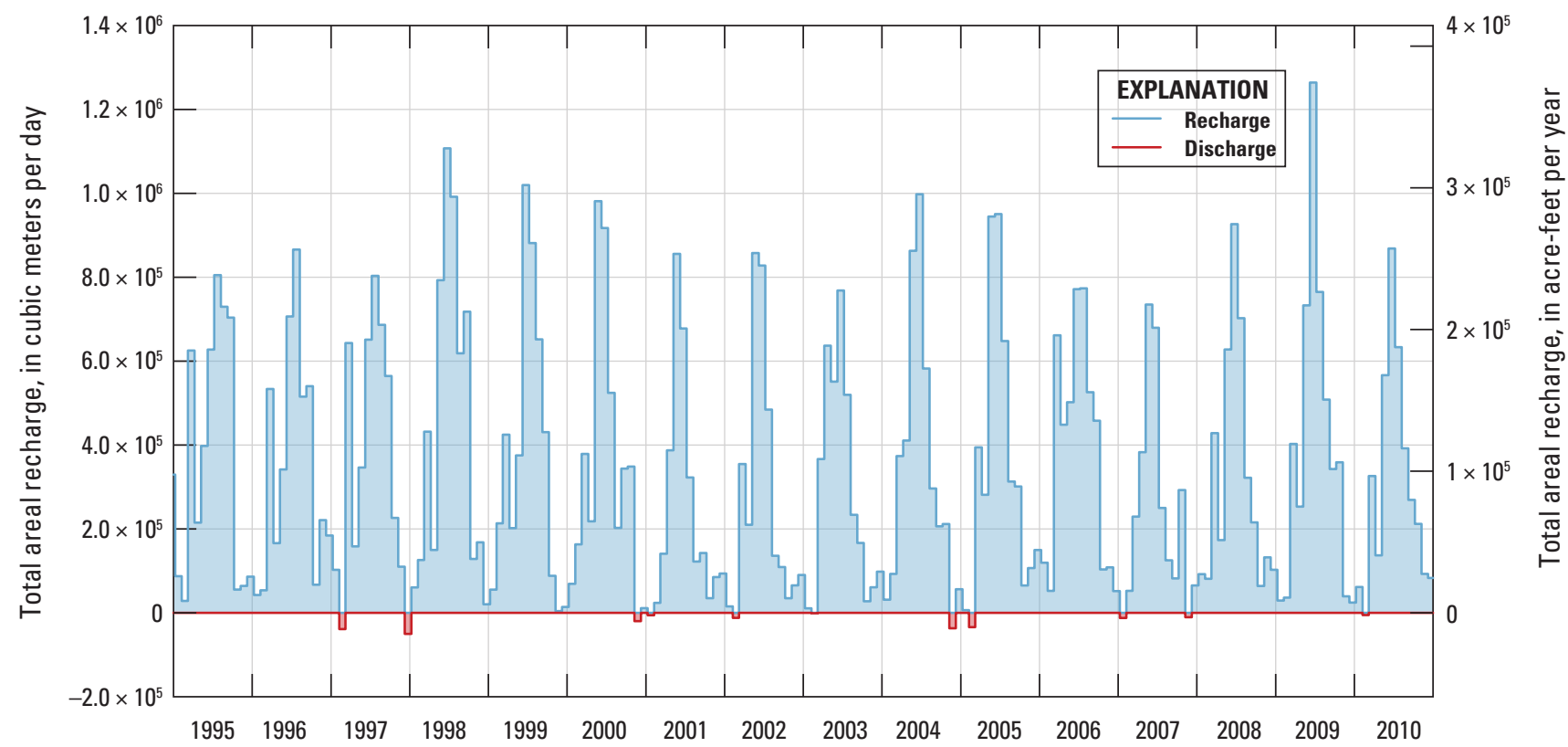

Figure 11. Total areal recharge in the Wood River Valley aquifer system, south-central Idaho, 19952010.

\section{Groundwater Flow Across the Outlet Boundaries}

Groundwater leaving the aquifer system through the Stanton Crossing and Silver Creek outlet boundaries was represented in the model using head-dependent 'drain' cell types (fig. 2). If the hydraulic head (head) in a model cell with a drain boundary condition is less than a certain elevation threshold, the flow rate decreases to zero; therefore, these boundary cells will only allow groundwater to leave the aquifer system. For head values greater than the elevation threshold, groundwater discharge equals the hydraulic conductance of the interface between the aquifer and the drain cell multiplied by the head quantity in excess of the elevation threshold (drain conductance). The assumed elevation thresholds for the Stanton Crossing and Silver Creek outlet boundaries are 1,461 $\mathrm{m}(4,793 \mathrm{ft})$ and 1,450 $\mathrm{m}(4,757 \mathrm{ft})$ (table 5), at locations corresponding to the midpoint of aquifer thickness at these boundaries, respectively.

A drain conductance was assigned to each model layer of the outlet boundary (model layer 1 at Stanton Crossing and layers 1-3 at Silver Creek). The lower and upper bounds on drain conductance were specified at $1 \times 10^{-10}$ and $1 \times 10^{10} \mathrm{~m}^{2} / \mathrm{d}$, respectively, allowing for a very wide range of outflow conditions to be considered during model calibration. The starting values for drain conductance were $210 \mathrm{~m}^{2} / \mathrm{d}$ at the Stanton Crossing outlet boundary and $152 \mathrm{~m}^{2} / \mathrm{d}$ (identical in all three model layers) at the Silver Creek boundary. Calibrated values of drain conductance are shown in table 5 . At the Silver Creek outlet boundary, estimates of drain conductance in model layers 1 and 2 (at 0.9 and $7.5 \mathrm{~m}^{2} / \mathrm{d}$, respectively) were relatively small in comparison to the estimated value for model layer 3 (at $2.0 \times 10^{6} \mathrm{~m}^{2} / \mathrm{d}$ ). This difference is attributed to the simulated water table remaining primarily within model layers 2 and 3 near the outlet boundary, where steep watertable gradients form just prior to entering the larger Eastern Snake River Plain aquifer.

Table 5. Drain conductance and elevation threshold for groundwater outlet boundaries, Wood River Valley aquifer system, south-central Idaho.

[Drain conductance: Hydraulic conductance of the interface between the aquifer and the drain. Elevation threshold: Elevation of the drain. Abbreviations: $\mathrm{m}$, meter; $\mathrm{m}^{2} / \mathrm{d}$, square meter per day. NAVD88; North American Vertical Datum of 1988]

\begin{tabular}{lccc}
\hline Outlet boundary & $\begin{array}{c}\text { Model } \\
\text { layer }\end{array}$ & $\begin{array}{c}\text { Drain } \\
\text { conductance } \\
\left.\text { ( } \mathbf{m}^{2} / \mathbf{d}\right)\end{array}$ & $\begin{array}{c}\text { Elevation } \\
\text { threshold } \\
\text { (m above NAVD 88) }\end{array}$ \\
\hline Stanton Crossing & 1 & $2.8 \times 10^{4}$ & 1,461 \\
Silver Creek & 1 & $8.8 \times 10^{-1}$ & 1,450 \\
& 2 & 7.5 & 1,450 \\
& 3 & $2.0 \times 10^{6}$ & 1,450 \\
\hline
\end{tabular}


During the model-calibration process, preferred conditions were specified for the average discharge across each outlet boundary. The model was calibrated using the Bartolino and Adkins (2012) average discharge estimates of $1,000 \mathrm{~m}^{3} / \mathrm{d}$ (300 acre-ft/yr) for Stanton Crossing and $14,000 \mathrm{~m}^{3} / \mathrm{d}(4,100$ acre-ft/yr) for Silver Creek as calibration targets. Simulated groundwater discharge across the Stanton Crossing and Silver Creek outlet boundaries is shown in figure 12. For the Stanton Crossing outlet boundary (fig. 12A), groundwater discharge ranged from 660 to $1,400 \mathrm{~m}^{3} / \mathrm{d}$ (190 to 410 acre-ft/yr), with a mean and SD of $960 \mathrm{~m}^{3} / \mathrm{d}$ (280 acre-ft/yr) and $140 \mathrm{~m}^{3} / \mathrm{d}$ (42 acre-ft/yr). For the Silver Creek outlet boundary (fig. 12B), groundwater discharge ranged from $2.1 \times 10^{4}$ to $4.1 \times 10^{4} \mathrm{~m}^{3} / \mathrm{d}\left(6.4 \times 10^{3}\right.$ to $1.2 \times 10^{4}$ acre- $\left.\mathrm{ft} / \mathrm{yr}\right)$, with a mean and SD of $3.2 \times 10^{4} \mathrm{~m}^{3} / \mathrm{d}\left(9.5 \times 10^{3}\right.$ acre-ft/yr) and $4.6 \times 10^{3} \mathrm{~m}^{3} / \mathrm{d}\left(1.4 \times 10^{3}\right.$ acre-ft/yr). Simulated groundwater discharge at Silver Creek is more sensitive to dry years (2001-05), compared with simulated groundwater discharge at Stanton Crossing.
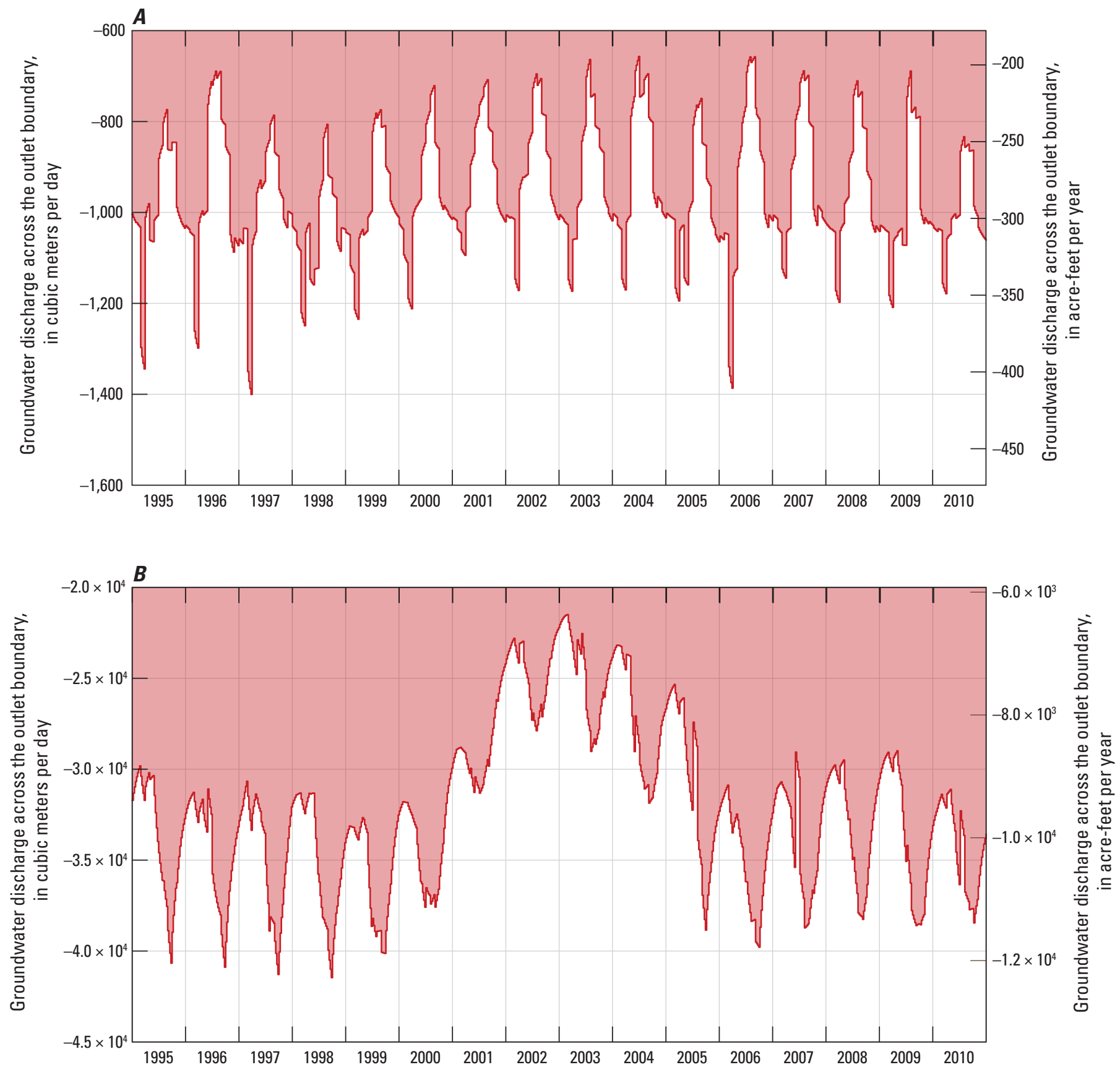

Figure 12. Simulated groundwater discharge across the $(A)$ Stanton Crossing and $(B)$ Silver Creek outlet boundaries, Wood River Valley aquifer system, south-central Idaho, 1995-2010. 


\section{Stream-Aquifer Flow Exchange in River Reaches}

Stream-aquifer flow exchange in the WRV was represented in the model using head-dependent 'river' cell types (fig. 2). If the head in a river cell is below the bottom of the riverbed, water enters the aquifer from the river (also known as aquifer recharge or river loss) at a constant rate. Furthermore, groundwater recharge occurs when the head is above the bottom of the riverbed and below the stream-stage elevation, albeit at a reduced rate that is dependent on the hydraulic conductance of the riverbed sediments (riverbed conductance) and the head difference between streamstage elevation and the head in the cell. For head values that are greater than or equal to the stream-stage elevation, groundwater is discharged from the aquifer at a reduced rate dependent on riverbed conductance and the difference between aquifer head in the cell and the head in the river. A description of the process used to estimate river geometry parameters (that is, the riverbed bottom elevation and riverbed thickness) and stream-stage elevation is provided in section, "Stream-Aquifer Flow Exchange in River Reaches" in appendix D.
To simplify the structural complexity of rivers in the model domain, the WRV river system was discretized into 5 river reaches (appendix $\mathrm{H}$, fig. H7) and 22 river subreaches (table 6, fig. 13). A river reach is defined as a continuous piece of surface water with similar hydrologic characteristics and a river subreach is defined in this report as a section of a stream that has a uniform riverbed conductance and riverbed thickness. The riverbed conductance of a subreach was the only river parameter varied during the modelcalibration process. The lower and upper bounds on riverbed conductance were specified at $1 \times 10^{-10}$ and $1 \times 10^{10} \mathrm{~m}^{2} / \mathrm{d}$, respectively, allowing for a very wide range of stream-aquifer flow-exchange rates to be considered during model calibration. The starting value for riverbed conductance in a river cell ranged between 1,890 and $5,669 \mathrm{~m}^{2} / \mathrm{d}$. Calibrated values of riverbed conductance are shown in table 6 and figure 13. The riverbed conductance ranged from $1 \mathrm{~m}^{2} / \mathrm{d}$ in the Big Wood River, Hailey to North Broadford subreach (No. 5) to 291,579 $\mathrm{m}^{2} / \mathrm{d}$ in the Willow Creek subreach (No. 11), with a mean and SD of 50,307 and 98,569 $\mathrm{m}^{2} / \mathrm{d}$, respectively.

Table 6. Calibrated riverbed conductance in river subreaches of the Wood River Valley aquifer system, south-central Idaho.

[Subreach No: Identifier used to locate river subreaches in figure 13. Reach No: Identifier for river reaches. Riverbed conductance: Average hydraulic conductance of the riverbed sediments. Abbreviations: $\mathrm{m}^{2} / \mathrm{d}$, square meter per day; -, a river subreach that is not associated with a river reach]

\begin{tabular}{lccr}
\hline \multicolumn{1}{c}{ River subreach } & $\begin{array}{c}\text { Subreach } \\
\text { No. }\end{array}$ & $\begin{array}{c}\text { Reach } \\
\text { No. }\end{array}$ & $\begin{array}{r}\text { Riverbed } \\
\text { conductance } \\
\text { (m²/d) }\end{array}$ \\
\hline Big Wood, near Ketchum to Hulen Road & 1 & 1 & 10,536 \\
Big Wood, Hulen Road to Ketchum & 2 & 1 & 11,374 \\
Big Wood, Ketchum to Gimlet & 3 & 1 & 498 \\
Big Wood, Gimlet to Hailey & 4 & 1 & 4 \\
Big Wood, Hailey to North Broadford & 5 & 2 & 1 \\
Big Wood, North Broadford to South Broadford & 6 & 2 & 2 \\
Big Wood, South Broadford to Glendale & 7 & 2 & 51,418 \\
Big Wood, Glendale to Sluder & 8 & 2 & 8,355 \\
Big Wood, Sluder to Wood River Ranch & 9 & 2 & 339 \\
Big Wood, Wood River Ranch to Stanton Crossing & 10 & 2 & 49,114 \\
Willow Creek & 11 & 3 & 291,579 \\
Big Wood, Stanton Crossing to near Bellevue & 12 & - & 251,168 \\
Buhler Drain above Highway 20 & 13 & 4 & 23,543 \\
Patton Creek above Highway 20 & 14 & 4 & 928 \\
Cain Creek above Highway 20 & 15 & 4 & 128 \\
Chaney Creek above Highway 20 & 16 & 4 & 269 \\
Mud Creek above Highway 20 & 17 & 4 & 336 \\
Wilson Creek above Highway 20 & 18 & 4 & 78 \\
Grove Creek above Highway 20 & 19 & 4 & 1,401 \\
Loving Creek above Highway 20 & 20 & 4 & 41,410 \\
spring creeks below Highway 20 & 21 & 4 & 297 \\
Silver Creek, Sportsman Access to near Picabo & 22 & 5 & 3 \\
\hline
\end{tabular}




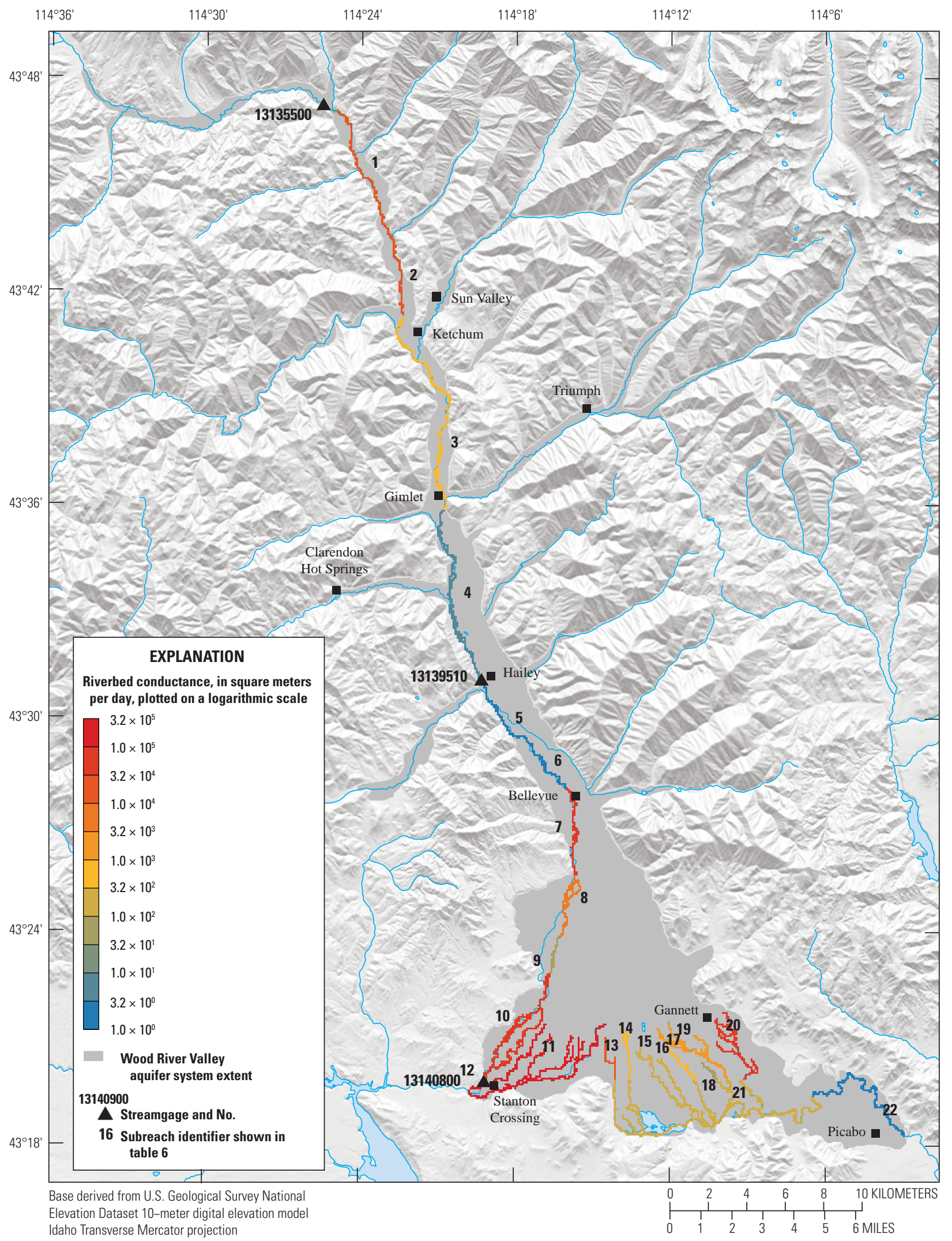

Idaho Transverse Mercator projection

Figure 13. Spatial distribution of the calibrated riverbed conductance in the groundwater-flow model domain, Wood River Valley aquifer system, south-central Idaho. River subreach identifiers are used as a cross reference with data in table 6. 
The cumulative sum of simulated stream-aquifer flow-exchange values in river cells (cells shown in fig. 2A) is shown in figure 14. Recall that negative values of streamaquifer flow exchange indicate aquifer discharge (or stream gains), and positive values indicate groundwater recharge (or stream losses). Flow-exchange values range from $-8.4 \times 10^{5}$ to $3.8 \times 10^{5} \mathrm{~m}^{3} / \mathrm{d}\left(-343\right.$ to $\left.155 \mathrm{ft}^{3} / \mathrm{s}\right)$, with a mean and SD of $-2.5 \times 10^{5} \mathrm{~m}^{3} / \mathrm{d}\left(-102 \mathrm{ft}^{3} / \mathrm{s}\right)$ and $1.6 \times 10^{5} \mathrm{~m}^{3} / \mathrm{d}\left(65 \mathrm{ft}^{3} / \mathrm{s}\right)$, respectively. In general, the WRV river system is gaining water from the aquifer system; that is, groundwater is contributing to surface water.

The upstream and downstream boundaries of a river reach typically coincide with the location of a streamgage with continuous records. Mean monthly stream-aquifer flow exchange along river reaches were calculated using a flow-difference method, details of which are provided in appendix H. Comparisons between measured and simulated stream-aquifer flow exchange over time are shown for all river reaches in figures 15-17.

River reaches along the Big Wood River include the Near Ketchum to Hailey reach (reach No. 1; fig. 15A) and Hailey to Stanton Crossing reach (reach No. 2; fig. 15B). For the Near Ketchum to Hailey river reach, stream-aquifer flow-exchange measurements were unavailable for May-September because of apparent ungaged surface flow entering the river. Flowexchange values were negative and indicate that the aquifer is losing water to the stream reach during the simulation period. Large aquifer losses occur during the spring of each year and are the result of increased infiltration and recharge from snowmelt increasing the water table. The magnitude of these aquifer losses is determined in part by the timing of snowmelt and the fraction that recharges the aquifer. The model typically underpredicts the losses; the measured reach losses possibly contain ungaged surface runoff or streamflow, or perhaps the assumptions imposed regarding the rates and timing of snowmelt infiltration are incorrect. The model shows a good match between measured and simulated December-March aquifer losses to the streams: differences are typically less than $2.5 \times 10^{4} \mathrm{~m}^{3} / \mathrm{d}\left(10 \mathrm{ft}^{3} / \mathrm{s}\right)($ fig. $15 \mathrm{~A})$.

For the Hailey to Stanton Crossing river reach (reach No. 2; fig. 15B), stream-aquifer flow-exchange measurements were unavailable during 1995 and most of 1996; the streamgage at Stanton Crossing near Bellevue (13140800) began operation in October 1996. Flowexchange measurements during summer 1997, 1998, and 1999, are likely the result of measurement error at the Hailey (13139510) and Stanton Crossing near Bellevue (13140800) streamgages and diversion measurement error. The aquifer is primarily gaining along this reach during the model-simulation period. The model provides a good fit with measured flowexchange values in the Hailey to Stanton Crossing river reach (fig. 15B).

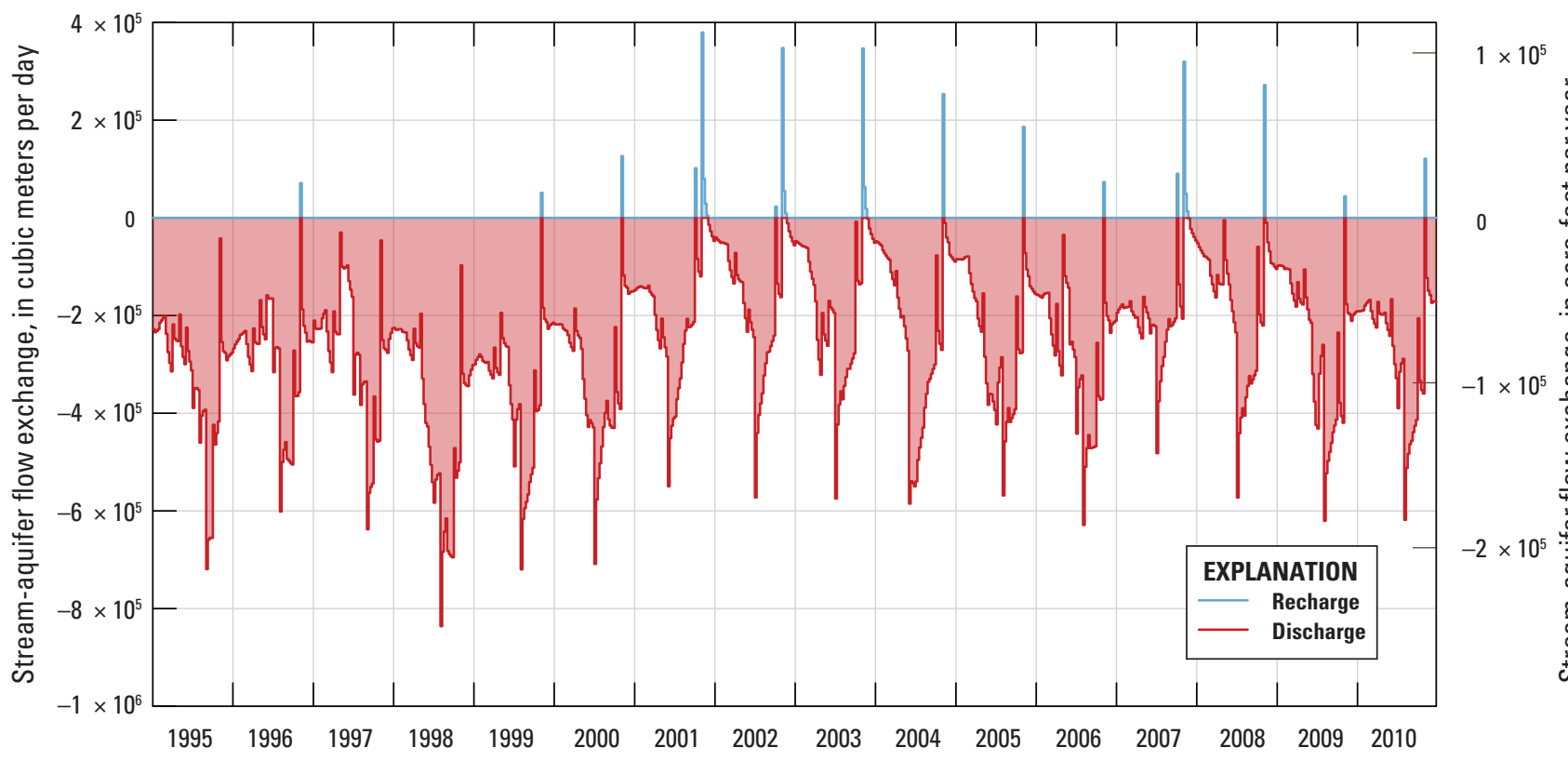

Figure 14. Simulated stream-aquifer flow exchange in the groundwater-flow model domain, Wood River Valley aquifer system, south-central Idaho, 1995-2010. 


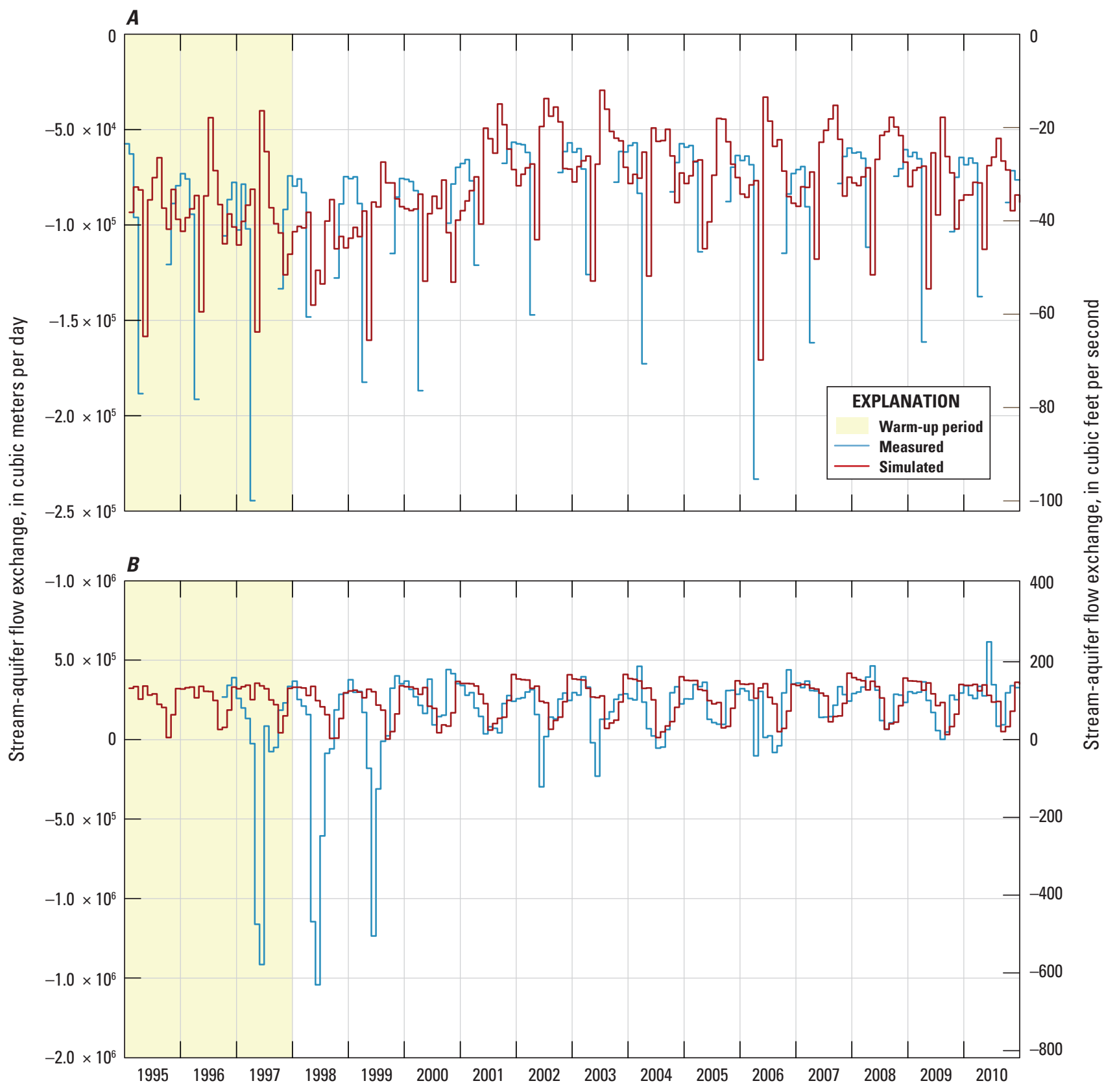

Figure 15. Measured and simulated stream-aquifer flow exchange in the Big Wood River, $(A)$ near Ketchum to Hailey river reach, and $(B)$ Hailey to Stanton Crossing river reach, Wood River Valley aquifer system, south-central Idaho, 1995-2010. Negative values of stream-aquifer flow exchange indicate aquifer discharge (or stream gains), and positive values indicate groundwater recharge (or stream losses). 
For the Willow Creek river reach (reach No. 3; fig. 16), stream-aquifer flow-exchange measurements were unavailable during 1995-June 2000. Flow-exchange values were always negative and indicate that the aquifer was losing water to the stream during the simulation period. The model matches the timing of the seasonal fluctuations well but tends to underpredict the seasonal amplitude (fig. 16).

For Silver Creek, above Sportsman Access (reach No. 4), the stream-aquifer flow-exchange values were always negative and indicate that the aquifer was continuously losing water to the stream during the simulation period. The model matches the timing of the seasonal fluctuations well and generally matches the amplitude, although the model underpredicted the decrease in aquifer losses during autumn 2001 and 2002, and the large magnitude aquifer losses during the summer 2006 and 2007 (fig. 17A).

For the Silver Creek, Sportsman Access to near Picabo reach (reach No. 5; fig. 17B), the measured aquifer losses were estimated to be near zero and the model adequately matched this value (fig. 17B). The temporally constant simulated stream-aquifer flow exchange was attributed to the aquifer not being hydraulically connected to the stream, and stage changes being modest. Furthermore, field measurements indicate minor (if any) aquifer gains in this river reach.

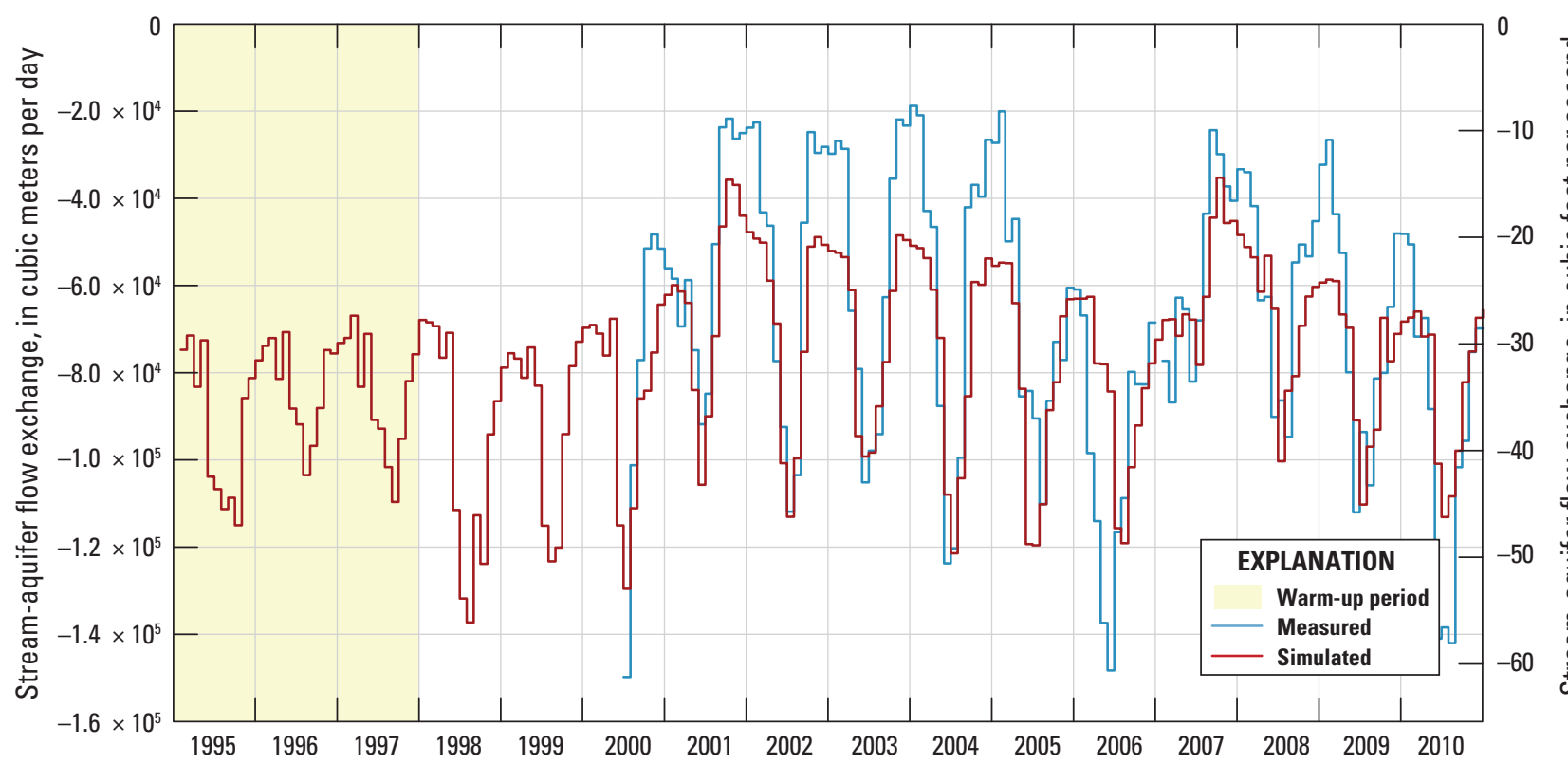

Figure 16. Measured and simulated stream-aquifer flow exchange in the Willow Creek river reach, Wood River Valley aquifer system, south-central Idaho, 1995-2010. 


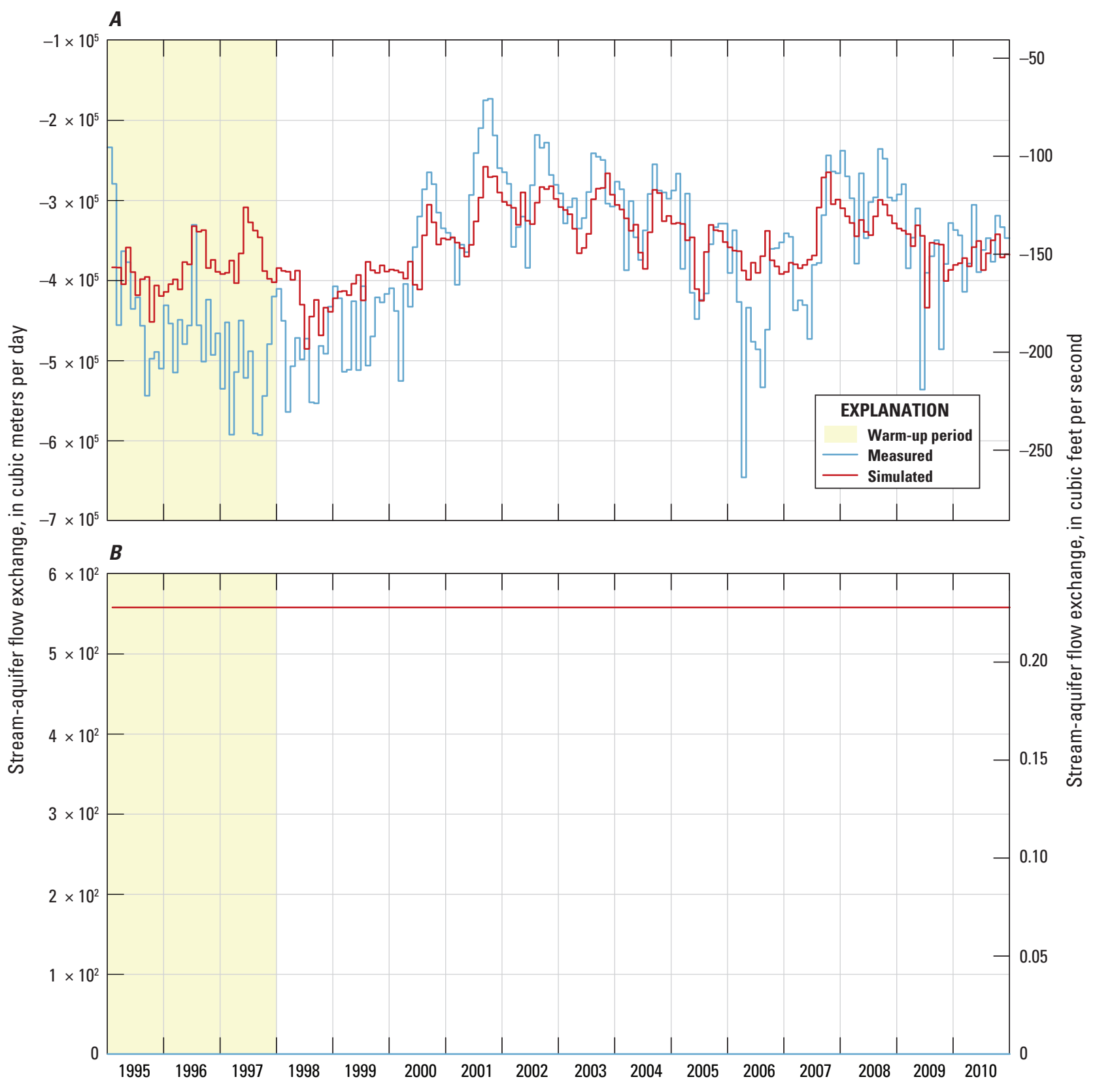

Figure 17. Measured and simulated stream-aquifer flow exchange along $(A)$ the Silver Creek, above Sportsman Access river reach; and (B) Silver Creek, Sportsman Access to near Picabo river reach, Wood River Valley aquifer system, south-central Idaho, 1995-2010. 
The residual of a stream-aquifer flow exchange for a selected month is defined as the difference between the measured and simulated values. Scatterplots of the residuals compared to simulated values along each of the river reaches are shown in figure 18. Descriptive statistics for streamaquifer flow-exchange residuals along each river reach are shown in table 7. Positive values for the residual indicate that the simulated value was too small, and negative values indicate the simulated value was too large, whereas zero indicates an exact match with the measurement. Residual values were largest in the Big Wood River, Hailey to Stanton Crossing river reach (No. 2), ranging from $-1.8 \times 10^{6}$ to $3.6 \times 10^{5} \mathrm{~m}^{3} / \mathrm{d}\left(-735\right.$ to $\left.147 \mathrm{ft}^{3} / \mathrm{s}\right)$ (fig. $18 \mathrm{~B}$, table 7$)$. Surface water in the Big Wood River between the Hailey (13139510) and Stanton Crossing (13140800) streamgages typically is hydraulically disconnected; this is because of seepage losses and irrigation diversions that result in substantial decreases in streamflow between these sites. Furthermore, the river channel is seasonally dry between Glendale Road and Wood River Ranch when the water district diverts the entire river flow into the Bypass Canal. Because a flow-difference method was used to estimate the stream-aquifer flow exchange along this river reach, the large uncertainties associated with irrigation diversions and return flow to the Big Wood River are attributed to the large residual values for this reach.
Using a flow-difference method, the stream-aquifer flow exchanges along river subreaches (table 6, fig. 13) were estimated using streamflow measurements recorded during August and October 2012, and March 2013 (Bartolino, 2014). These flow-exchange estimates occurred outside the modelcalibration period (1998-2010); therefore, to include this dataset in the model-calibration process, it was necessary to relate these values to estimates of mean monthly streamaquifer flow exchange along river reaches during the 20002010 time period. The ratios between subreach flow-exchange estimates and their corresponding reach values were calculated for August, October, and March. This calculation is described in more detail in appendix $\mathrm{H}$. The residual of a streamaquifer flow-exchange ratio for a selected month is defined as the difference between measured and simulated values. Scatterplots of the residuals compared to simulated ratios during March, August, and October are shown in figure 19.

The March data form the best match between measured and simulated values, and likely is owing to the minimal anthropogenic water use during this month (appendix $\mathrm{H}$ ). One of the factors affecting the ability to match these targets is that averaged August, October, and March values from 2000 through 2010 are a poor proxy for data collected in August and October 2012, and March 2013. This is because the distributions of subreach gains are affected by weather and local water-management practices that are not necessarily repeated every calendar year.

Table 7. Descriptive statistics for the residual of stream-aquifer flow exchange along river reaches in the Wood River Valley aquifer system, south-central Idaho.

[Reach No.: Identifier for the river reach-No. 1 is Big Wood River, near Ketchum to Hailey; No. 2 is Big Wood River, Hailey to Stanton Crossing; No. 3 is Willow Creek; No. 4 is Silver Creek, above Sportsman Access; No. 5 is Silver Creek, Sportsman Access to near Picabo]

\begin{tabular}{lccccc}
\hline \multirow{2}{*}{$\begin{array}{c}\text { Descriptive } \\
\text { statistics }\end{array}$} & \multicolumn{5}{c}{ Residual of stream-aquifer flow exchange, in cubic meters per day } \\
\cline { 2 - 6 } & $\begin{array}{c}\text { Reach } \\
\text { No. 1 }\end{array}$ & $\begin{array}{c}\text { Reach } \\
\text { No. 2 }\end{array}$ & $\begin{array}{c}\text { Reach } \\
\text { No. 3 }\end{array}$ & $\begin{array}{c}\text { Reach } \\
\text { No. 4 }\end{array}$ & $\begin{array}{c}\text { Reach } \\
\text { No. 5 }\end{array}$ \\
\hline Minimum & $-1.6 \times 10^{5}$ & $-1.8 \times 10^{6}$ & $-6.4 \times 10^{4}$ & $-2.6 \times 10^{5}$ & $-5.6 \times 10^{2}$ \\
1st quartile & $-1.8 \times 10^{4}$ & $-1.3 \times 10^{5}$ & $-3.8 \times 10^{3}$ & $-5.8 \times 10^{4}$ & $-5.6 \times 10^{2}$ \\
Median & $9.4 \times 10^{3}$ & $-4.1 \times 10^{4}$ & $9.2 \times 10^{3}$ & $-2.8 \times 10^{3}$ & $-5.6 \times 10^{2}$ \\
Mean & $-5.8 \times 10^{3}$ & $-9.0 \times 10^{4}$ & $6.5 \times 10^{3}$ & $-2.0 \times 10^{4}$ & $-5.6 \times 10^{2}$ \\
3rd quartile & $1.8 \times 10^{4}$ & $5.2 \times 10^{4}$ & $2.0 \times 10^{4}$ & $3.5 \times 10^{4}$ & $-5.6 \times 10^{2}$ \\
Maximum & $5.1 \times 10^{4}$ & $3.6 \times 10^{5}$ & $4.3 \times 10^{4}$ & $1.0 \times 10^{5}$ & $-5.6 \times 10^{2}$ \\
\hline
\end{tabular}




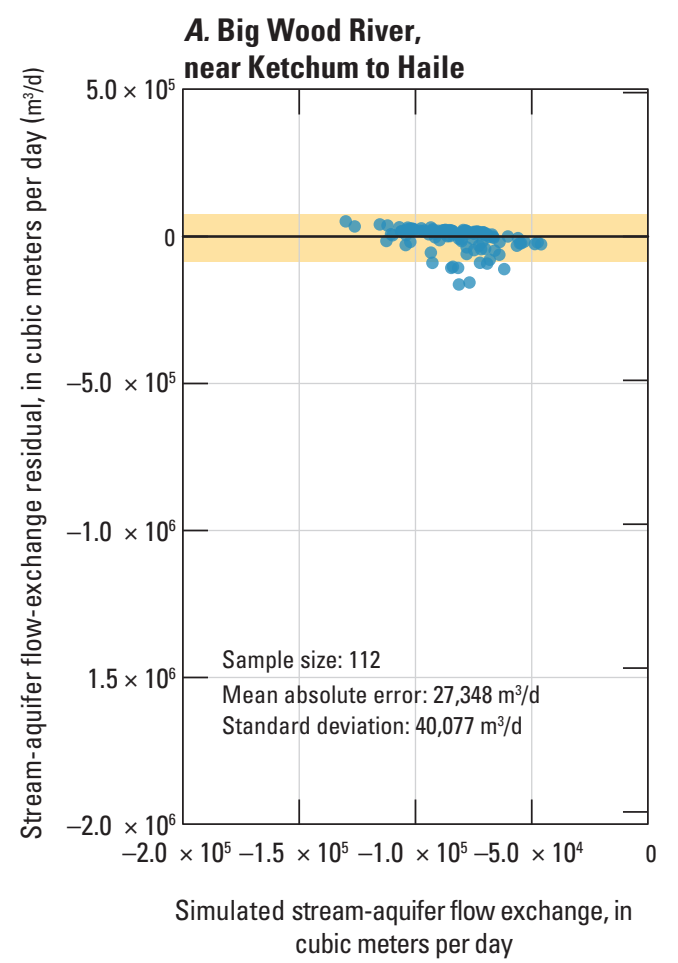

B. Hailey to Stanton Crossing

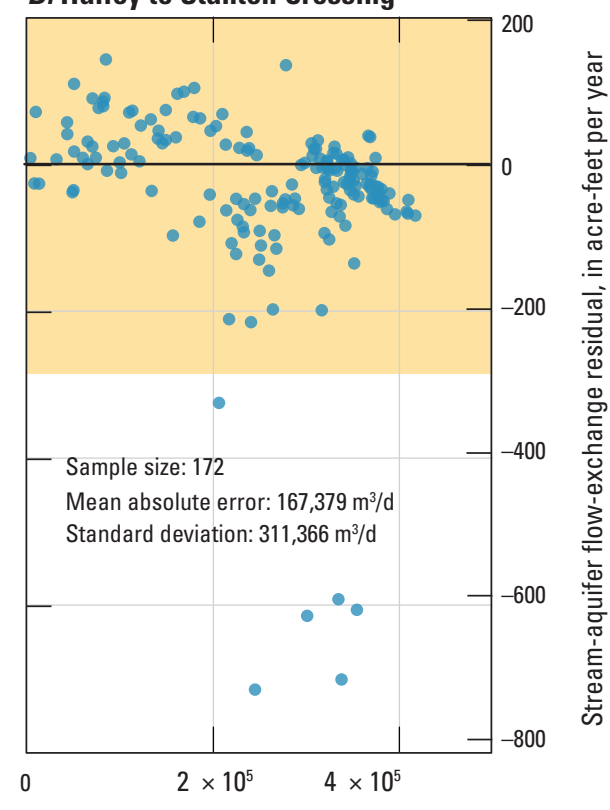

Simulated stream-aquifer flow exchange, in cubic meters per day

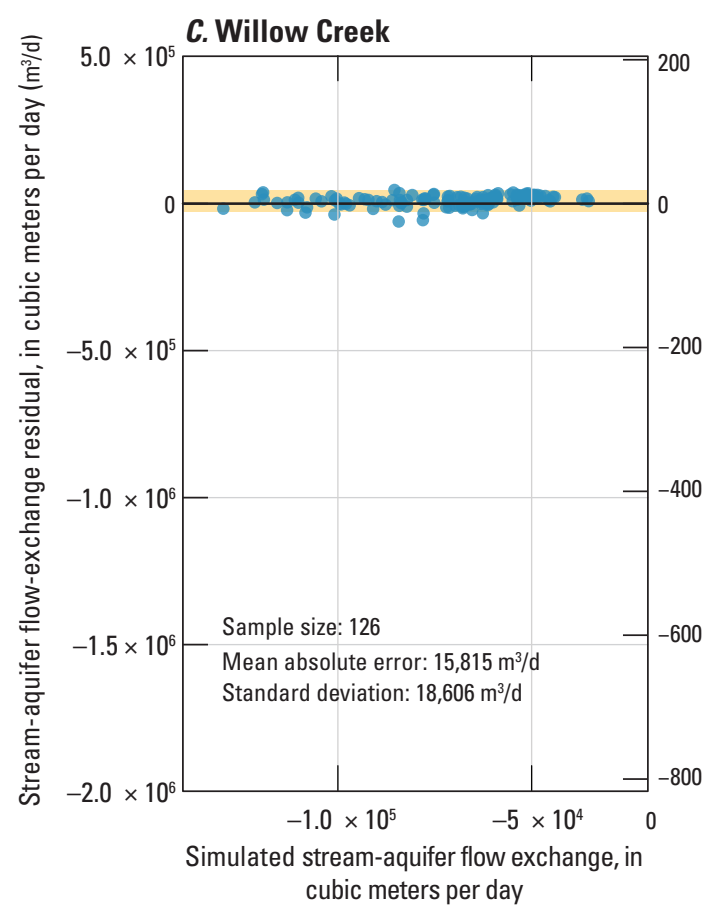

EXPLANATION

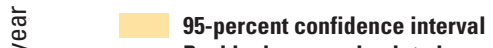
- Residual versus simulated

Figure 18. Mean stream-aquifer flow-exchange residuals along river reaches $(A)$ Big Wood River, near Ketchum to Hailey and $(B)$ Hailey to Stanton Crossing; $(C)$ Willow Creek; $(D)$ Silver Creek, above Sportsman Access; and $(E)$ Silver Creek, Sportsman Access to near Picabo, Wood River Valley aquifer system, south-central Idaho. 

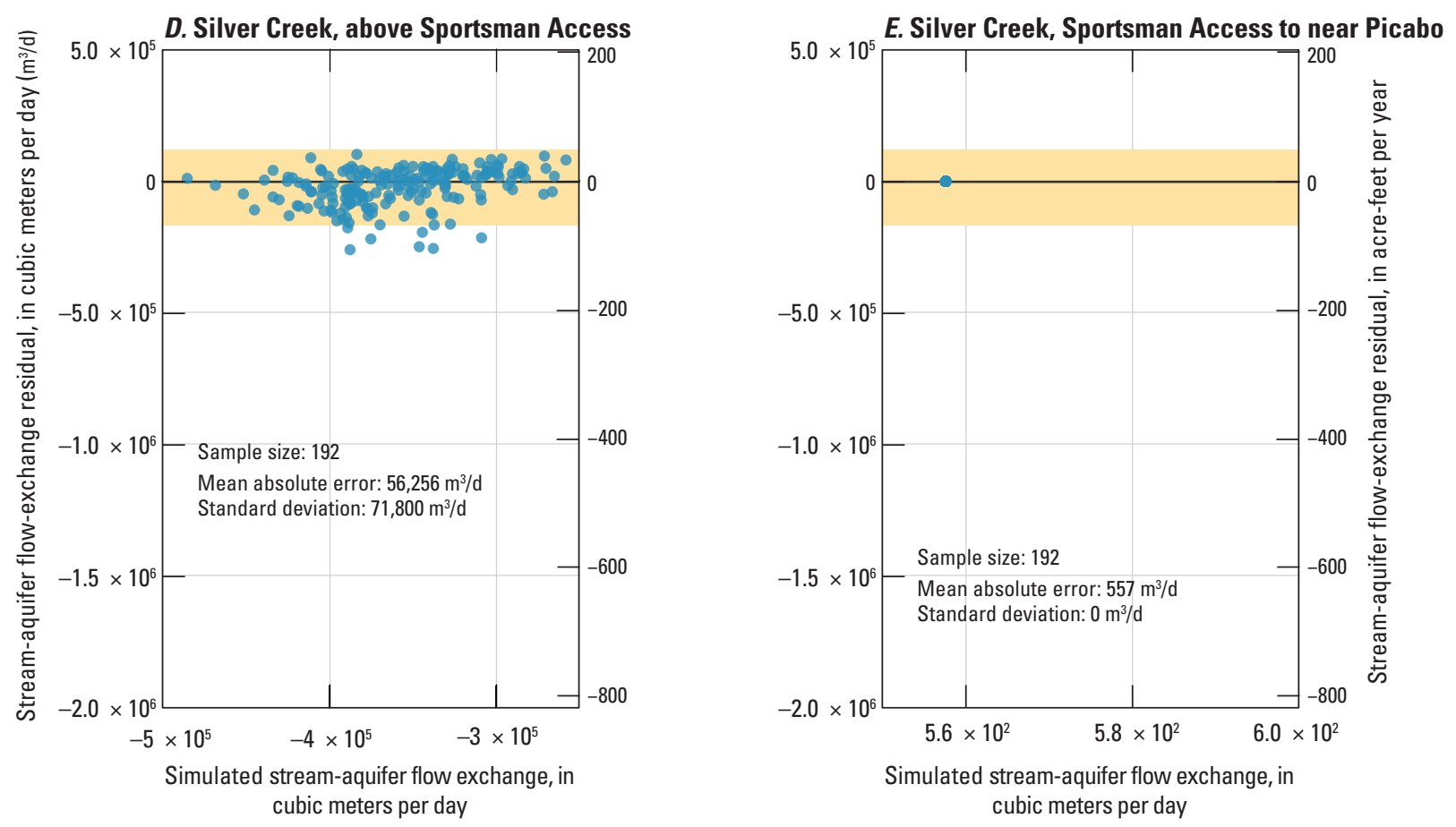

EXPLANATION

95-percent confidence interval

- Residual versus simulated

Figure 18.-Continued 

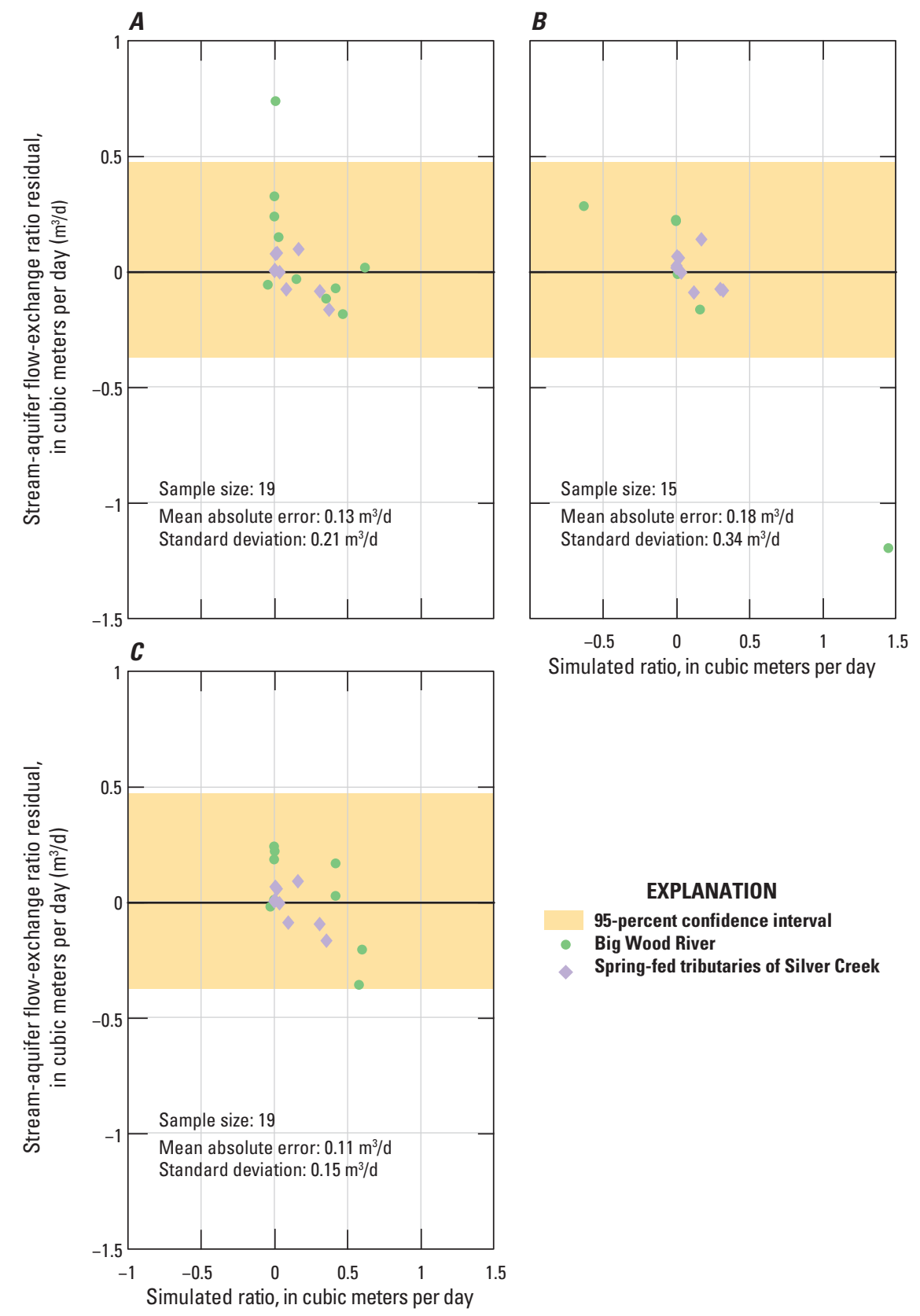

Simulated ratio, in cubic meters per day

\section{EXPLANATION}

95-percent confidence interval

Big Wood River

Spring-fed tributaries of Silver Creek

Figure 19. Mean stream-aquifer flow-exchange ratio residuals for river subreaches during $(A)$ March, $(B)$ August, and $(C)$ October, Wood River Valley aquifer system, south-central Idaho. 


\section{Hydraulic Head}

Hydraulic head (head) is a measure of the fluid pressure above a geodetic datum; in this report, head is represented in units of meters above the North American Vertical Datum of 1988. The numerical groundwater-flow model simulates hydraulic head in every cell of the active model grid (fig. 2) for each of the 768 weekly time steps between 1995 and 2010, as well as an initial steady-state period prior to 1995. Groundwater flow through an aquifer system is the result of water moving from areas of high hydraulic head to areas of low hydraulic head. The direction of horizontal (or longitudinal) flow in an aquifer can be determined using a contour map of the water table (that is, head values in the uppermost unconfined aquifer), where flow is perpendicular to the contour lines. The simulated water table of the WRV aquifer system was represented using model layer 1 heads bounded by the land-surface elevation - head values that exceeded land surface were specified at land surface. The simulated water table in the model area at the end of the last stress period, December 31, 2010, is shown in figure 20. Contour maps interpolated from this simulated water-table surface are shown in figure 21. In general, the simulated pattern of horizontal groundwater movement in the WRV aquifer system is for water to move down valley to the Bellevue fan.

The simulated head distribution (during December 31, 2010), interpolated contour lines, and water table within a vertically exaggerated cross section (transect line shown in fig. 20) are shown in figure 23. The orientation of the cross section generally parallels the flow path for water moving across the Bellevue fan in a southeasterly direction. The cross section shows a large vertical head difference near the low-permeability confining unit (fig. 4), with larger heads in the underlying confined aquifer. Groundwater generally flows into the Bellevue fan deposits under unconfined conditions and either moves into the deep confined aquifer or remains in the shallow unconfined aquifer. Farther downgradient where the confining unit is absent, groundwater flow from the two aquifers merge to become hydraulically connected.

A comparison between simulated and measured water-table contours for the southern part of the WRV is shown in figure 23. The measured water-table contours (Skinner and others, 2007, p. 21, pl. 2) were constructed from 88 groundwater-level measurements distributed non-uniformly throughout the model area. The groundwaterlevel measurements were made by the USGS during October 23-27, 2006, in wells completed in the unconfined aquifer. The simulated water-table contours were interpolated from simulated heads at the center of each cell in model layer 1 during the October 2006 stress period. The water-table contours are reasonably comparable (fig. 23). The geometry and elevation of the water table generally is well simulated by the model, although there are discrepancies in the widest areas of the valley.

Groundwater-level measurements were classified into five well groups that include:

1. USGS groundwater-monitoring network wells,

2. Geolocated driller wells,

3. Public Land Survey System (PLSS)-located driller wells,

4. Sun Valley Water and Sewer District (SVWSD) production wells, and

5. The Nature Conservancy (TNC) groundwatermonitoring network wells.

For each well group, statistical and graphical comparisons were made between the simulated and measured groundwaterlevel data. The number of groundwater-level measurements varied for each well, as did the period-of-record (appendix H, table H1). 


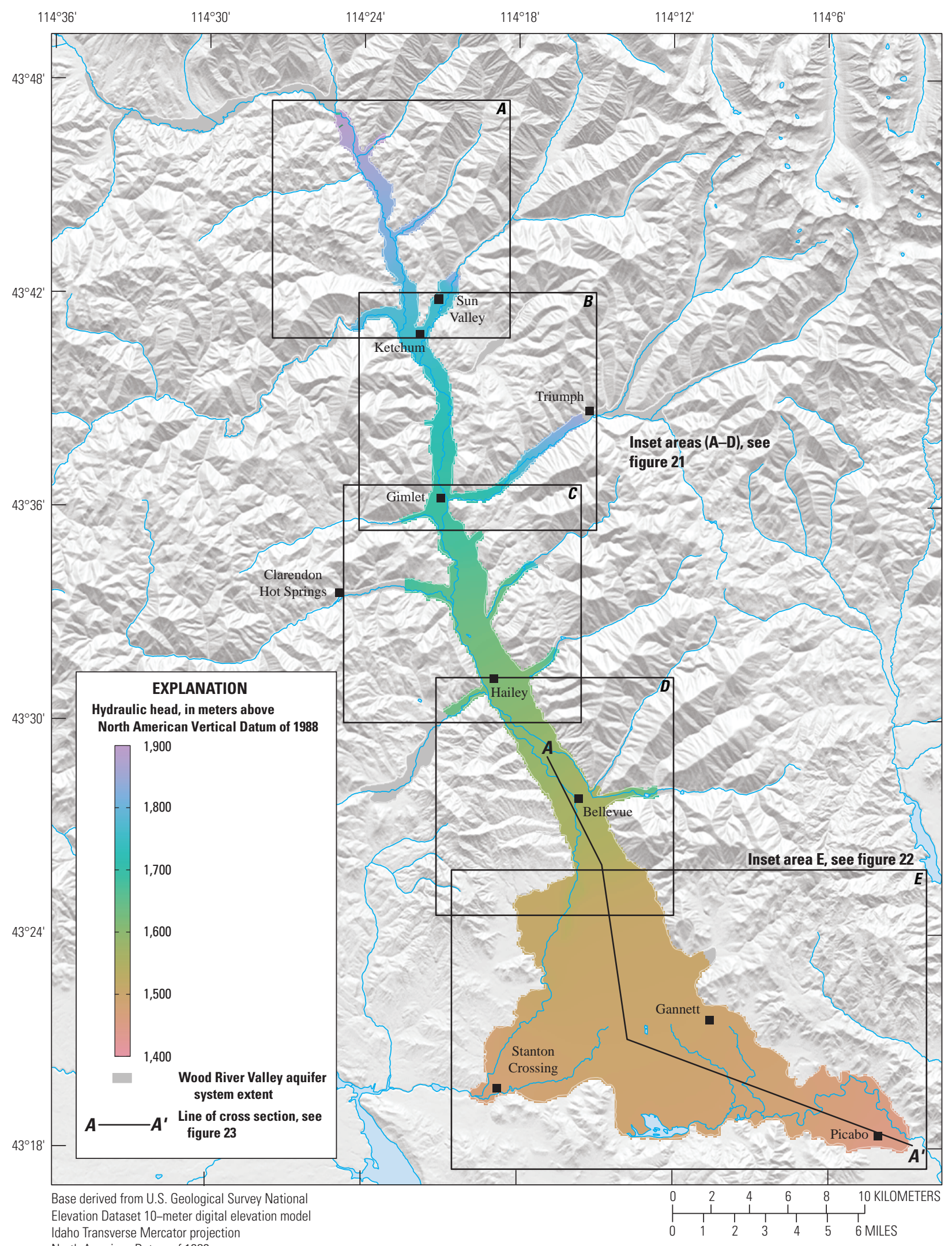

North American Datum of 1983

Figure 20. Simulated hydraulic heads representing the water-table surface in the Wood River Valley aquifer system, south-central Idaho, December 31, 2010. 

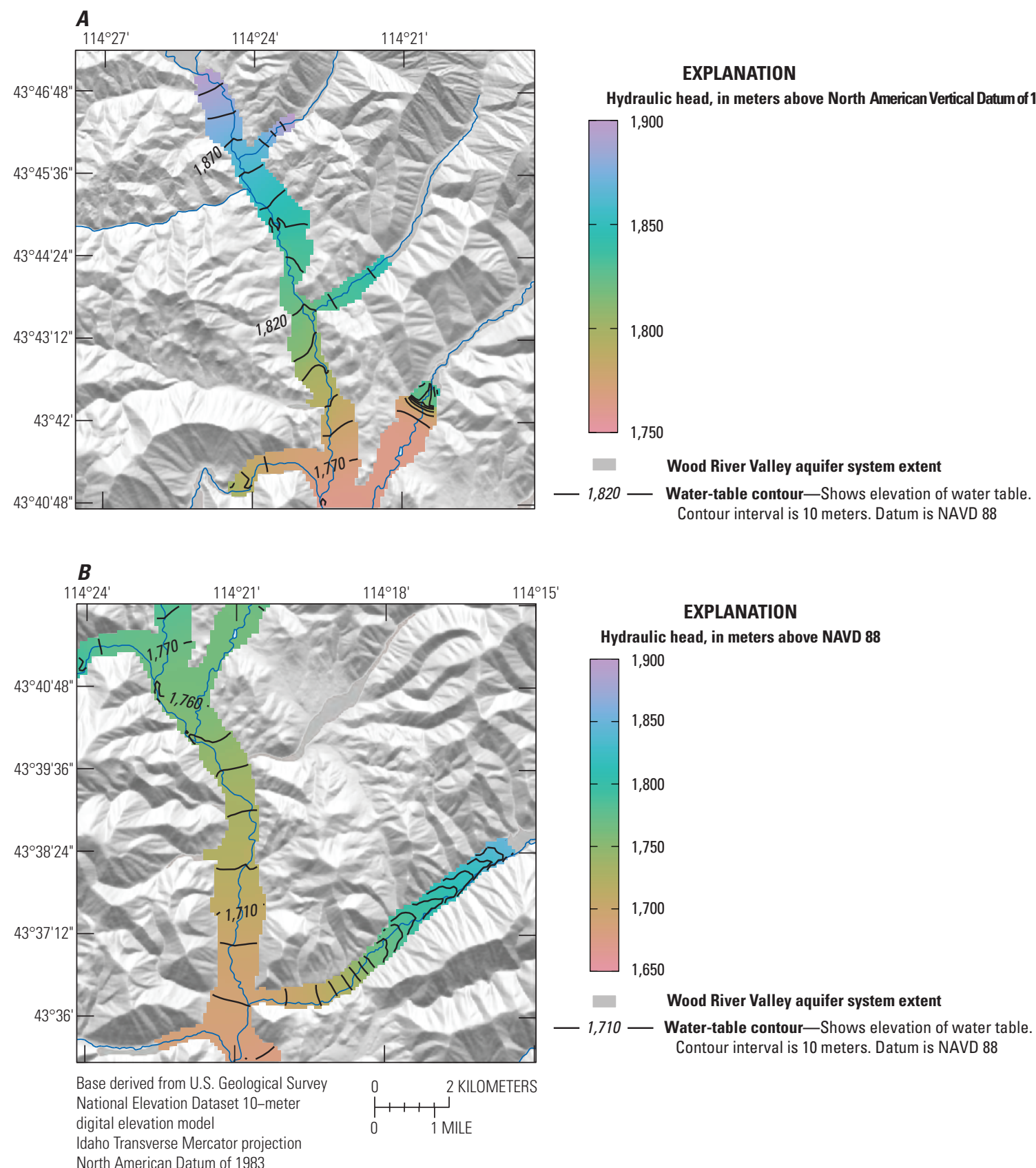

Figure 21. Simulated hydraulic heads representing the water-table surface in the areas $(A)$ north of Ketchum, $(B)$ south of Ketchum and north of Gimlet, $(C)$ south of Gimlet and north of Hailey, $(D)$ south of Hailey and north of Bellevue, and $(E)$ south of Bellevue, Wood River Valley aquifer system, south-central Idaho, December 2010. 

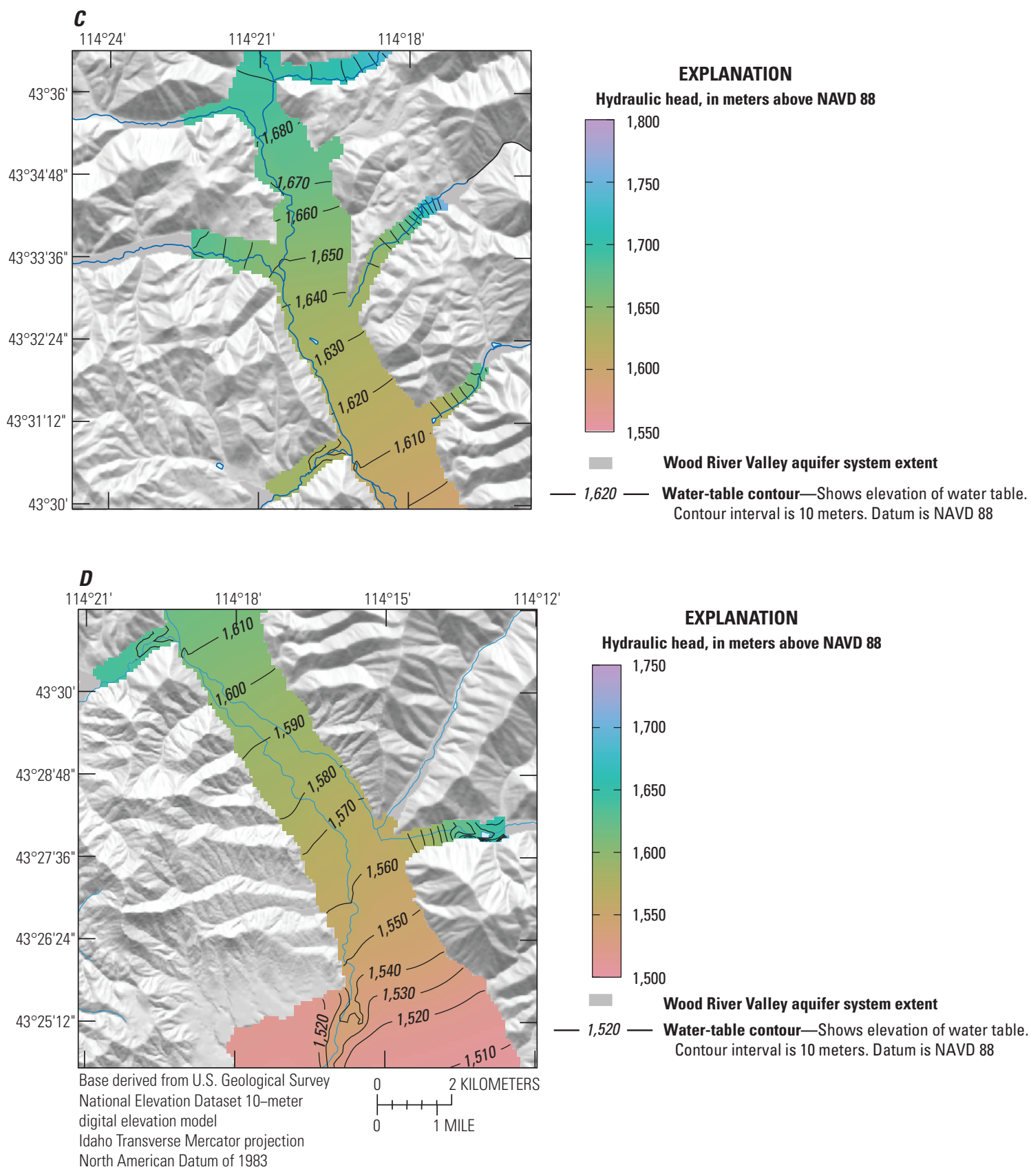

Figure 21.-Continued 


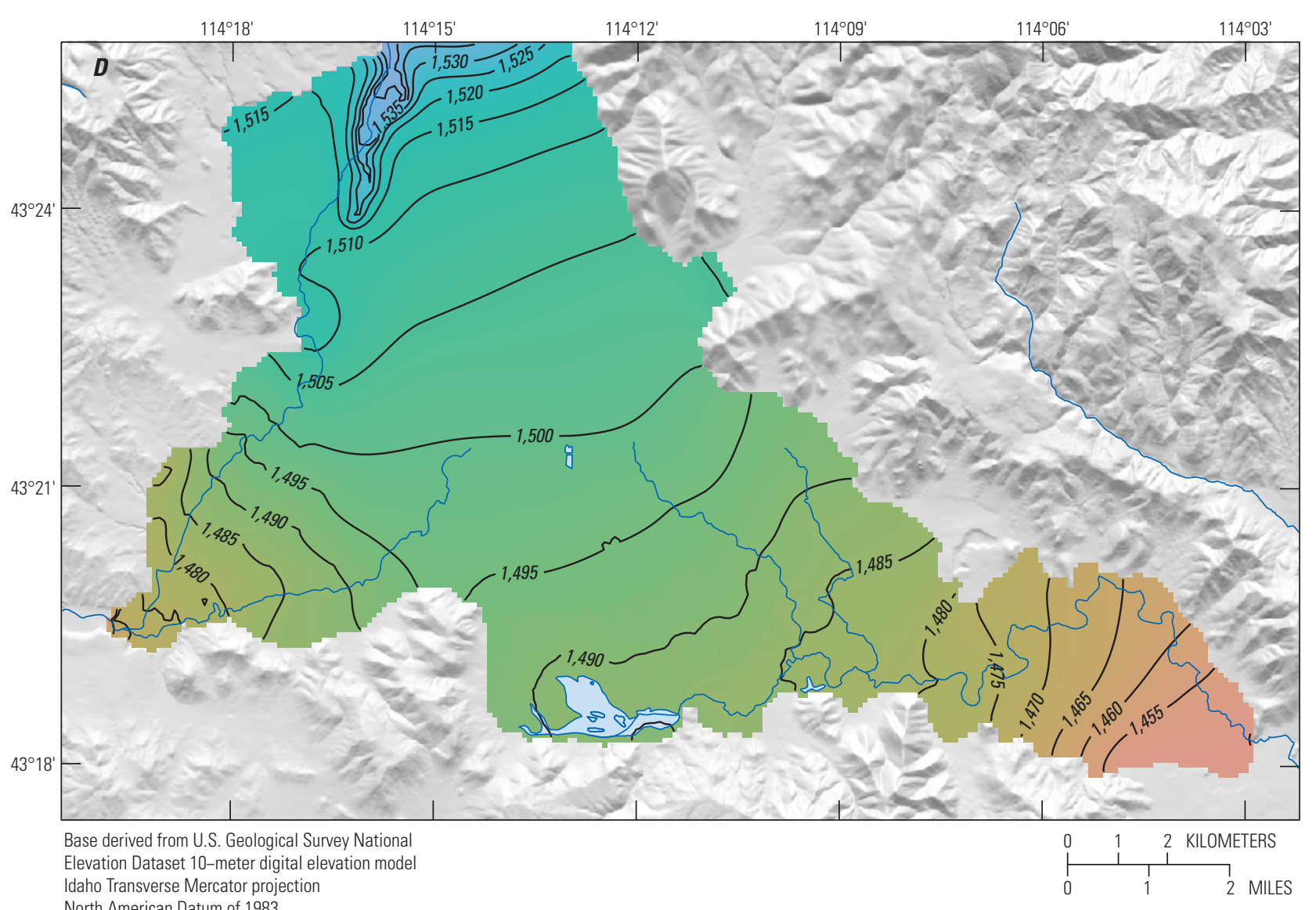

North American Datum of 1983

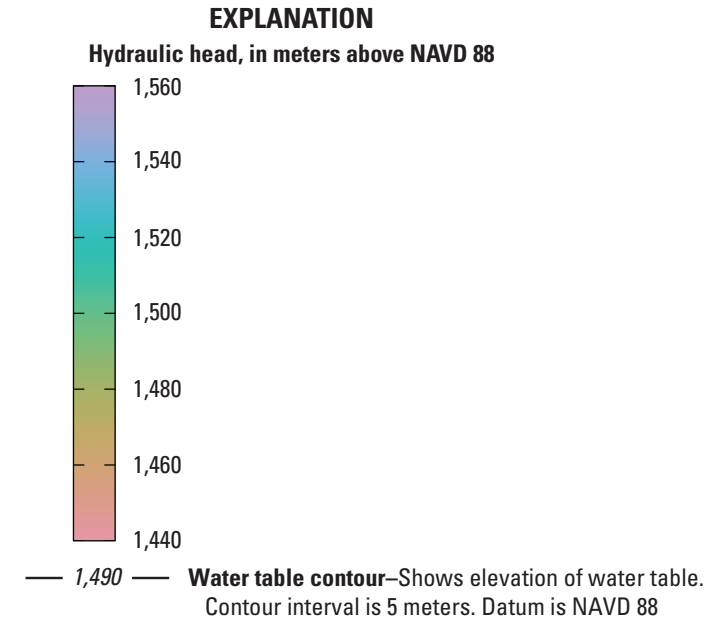

Figure 21.-Continued 
A

$\mathbf{A}^{\prime}$

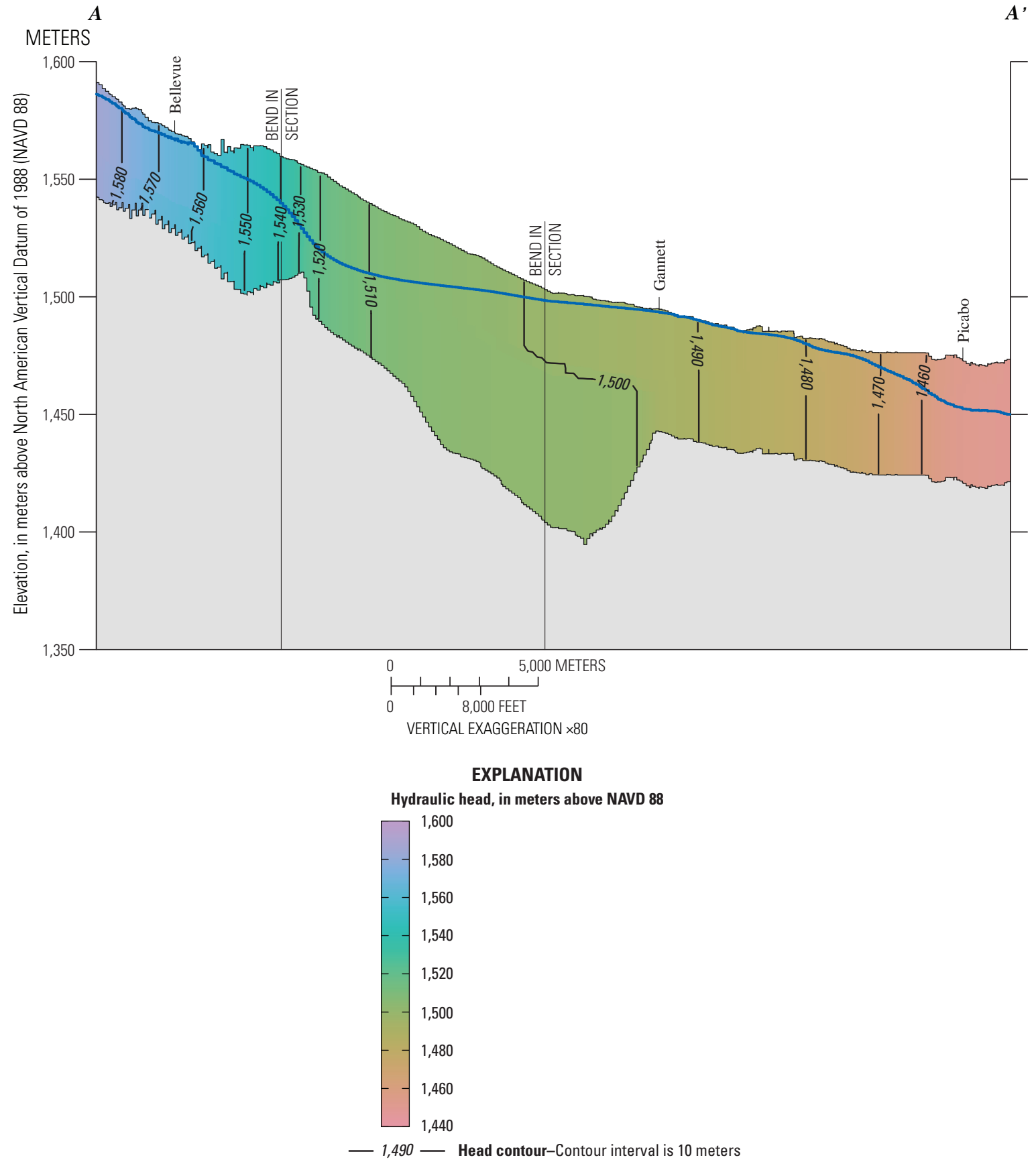

Water-table contour-Shows elevation of water table

Figure 22. Simulated hydraulic heads along transect line $A-A^{\prime}$, Wood River Valley aquifer system, south-central Idaho, December 2010. Line of cross section shown in figure 20. 


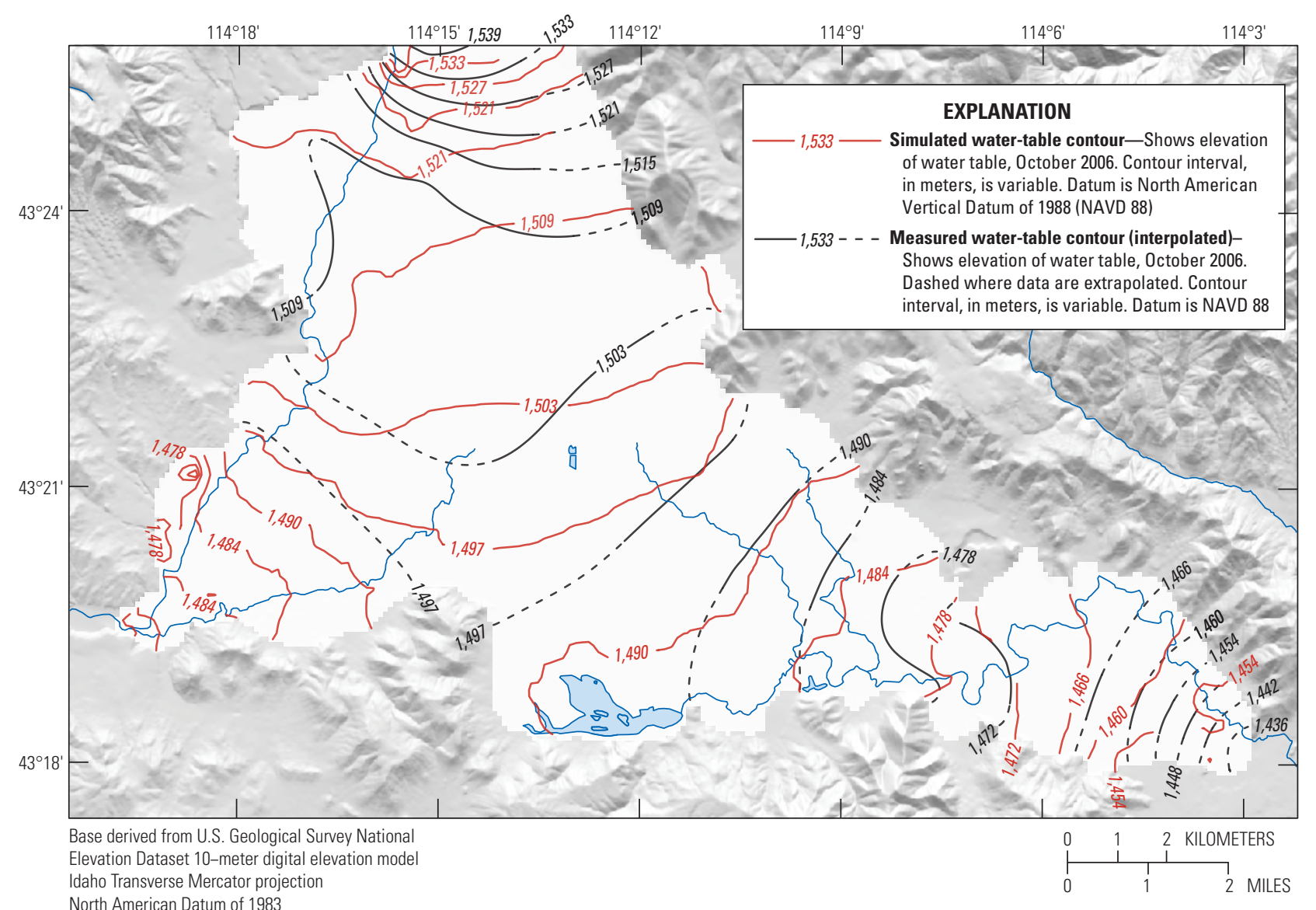

Figure 23. Simulated and measured water-table contours, southern part of the Wood River Valley, south-central Idaho, October 2006.

The USGS groundwater-monitoring network consists of 94 wells, with 387 groundwater-level measurements recorded in these wells during the duration of the transient simulation (1995-2010). The residual (or error) of the simulated groundwater level is computed as the measured minus the simulated water level. A scatterplot of the residuals and simulated hydraulic head at the USGS wells is shown in figure 24A. Positive values for the residual indicate that the simulated value was too small, and negative values indicate the simulated value was too large, whereas zero indicates an exact match with the measurement. Residual values range from -18.9 to $21.1 \mathrm{~m}$ (-62.0 to $69.3 \mathrm{ft}$ ), with a mean absolute error (MAE) and SD of $2.4 \mathrm{~m}(8.0 \mathrm{ft})$ and $3.5 \mathrm{~m}$ $(11.6 \mathrm{ft})$, respectively. The mean residual of simulated water levels for a well, averaged over the 1995 through 2010 time period, is shown spatially and proportionally in figure 25 . The residual analysis indicates an overall good fit between simulated and measured groundwater levels in the USGS groundwater-monitoring network wells.
There are 254 geolocated driller wells. For each well, a single groundwater-level measurement was recorded by the driller when the well was completed. A scatterplot of the residuals compared to simulated values at the geolocated wells is shown in figure 24B. Residual values range from -53.1 to $23.2 \mathrm{~m}$ (-174.2 to $76.0 \mathrm{ft}$ ), with a MAE and SD of $5.5 \mathrm{~m}$ $(18.0 \mathrm{ft})$ and $7.6 \mathrm{~m}(25.0 \mathrm{ft})$, respectively. The residuals are shown spatially and proportionally in figure 26 . The residual analysis indicates an adequate fit between model and measured water levels in geolocated driller wells.

There are 416 PLSS-located driller wells. A single groundwater-level measurement was recorded by the driller when each well was completed. A scatterplot of the residuals compared to the simulated values at the geolocated wells is shown in figure $24 \mathrm{C}$. Residual values range from -40.6 to $69.5 \mathrm{~m}$ (-133.2 to $228.0 \mathrm{ft}$ ), with a MAE and SD of $5.3 \mathrm{~m}$ $(17.5 \mathrm{ft})$ and $8.7 \mathrm{~m}(28.6 \mathrm{ft})$, respectively. The residuals are shown spatially and proportionally in figure 27 . The residual analysis indicates an adequate fit between simulated and measured water levels in PLSS-located driller wells. 


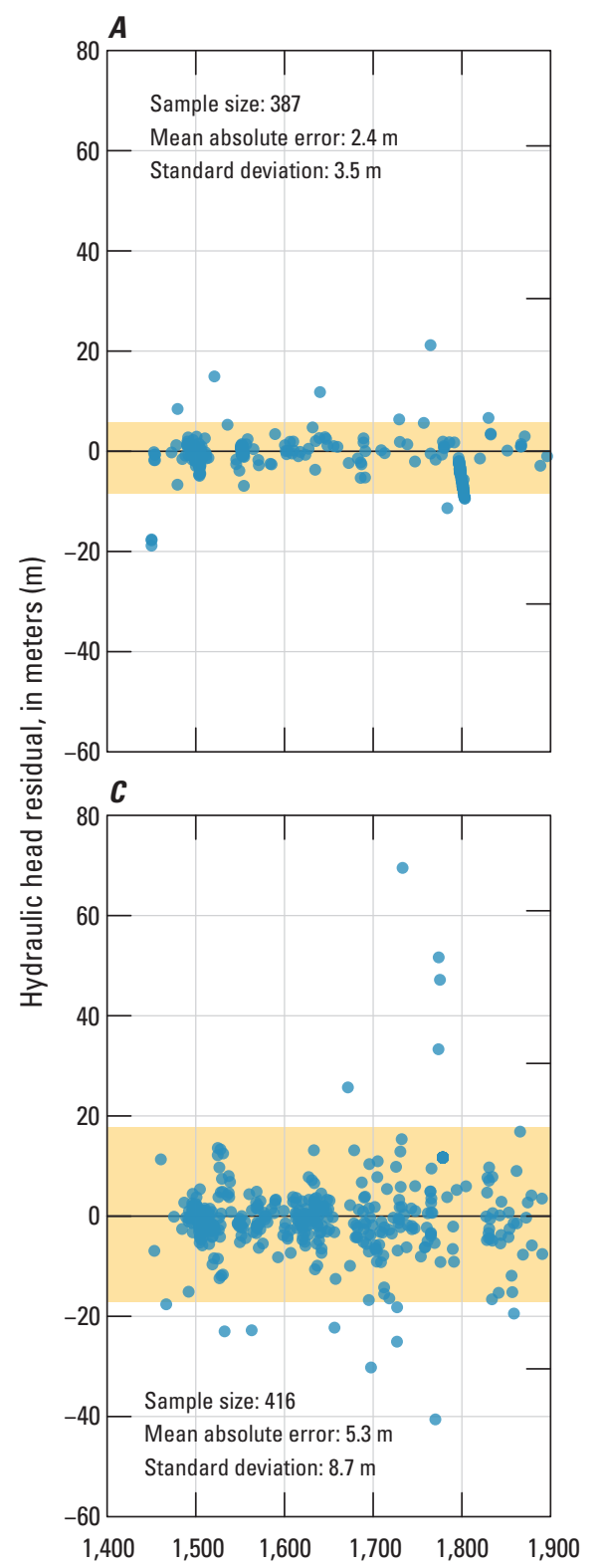

B

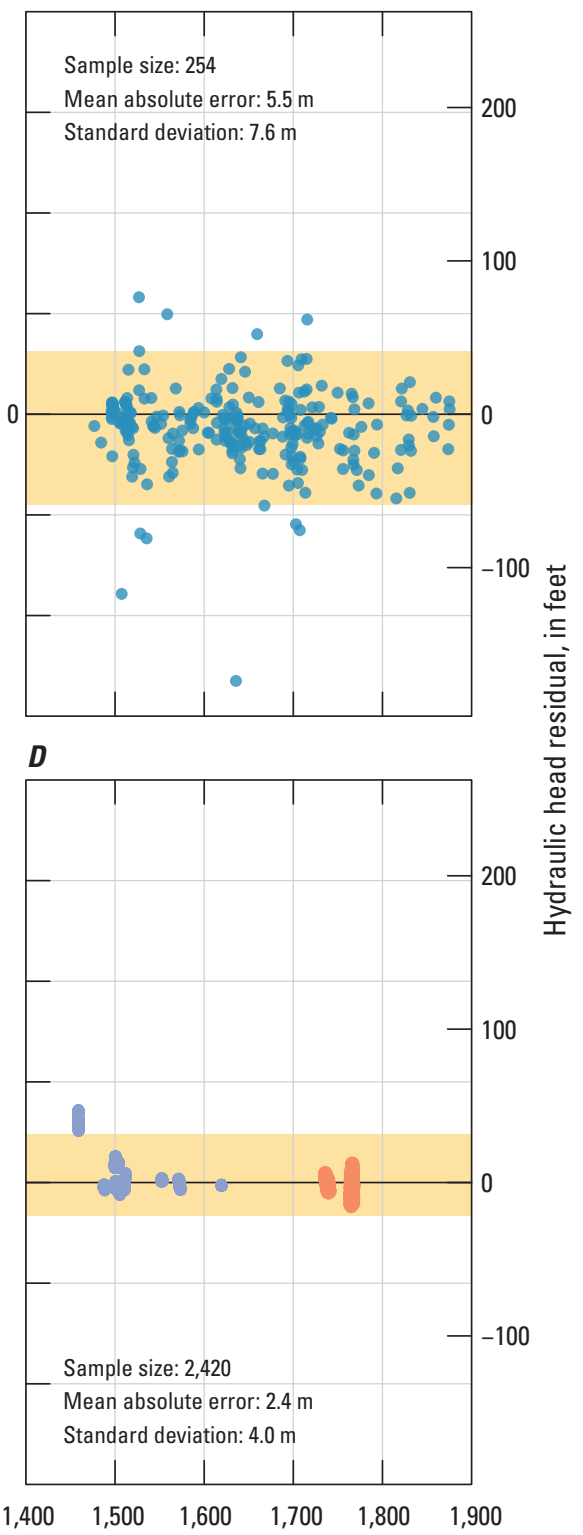

Simulated hydraulic head, in meters above North American Vertical Datum of 1988

EXPLANATION

$\begin{array}{ll} & \text { 95-percent confidence interval } \\ -\quad \text { Residual versus simulated } \\ \text { Sun Valley Water and Sewer District (SVWSD) well } \\ \text { The Nature Conservancy (TNC) well }\end{array}$

Figure 24. Water-table residuals in (A) U.S. Geological Survey groundwatermonitoring network wells, $(B)$ Geolocated driller wells, $(C)$ Public Land Survey System-located driller wells, and $(D)$ two of the Sun Valley Water and Sewer District production wells and The Nature Conservancy groundwater-monitoring network wells, Wood River Valley aquifer system, south-central Idaho, 1995-2010. 


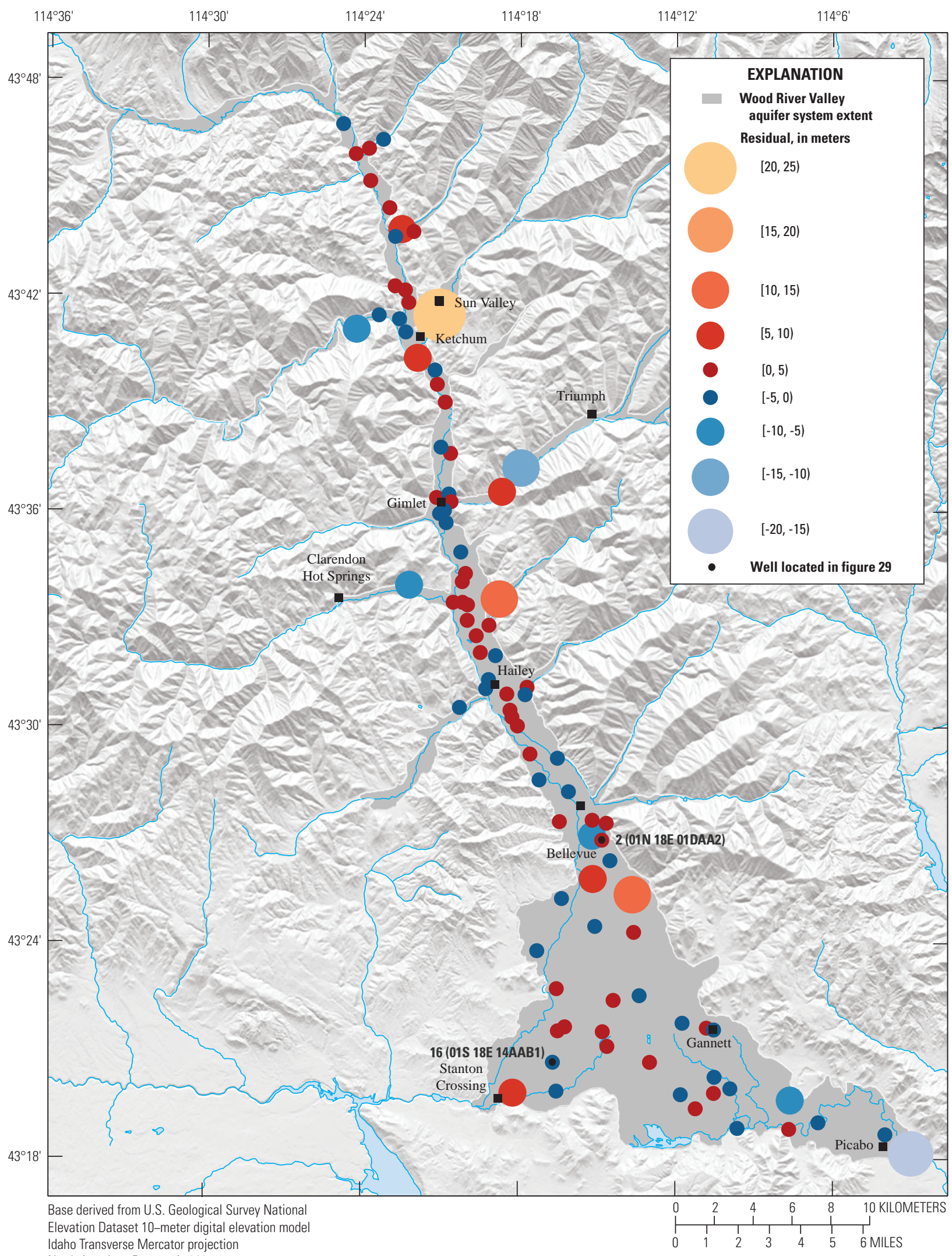

North American Datum of 1983

Figure 25. Spatial distribution of average hydraulic head differences between measured and simulated values (residuals) in U.S. Geological Survey groundwater-monitoring network wells, Wood River Valley aquifer system, south-central Idaho, 1995-2010. 


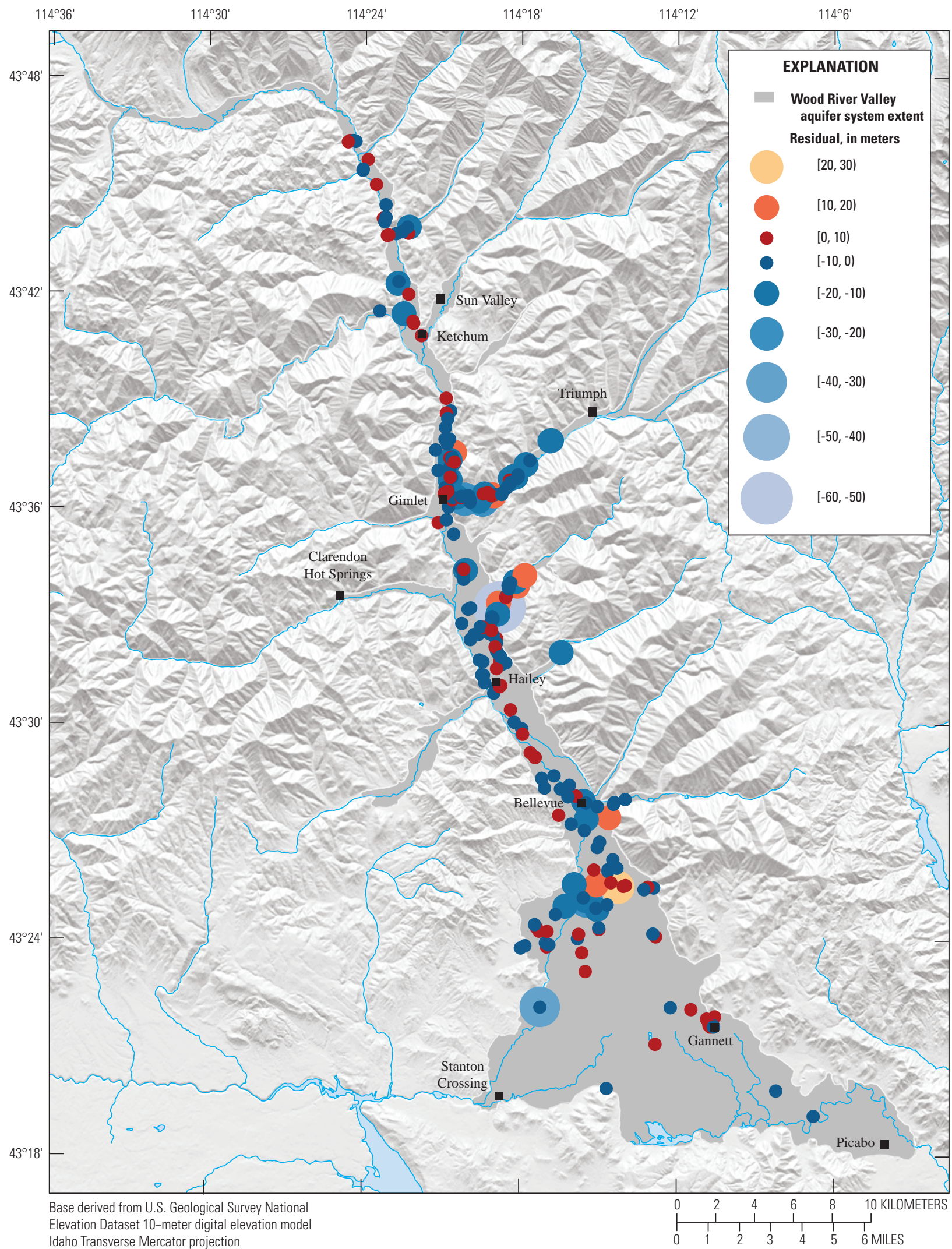

daho Transverse Mercator projection

Figure 26. Spatial distribution of average hydraulic head differences between measured and simulated values (residuals) in the geolocated driller wells, Wood River Valley aquifer system, south-central Idaho, 1995-2010. 


\section{Calibrated Groundwater Flow Model}

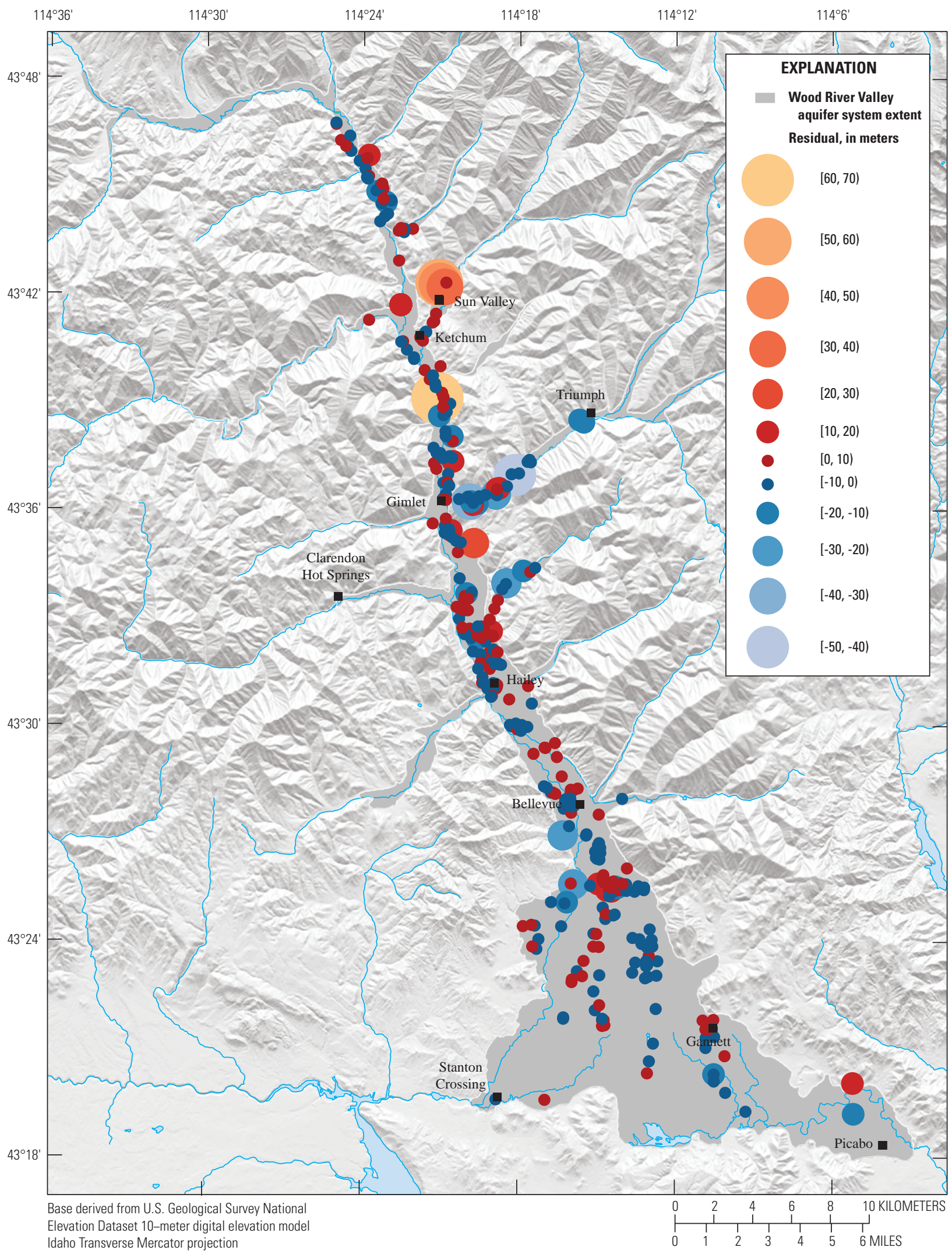

North American Datum of 1983

Figure 27. Spatial distribution of average hydraulic head differences between simulated and measured values (residuals) in the Public Land Survey System-located driller wells, Wood River Valley aquifer system, south-central Idaho, 1995-2010. 
Intermittent groundwater-level measurements were recorded in two of the SVWSD production wells, with 393 groundwater levels recorded in these wells during the 1995 through 2010 time period. A scatterplot of the residuals compared to simulated values at the SVWSD production wells is shown in figure 24D. Residual values range from -4.7 to $3.7 \mathrm{~m}$ (-15.3 to $12.2 \mathrm{ft})$, with a MAE and SD of $1.1 \mathrm{~m}$ $(3.7 \mathrm{ft})$ and $1.3 \mathrm{~m}(4.4 \mathrm{ft})$, respectively. The mean residual of simulated water levels for a well, averaged during 1995-2010, is shown spatially and proportionally in figure 28 . The residual analysis indicates a good fit between simulated and measured water levels in SVWSD production wells.

TNC groundwater-monitoring network consists of 10 wells, with 2,027 groundwater-level measurements recorded in these wells during the 1995 through 2010 time period. The period-of-record for groundwater-level measurements is relatively short in duration, spanning the last 9 months of the 16-year simulation. Groundwater-level measurements recorded at 15-minute intervals were averaged to get mean daily values. A scatterplot of the residuals compared to the simulated values at the TNC wells is shown in figure 24D. Residual values ranged from -2.5 to $14.4 \mathrm{~m}$ (-8.2 to $47.2 \mathrm{ft})$, with a MAE and SD of $2.7 \mathrm{~m}(8.8 \mathrm{ft})$ and $4.3 \mathrm{~m}$ (14.0 ft), respectively. The mean residual of simulated groundwater levels for a well, averaged over the 1995 through 2010 time period, is shown spatially and proportionally in figure 28. The residual analysis indicates an overall good fit between simulated and measured water levels in TNC wells.

Comparisons between simulated and measured groundwater levels over time are made for selected wells in the WRV (well locations shown in figs. 25 and 28). The wells selected for comparison provide a representative sample of the transient groundwater-level measurements in each of the relevant well groups, as well as adequate spatial coverage in the model domain. Selected wells were completed in the unconfined alluvial aquifer-with the exception of USGS well 16 (01S 18E 14AAB1), which was completed in the confined alluvial aquifer. Measured and simulated groundwater levels are presented in the groundwater-level hydrographs shown in figures 29 (selected USGS wells), 30 (selected SVWSD wells), and 31 (selected TNC wells). No attempt was made to match the measured groundwater levels during the transient model warm-up period (1995-1997).

The measured and simulated groundwater-level hydrographs for USGS well 16 (01S 18E 14AAB1) are shown in figure 29A. The model tends to overpredict the magnitude of the seasonal fluctuations and simulates a more rapid recovery during the dry conditions present in autumn 2007, a particularly dry year. This is a flowing well that must be shut in prior to collecting a measurement, and the well occasionally may not have been shut in long enough prior to collecting the measurement.
The measured and simulated groundwater-level hydrographs for USGS well 2 (01N 18E 01DAA2) are shown in figure 29B. The model-to-measurement fit is good in this well, matching both the amplitude and seasonal fluctuations.

The measured and simulated groundwater-level hydrographs for SVWSD well 765 (04N 18E 07ADD; also known as Sun Valley Well 2) are shown in figure 30A. The model matches the timing of the observed seasonal variations, but simulates smaller amplitude variations. Given that the well is located in the Trail Creek Valley, this underprediction of the model may have resulted from the non-explicit representation of Trail Creek in the model. An explicit representation of Trail Creek in the model domain likely would result in a groundwater-level response to stream-stage changes in Trail Creek. Some of the large-amplitude fluctuations in the observed water-level hydrograph are thought to be driven by groundwater pumping in the City of Sun Valley well field. This pumping is represented in the model as an average monthly pumping rate. In reality, the various city wells cycle on and off to match the observed demand. These rapid changes in pumping are not represented in the model.

The measured and simulated groundwater-level hydrographs for SVWSD well 766 (04N 18E 19DCD1; also known as, Sun Valley Well 11) are shown in figure 30B. The model-to-measurement fit generally is adequate in this well, matching both the timing and seasonal amplitude much better than well 765 (04N 18E 07ADD; fig. 30A). This improved match between measured and simulated water levels most likely is owing to the explicit representation in the model of seasonal stream-stage changes in the Big Wood River.

The measured and simulated water-level hydrographs are shown for TNC well 770 (02N 18E 09BCD1) in figure 31A, and for TNC well $776(02 \mathrm{~N} 18 \mathrm{E} 35 \mathrm{ACC} 1)$ in figure $31 \mathrm{~B}$. The model-to-measurement fit generally was adequate in these wells over their relatively short period of record.

The inclusion of the SVWSD and TNC groundwaterlevel measurements in the model-calibration process provided valuable information pertaining to the seasonal fluctuations in the water table at locations where, in most cases, field data were limited. For example, figure 31 shows that the measured seasonal groundwater-level fluctuations for 2010 near Hailey (fig. 31A) likely were minimal, but near Bellevue

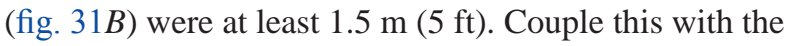
SVWSD groundwater-level measurements indicating that there was about a $1.5-\mathrm{m}(5-\mathrm{ft})$ seasonal fluctuation north of Gimlet (fig. 28). These observations of seasonal water-table variability helped constrain model calibration. 


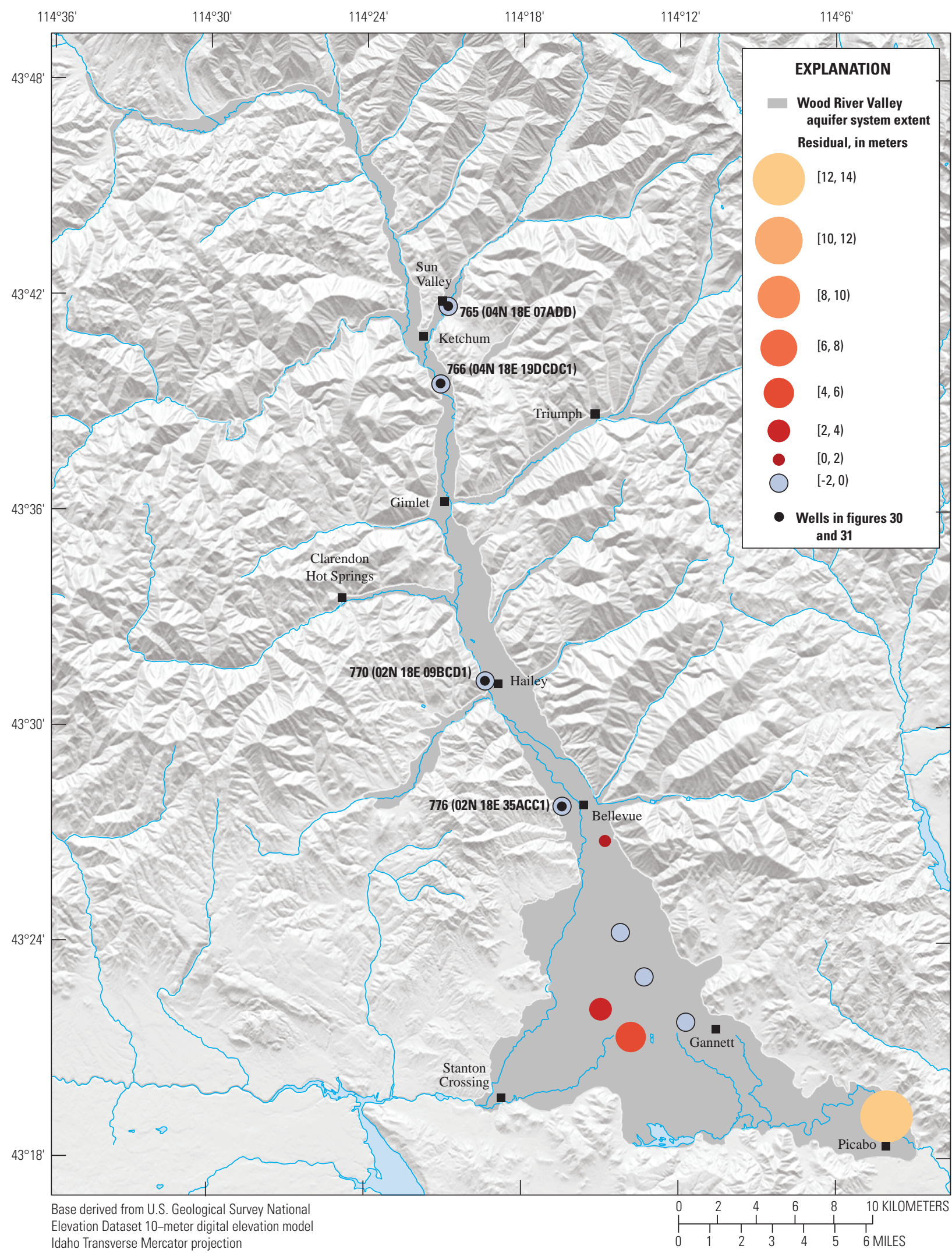

North American Datum of 1983

Figure 28. Spatial distribution of average hydraulic head differences between measured and simulated values (residuals) in two production wells (the two most northern well sites on the map) of the Sun Valley Water and Sewer District and wells in The Nature Conservancy groundwater-monitoring network, Wood River Valley aquifer system, south-central Idaho, 1995-2010. 


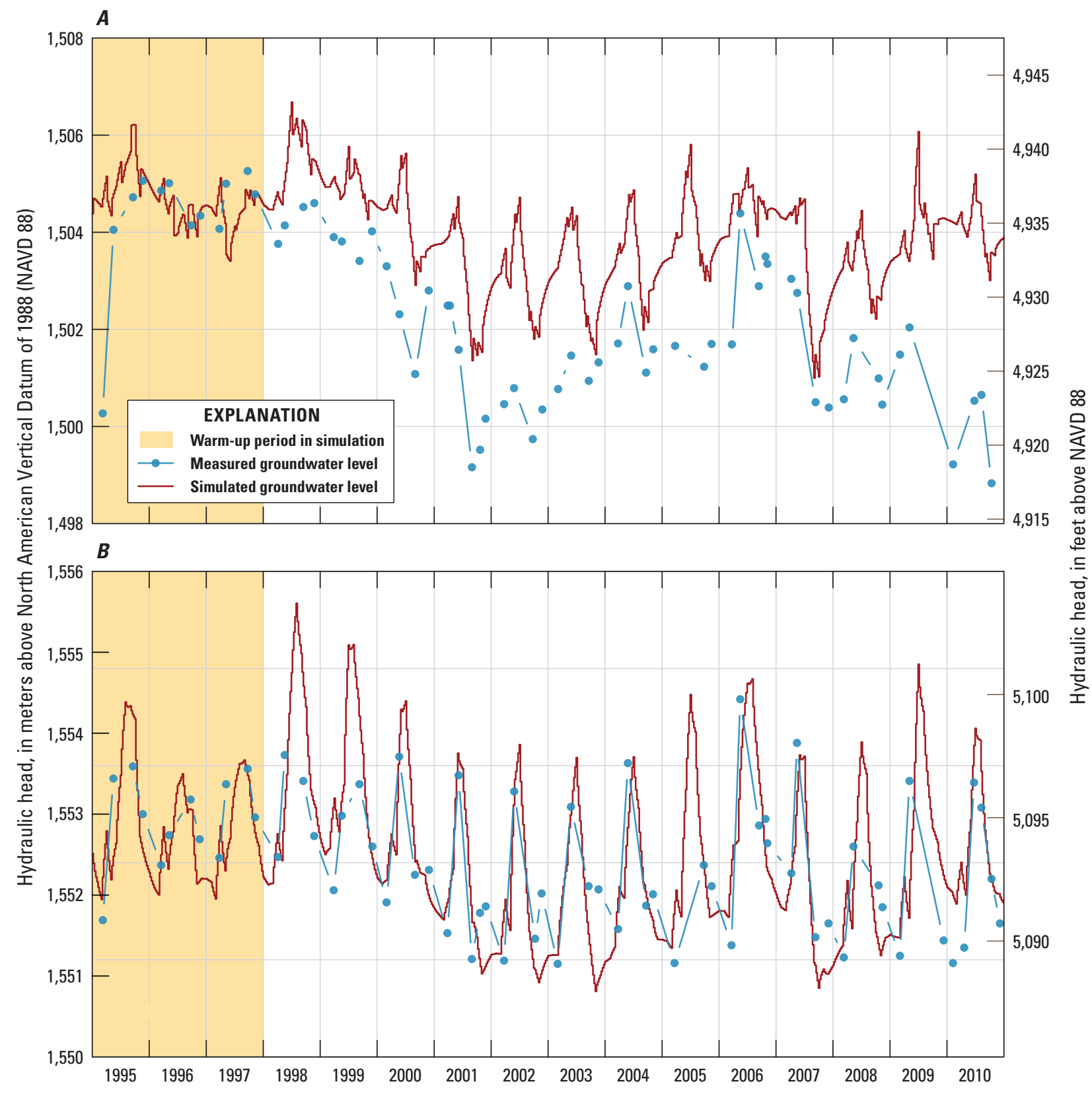

Figure 29. Measured and simulated groundwater-level hydrographs for U.S. Geological Survey wells $(A)$ 01S 18E 14AAB1, and (B) 01N 18E 01DAA2, Wood River Valley aquifer system, south-central Idaho, 1995-2010. 


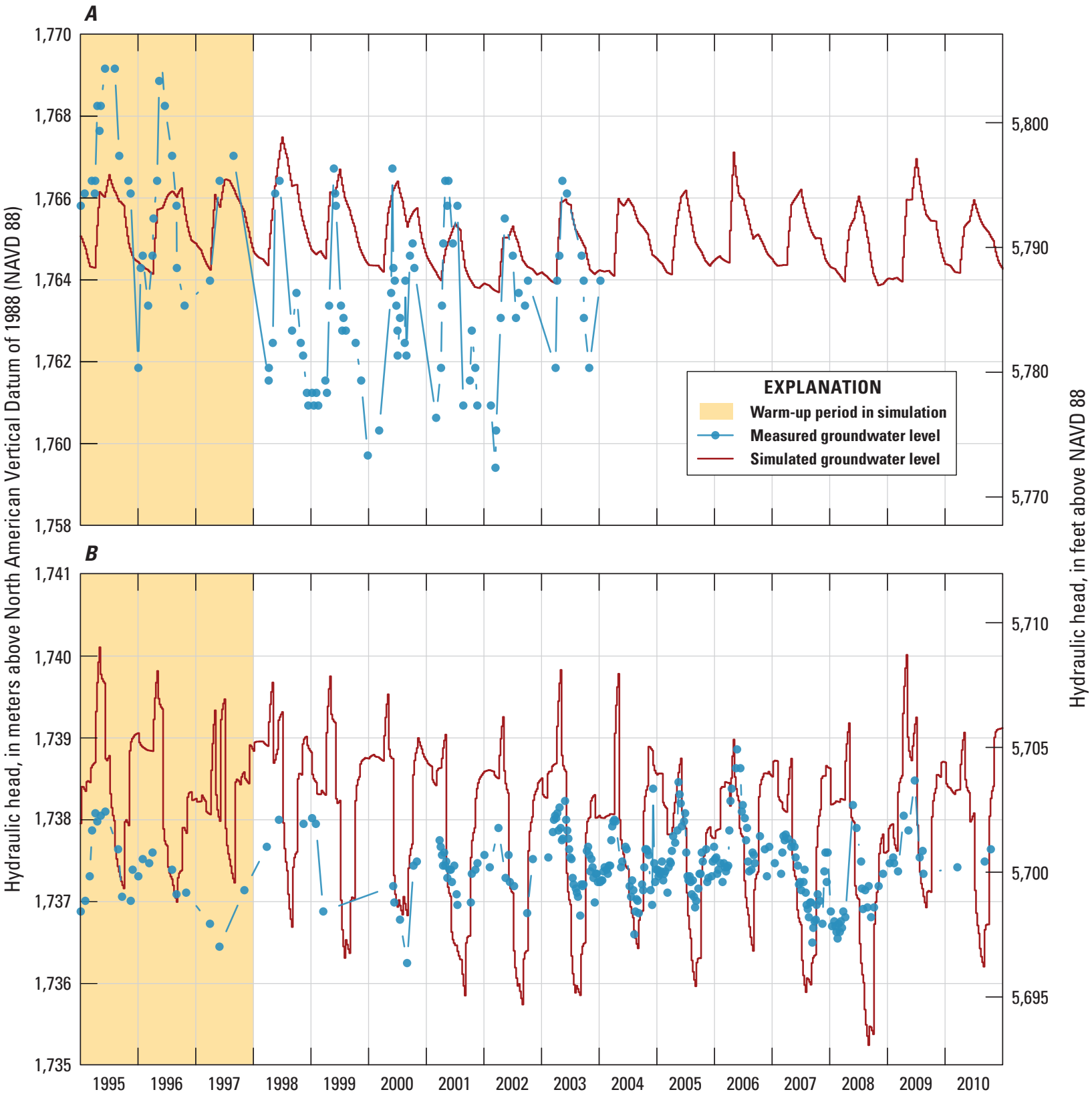

Figure 30. Measured and simulated groundwater-level hydrographs for Sun Valley Water and Sewer District wells $(A)$ O4N 18E 07ADD, and (B) 04N 18E 19DCDC1, Wood River Valley aquifer system, southcentral Idaho, 1995-2010. 


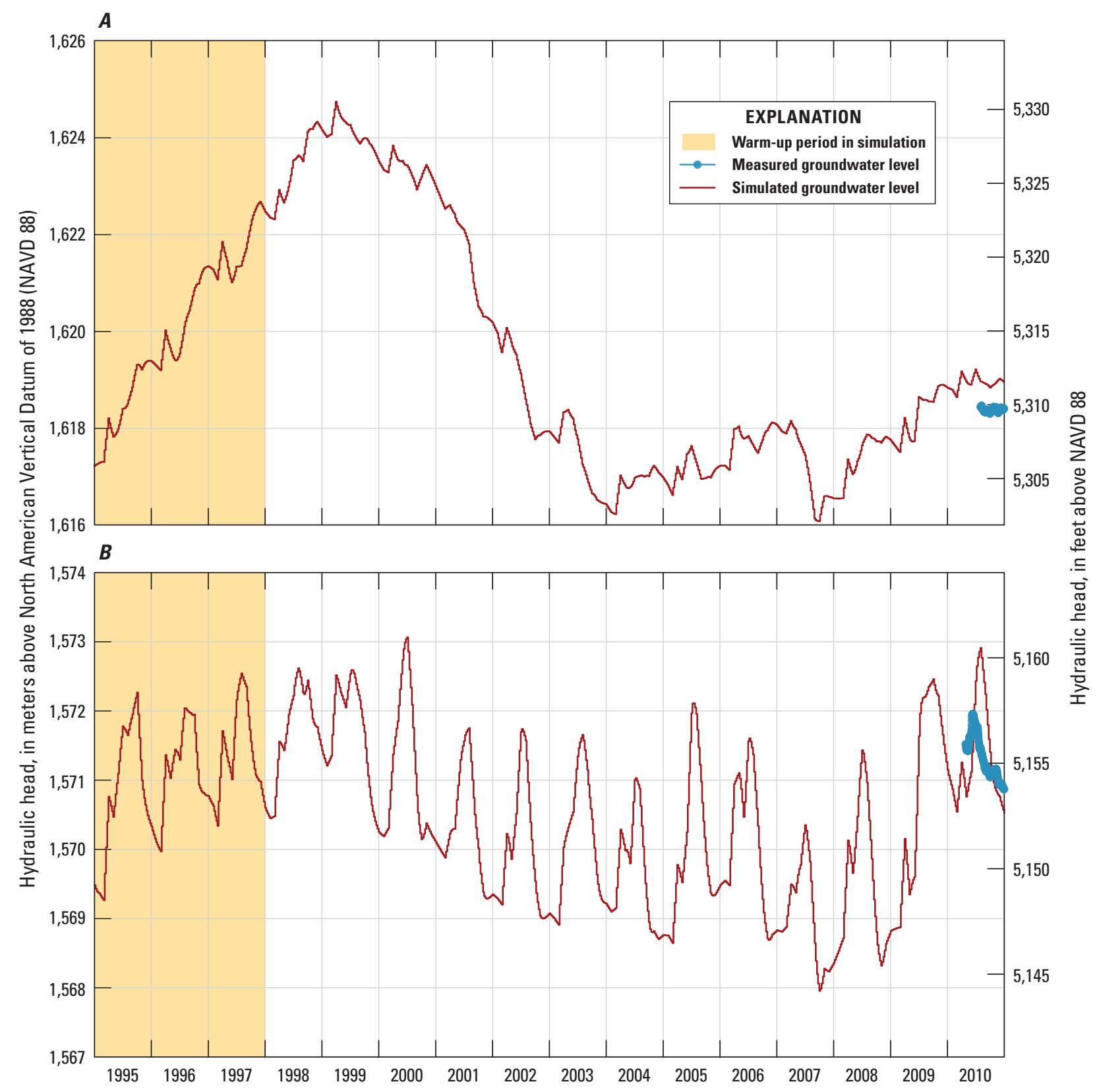

Figure 31. Measured and simulated groundwater-level hydrographs for The Nature Conservancy wells (A) 02N 18E 09BCD1, and (B) 02N 18E 35ACC1, Wood River Valley, south-central Idaho, 1995-2010. 


\section{Sensitivity Analysis}

Composite sensitivity values were generated by the PEST code during its final optimization iteration. The composite sensitivity is a measure of how well parameters (such as riverbed conductance) can be estimated from the available information content of the calibration dataset (such as field observations of stream-aquifer flow exchange). To compare sensitivities among different model parameters, the composite sensitivities were multiplied by their corresponding absolute calibrated parameter value to give the "relative composite sensitivity" of each parameter adjusted during model calibration (table 8, fig. 32). For parameters that were logarithmically transformed during model calibration (such as the horizontal hydraulic conductivity, storage coefficient, riverbed conductance, and drain conductance), the relative composite sensitivities were determined by multiplying a parameters composite sensitivity by the absolute logarithm of its calibrated parameter value. The relative composite sensitivity is a measure of the composite changes in the model outputs that are incurred by a fractional change in the parameter value (Doherty, 2005, p. 5-17).
The relative composite sensitivity values indicate that observations inform hydraulic conductivity and tributary underflow control parameters better than the storage coefficient, riverbed conductance, drain conductance, and irrigation efficiency. A detailed description of observations and parameters included in the model-calibration process is available in appendix $\mathrm{H}$. The parameter most sensitive to observations is the hydraulic conductivity, a measure of the ease with which water can move through pore spaces or fractures. The large sensitivity of this parameter indicates a relatively robust observational dataset associated with hydraulic conductivity; that is, water-level observations recorded at wells located throughout the model domain and during the calibration period (1995-2010). In comparison, the observations that inform the relatively insensitive parameter estimates (such as drain conductance) are sparsely distributed (both spatially and temporally). For example, observations that help to inform estimates of aquifer storage properties (such as multiple head measurements recorded in the same well throughout the calibration period) are limited within the study area. Therefore, the storage coefficient estimates primarily were informed by water-level observations in just a few wells where time-series data were available, thus indicating a large degree of uncertainty for these estimates.

Table 8. Estimates and relative composite sensitivities of parameters varied during the calibration process for the Wood River Valley groundwater-flow model, south-central Idaho.

[Site No.: Unique identifier for estimated parameters within a parameter type. That is the pilot-point identifier (point No.) for horizontal hydraulic conductivity and storage coefficient; river subreach identifier (subreach No.) for riverbed conductance; groundwater-outlet boundary (1 is 'Stanton Crossing' and 2 is 'Silver Creek') for drain conductance; irrigation-entity identifier (entity No.) for irrigation efficiency; and tributary-valley identifier (tributary No.) for tributary underflow scalar. Lover and Upper bounds: Define the range of values a parameter can assume during the model-calibration process. Starting value: Initial parameter estimate prior to model calibration. Calibrated value: Estimated by parameter-estimation program (PEST). Entry in bold indicates that the calibrated parameter value is at a bound or starting value. Relative composite sensitivity: Statistic generated during the final iteration of PEST. Rank: Relative composite sensitivity, in descending order. Abbreviations: m/d, meter per day; $\mathrm{m}^{2} / \mathrm{d}$, square meter per day; d, days; -, no site No.]

\begin{tabular}{|c|c|c|c|c|c|c|c|}
\hline Parameter type & $\begin{array}{l}\text { Site } \\
\text { No. }\end{array}$ & $\begin{array}{l}\text { Lower } \\
\text { bound }\end{array}$ & $\begin{array}{l}\text { Upper } \\
\text { bound }\end{array}$ & $\begin{array}{l}\text { Starting } \\
\text { value }\end{array}$ & $\begin{array}{l}\text { Calibrated } \\
\text { value }\end{array}$ & $\begin{array}{c}\text { Relative } \\
\text { composite } \\
\text { sensitivity }\end{array}$ & Rank \\
\hline \multirow{12}{*}{ Horizontal hydraulic conductivity $(\mathrm{m} / \mathrm{d})$} & 2 & $1.0 \times 10^{-10}$ & $1.0 \times 10^{10}$ & $2.1 \times 10^{1}$ & $1.0 \times 10^{2}$ & $2.6 \times 10^{-2}$ & 58 \\
\hline & 3 & $1.0 \times 10^{-10}$ & $1.0 \times 10^{10}$ & $2.1 \times 10^{1}$ & $2.2 \times 10^{2}$ & $1.2 \times 10^{-2}$ & 103 \\
\hline & 4 & $1.0 \times 10^{-10}$ & $1.0 \times 10^{10}$ & $2.1 \times 10^{1}$ & $2.5 \times 10^{2}$ & $1.3 \times 10^{-2}$ & 96 \\
\hline & 7 & $1.0 \times 10^{-10}$ & $1.0 \times 10^{10}$ & $2.1 \times 10^{1}$ & $8.9 \times 10^{-1}$ & $3.0 \times 10^{-4}$ & 245 \\
\hline & 8 & $1.0 \times 10^{-10}$ & $1.0 \times 10^{10}$ & $2.1 \times 10^{1}$ & $2.8 \times 10^{1}$ & $1.1 \times 10^{-2}$ & 106 \\
\hline & 9 & $1.0 \times 10^{-10}$ & $1.0 \times 10^{10}$ & $2.1 \times 10^{1}$ & $2.9 \times 10^{1}$ & $6.9 \times 10^{-2}$ & 17 \\
\hline & 10 & $1.0 \times 10^{-10}$ & $1.0 \times 10^{10}$ & $2.1 \times 10^{1}$ & $1.6 \times 10^{2}$ & $8.0 \times 10^{-2}$ & 10 \\
\hline & 11 & $1.0 \times 10^{-10}$ & $1.0 \times 10^{10}$ & $2.1 \times 10^{1}$ & $7.2 \times 10^{2}$ & $2.6 \times 10^{-2}$ & 59 \\
\hline & 16 & $1.0 \times 10^{-10}$ & $1.0 \times 10^{10}$ & $2.1 \times 10^{1}$ & $4.7 \times 10^{1}$ & $2.2 \times 10^{-2}$ & 69 \\
\hline & 17 & $1.0 \times 10^{-10}$ & $1.0 \times 10^{10}$ & $2.1 \times 10^{1}$ & $3.8 \times 10^{2}$ & $3.5 \times 10^{-2}$ & 44 \\
\hline & 18 & $1.0 \times 10^{-10}$ & $1.0 \times 10^{10}$ & $2.1 \times 10^{1}$ & $3.7 \times 10^{4}$ & $1.4 \times 10^{-2}$ & 90 \\
\hline & 19 & $1.0 \times 10^{-10}$ & $1.0 \times 10^{10}$ & $2.1 \times 10^{1}$ & $3.3 \times 10^{2}$ & $2.7 \times 10^{-2}$ & 55 \\
\hline
\end{tabular}


Table 8. Estimates and relative composite sensitivities of parameters varied during the calibration process for the Wood River Valley groundwater-flow model, south-central Idaho.-Continued

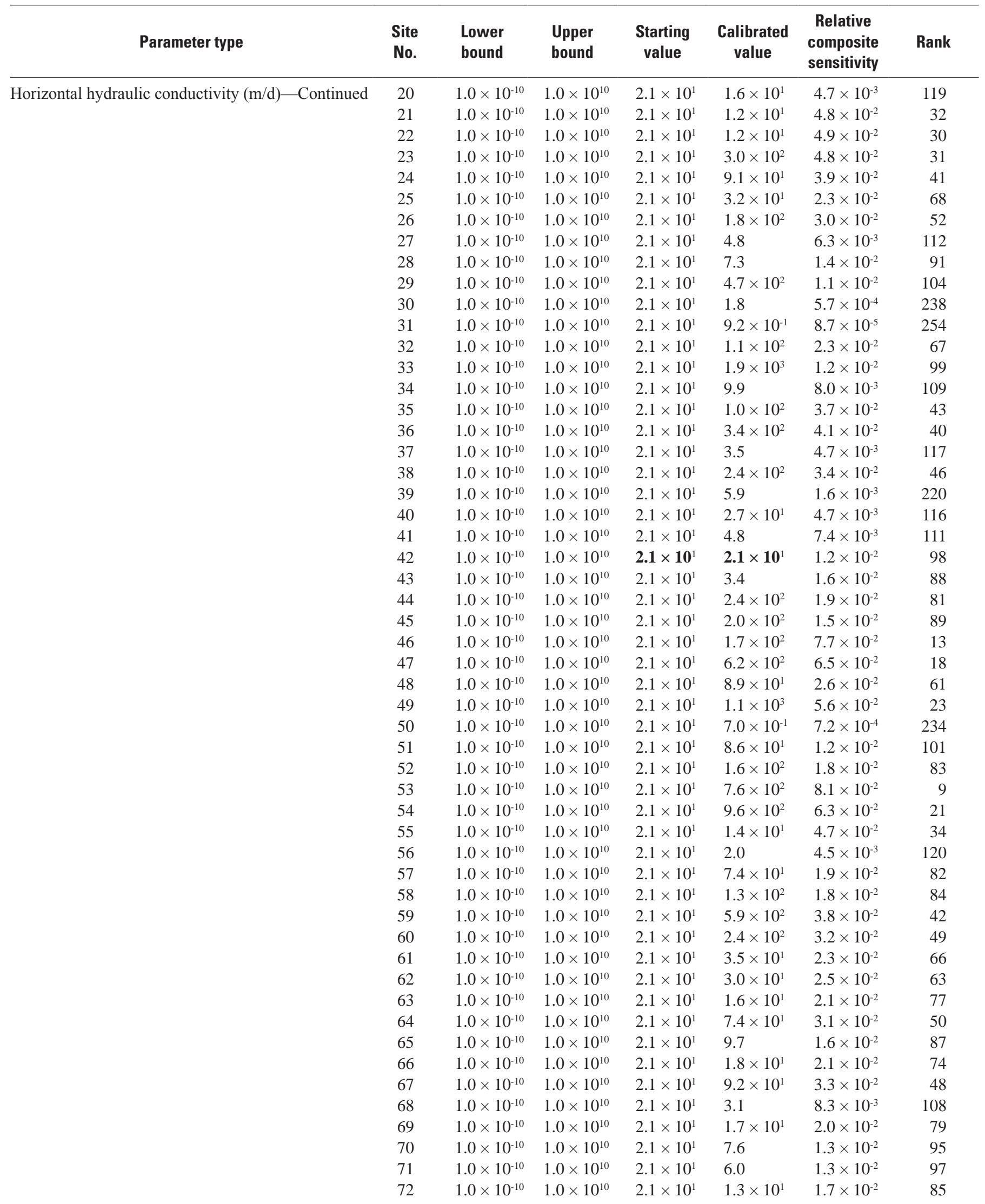


Table 8. Estimates and relative composite sensitivities of parameters varied during the calibration process for the Wood River Valley groundwater-flow model, south-central Idaho.—Continued

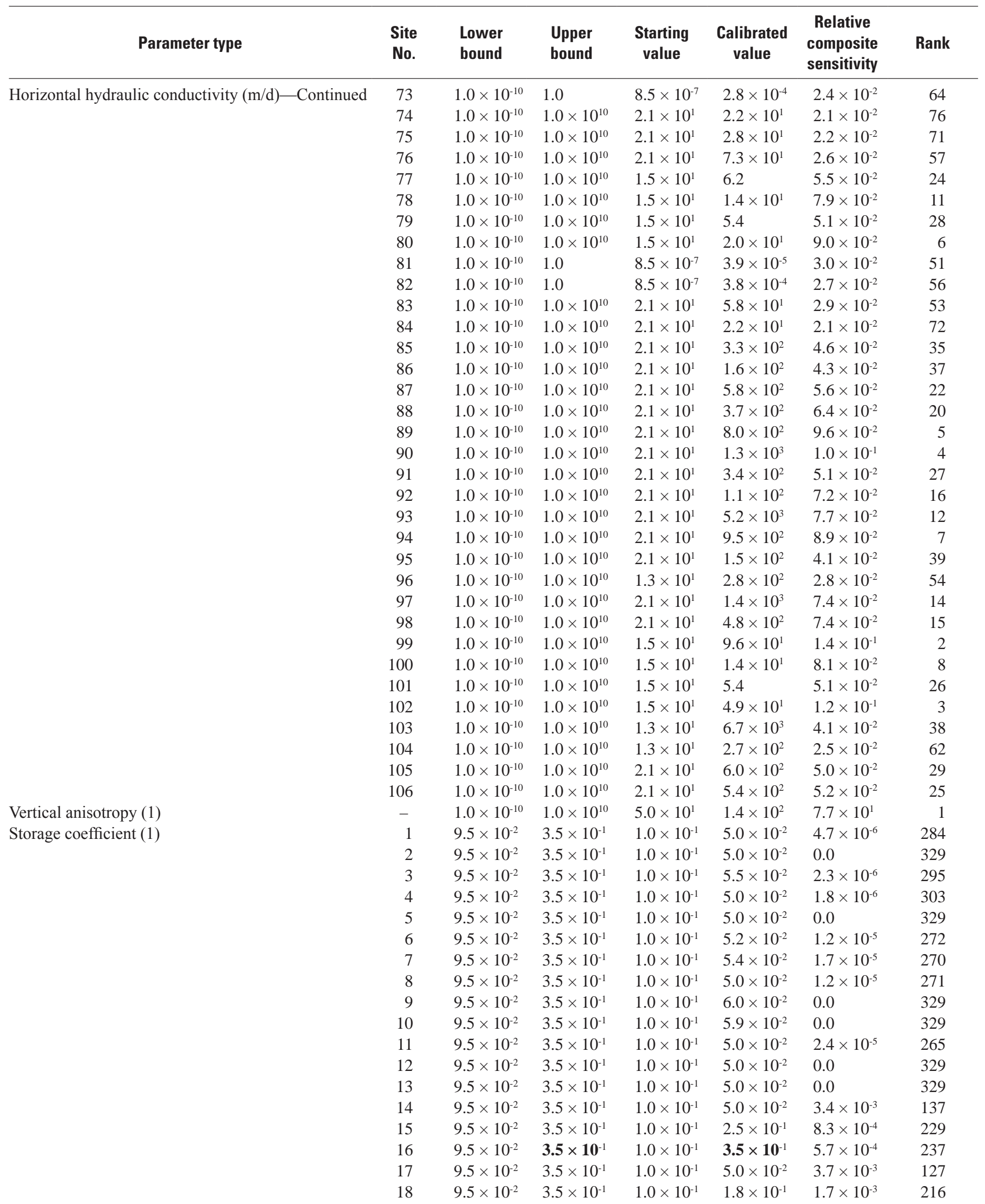


Table 8. Estimates and relative composite sensitivities of parameters varied during the calibration process for the Wood River Valley groundwater-flow model, south-central Idaho.-Continued

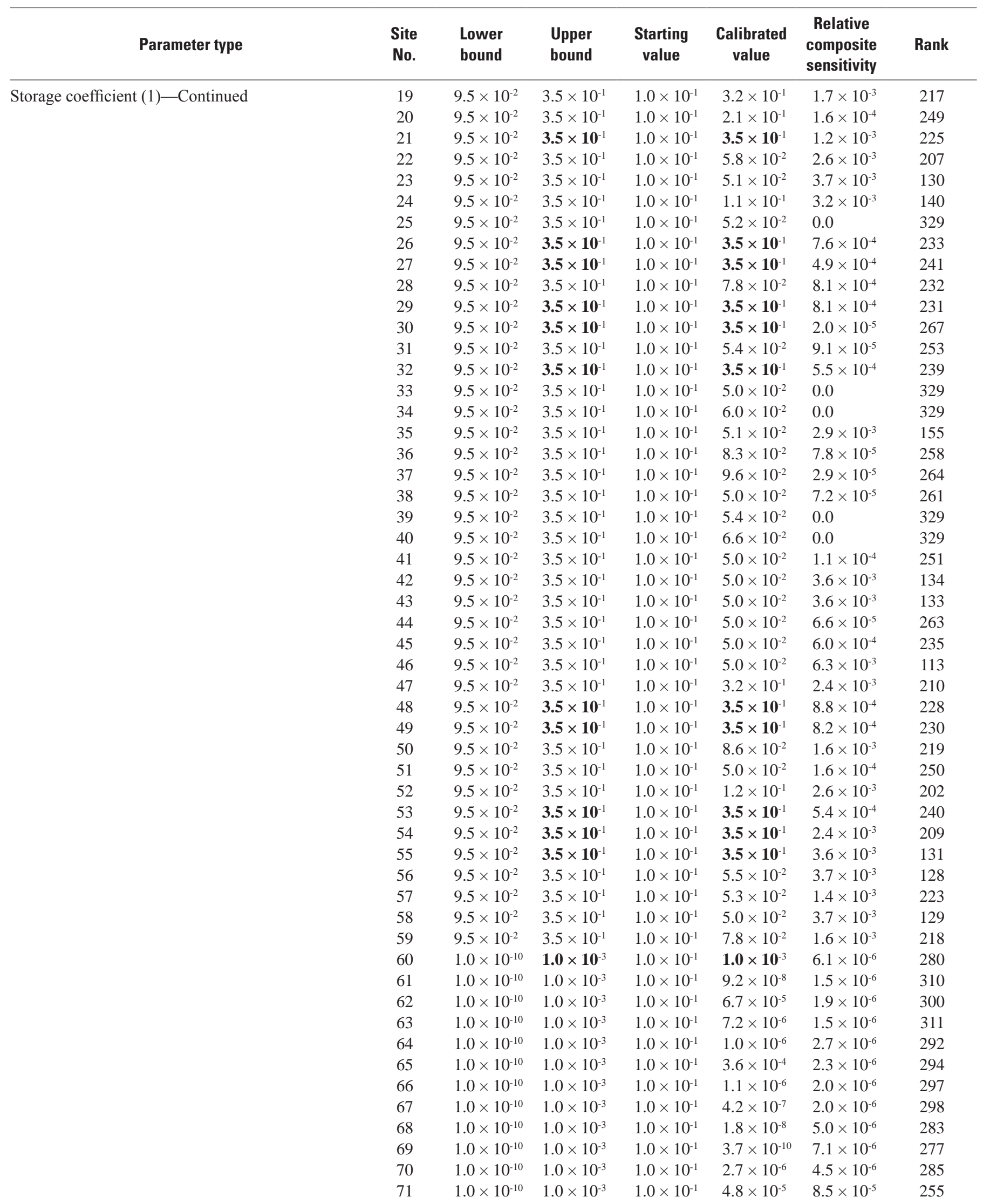


Table 8. Estimates and relative composite sensitivities of parameters varied during the calibration process for the Wood River Valley groundwater-flow model, south-central Idaho.—Continued

\begin{tabular}{|c|c|c|c|c|c|c|c|}
\hline Parameter type & $\begin{array}{l}\text { Site } \\
\text { No. }\end{array}$ & $\begin{array}{l}\text { Lower } \\
\text { bound }\end{array}$ & $\begin{array}{l}\text { Upper } \\
\text { bound }\end{array}$ & $\begin{array}{c}\text { Starting } \\
\text { value }\end{array}$ & $\begin{array}{l}\text { Calibrated } \\
\text { value }\end{array}$ & $\begin{array}{c}\text { Relative } \\
\text { composite } \\
\text { sensitivity }\end{array}$ & Rank \\
\hline \multirow{21}{*}{ Storage coefficient (1)—Continued } & 73 & $1.0 \times 10^{-10}$ & $1.0 \times 10^{-3}$ & $1.1 \times 10^{-2}$ & $7.6 \times 10^{-6}$ & $8.2 \times 10^{-5}$ & 256 \\
\hline & 74 & $1.0 \times 10^{-10}$ & $1.0 \times 10^{-3}$ & $1.0 \times 10^{-1}$ & $6.2 \times 10^{-6}$ & $6.7 \times 10^{-6}$ & 279 \\
\hline & 75 & $1.0 \times 10^{-10}$ & $1.0 \times 10^{-3}$ & $1.0 \times 10^{-1}$ & $1.5 \times 10^{-7}$ & $5.7 \times 10^{-6}$ & 281 \\
\hline & 78 & $1.0 \times 10^{-10}$ & $1.0 \times 10^{-3}$ & $3.6 \times 10^{-5}$ & $3.4 \times 10^{-6}$ & $1.3 \times 10^{-6}$ & 314 \\
\hline & 79 & $1.0 \times 10^{-10}$ & $1.0 \times 10^{-3}$ & $3.6 \times 10^{-5}$ & $1.2 \times 10^{-7}$ & $1.6 \times 10^{-6}$ & 308 \\
\hline & 80 & $1.0 \times 10^{-10}$ & $1.0 \times 10^{-3}$ & $3.6 \times 10^{-5}$ & $4.8 \times 10^{-8}$ & $1.7 \times 10^{-6}$ & 306 \\
\hline & 81 & $1.0 \times 10^{-10}$ & $1.0 \times 10^{-3}$ & $1.1 \times 10^{-2}$ & $1.2 \times 10^{-7}$ & $1.9 \times 10^{-6}$ & 301 \\
\hline & 82 & $1.0 \times 10^{-10}$ & $1.0 \times 10^{-3}$ & $1.1 \times 10^{-2}$ & $1.7 \times 10^{-7}$ & $9.0 \times 10^{-7}$ & 316 \\
\hline & 87 & $1.0 \times 10^{-10}$ & $1.0 \times 10^{-3}$ & $1.0 \times 10^{-1}$ & $6.0 \times 10^{-7}$ & $1.6 \times 10^{-6}$ & 307 \\
\hline & 88 & $1.0 \times 10^{-10}$ & $1.0 \times 10^{-3}$ & $1.0 \times 10^{-1}$ & $2.8 \times 10^{-6}$ & $1.9 \times 10^{-6}$ & 299 \\
\hline & 89 & $1.0 \times 10^{-10}$ & $1.0 \times 10^{-3}$ & $1.0 \times 10^{-1}$ & $8.4 \times 10^{-6}$ & $1.8 \times 10^{-6}$ & 304 \\
\hline & 90 & $1.0 \times 10^{-10}$ & $1.0 \times 10^{-3}$ & $1.0 \times 10^{-1}$ & $1.1 \times 10^{-8}$ & $5.5 \times 10^{-7}$ & 319 \\
\hline & 91 & $1.0 \times 10^{-10}$ & $1.0 \times 10^{-3}$ & $1.0 \times 10^{-1}$ & $2.6 \times 10^{-5}$ & $1.5 \times 10^{-6}$ & 309 \\
\hline & 92 & $1.0 \times 10^{-10}$ & $1.0 \times 10^{-3}$ & $1.0 \times 10^{-1}$ & $5.5 \times 10^{-7}$ & 0.0 & 329 \\
\hline & 93 & $1.0 \times 10^{-10}$ & $1.0 \times 10^{-3}$ & $1.0 \times 10^{-1}$ & $6.6 \times 10^{-6}$ & $4.1 \times 10^{-6}$ & 287 \\
\hline & 94 & $1.0 \times 10^{-10}$ & $1.0 \times 10^{-3}$ & $1.0 \times 10^{-1}$ & $3.0 \times 10^{-9}$ & $2.9 \times 10^{-6}$ & 291 \\
\hline & 95 & $1.0 \times 10^{-10}$ & $1.0 \times 10^{-3}$ & $1.0 \times 10^{-1}$ & $1.2 \times 10^{-6}$ & $1.4 \times 10^{-6}$ & 313 \\
\hline & 96 & $1.0 \times 10^{-10}$ & $1.0 \times 10^{-3}$ & $7.5 \times 10^{-5}$ & $5.2 \times 10^{-6}$ & 0.0 & 329 \\
\hline & 97 & $1.0 \times 10^{-10}$ & $1.0 \times 10^{-3}$ & $1.0 \times 10^{-1}$ & $3.1 \times 10^{-8}$ & $5.7 \times 10^{-6}$ & 282 \\
\hline & 105 & $1.0 \times 10^{-10}$ & $1.0 \times 10^{-3}$ & $1.0 \times 10^{-1}$ & $8.9 \times 10^{-5}$ & $1.4 \times 10^{-6}$ & 312 \\
\hline & 106 & $1.0 \times 10^{-10}$ & $1.0 \times 10^{-3}$ & $1.0 \times 10^{-1}$ & $1.5 \times 10^{-9}$ & $3.5 \times 10^{-6}$ & 288 \\
\hline \multirow[t]{18}{*}{ Riverbed conductance $\left(\mathrm{m}^{2} / \mathrm{d}\right)$} & 1 & $1.0 \times 10^{-10}$ & $1.0 \times 10^{10}$ & $5.7 \times 10^{3}$ & $1.1 \times 10^{4}$ & $2.0 \times 10^{-3}$ & 214 \\
\hline & 2 & $1.0 \times 10^{-10}$ & $1.0 \times 10^{10}$ & $5.7 \times 10^{3}$ & $1.1 \times 10^{4}$ & $3.9 \times 10^{-3}$ & 124 \\
\hline & 3 & $1.0 \times 10^{-10}$ & $1.0 \times 10^{10}$ & $5.7 \times 10^{3}$ & $4.4 \times 10^{2}$ & $6.4 \times 10^{-2}$ & 19 \\
\hline & 4 & $1.0 \times 10^{-10}$ & $1.0 \times 10^{10}$ & $5.7 \times 10^{3}$ & 3.8 & $1.4 \times 10^{-3}$ & 222 \\
\hline & 5 & $1.0 \times 10^{-10}$ & $1.0 \times 10^{10}$ & $5.7 \times 10^{3}$ & 1.2 & $1.7 \times 10^{-5}$ & 269 \\
\hline & 6 & $1.0 \times 10^{-10}$ & $1.0 \times 10^{10}$ & $5.7 \times 10^{3}$ & 1.7 & $7.3 \times 10^{-5}$ & 259 \\
\hline & 7 & $1.0 \times 10^{-10}$ & $1.0 \times 10^{10}$ & $5.7 \times 10^{3}$ & $5.3 \times 10^{4}$ & $4.1 \times 10^{-3}$ & 123 \\
\hline & 8 & $1.0 \times 10^{-10}$ & $1.0 \times 10^{10}$ & $5.7 \times 10^{3}$ & $8.4 \times 10^{3}$ & $1.9 \times 10^{-2}$ & 80 \\
\hline & 9 & $1.0 \times 10^{-10}$ & $1.0 \times 10^{10}$ & $5.7 \times 10^{3}$ & $7.2 \times 10^{1}$ & $1.6 \times 10^{-3}$ & 221 \\
\hline & 10 & $1.0 \times 10^{-10}$ & $1.0 \times 10^{10}$ & $5.7 \times 10^{3}$ & $4.9 \times 10^{4}$ & $6.2 \times 10^{-3}$ & 114 \\
\hline & 20 & $1.0 \times 10^{-10}$ & $1.0 \times 10^{10}$ & $1.9 \times 10^{3}$ & $4.1 \times 10^{4}$ & $3.5 \times 10^{-3}$ & 135 \\
\hline & 19 & $1.0 \times 10^{-10}$ & $1.0 \times 10^{10}$ & $1.9 \times 10^{3}$ & $1.4 \times 10^{3}$ & $1.3 \times 10^{-2}$ & 94 \\
\hline & 11 & $1.0 \times 10^{-10}$ & $1.0 \times 10^{10}$ & $1.9 \times 10^{3}$ & $2.9 \times 10^{5}$ & $4.7 \times 10^{-2}$ & 33 \\
\hline & 14 & $1.0 \times 10^{-10}$ & $1.0 \times 10^{10}$ & $1.9 \times 10^{3}$ & $9.4 \times 10^{2}$ & $9.0 \times 10^{-4}$ & 226 \\
\hline & 13 & $1.0 \times 10^{-10}$ & $1.0 \times 10^{10}$ & $1.9 \times 10^{3}$ & $2.4 \times 10^{4}$ & $2.0 \times 10^{-2}$ & 78 \\
\hline & 15 & $1.0 \times 10^{-10}$ & $1.0 \times 10^{10}$ & $1.9 \times 10^{3}$ & $1.3 \times 10^{2}$ & $8.8 \times 10^{-4}$ & 227 \\
\hline & 17 & $1.0 \times 10^{-10}$ & $1.0 \times 10^{10}$ & $1.9 \times 10^{3}$ & $3.4 \times 10^{2}$ & $3.7 \times 10^{-3}$ & 126 \\
\hline & 16 & $1.0 \times 10^{-10}$ & $1.0 \times 10^{10}$ & $1.9 \times 10^{3}$ & $2.7 \times 10^{2}$ & $3.6 \times 10^{-3}$ & 132 \\
\hline
\end{tabular}


Table 8. Estimates and relative composite sensitivities of parameters varied during the calibration process for the Wood River Valley groundwater-flow model, south-central Idaho.-Continued

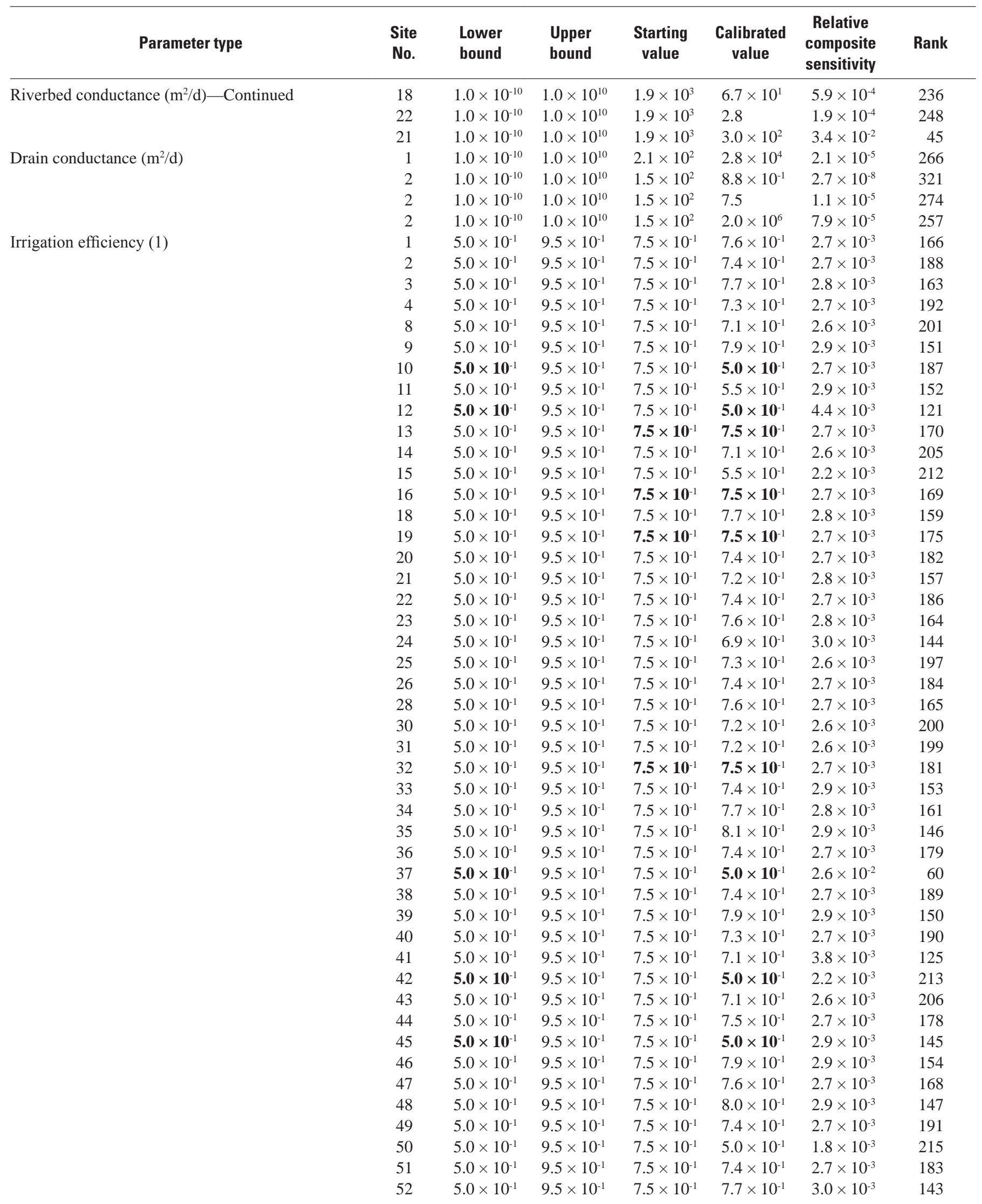


Table 8. Estimates and relative composite sensitivities of parameters varied during the calibration process for the Wood River Valley groundwater-flow model, south-central Idaho._Continued

Tributary underflow scalar (1)

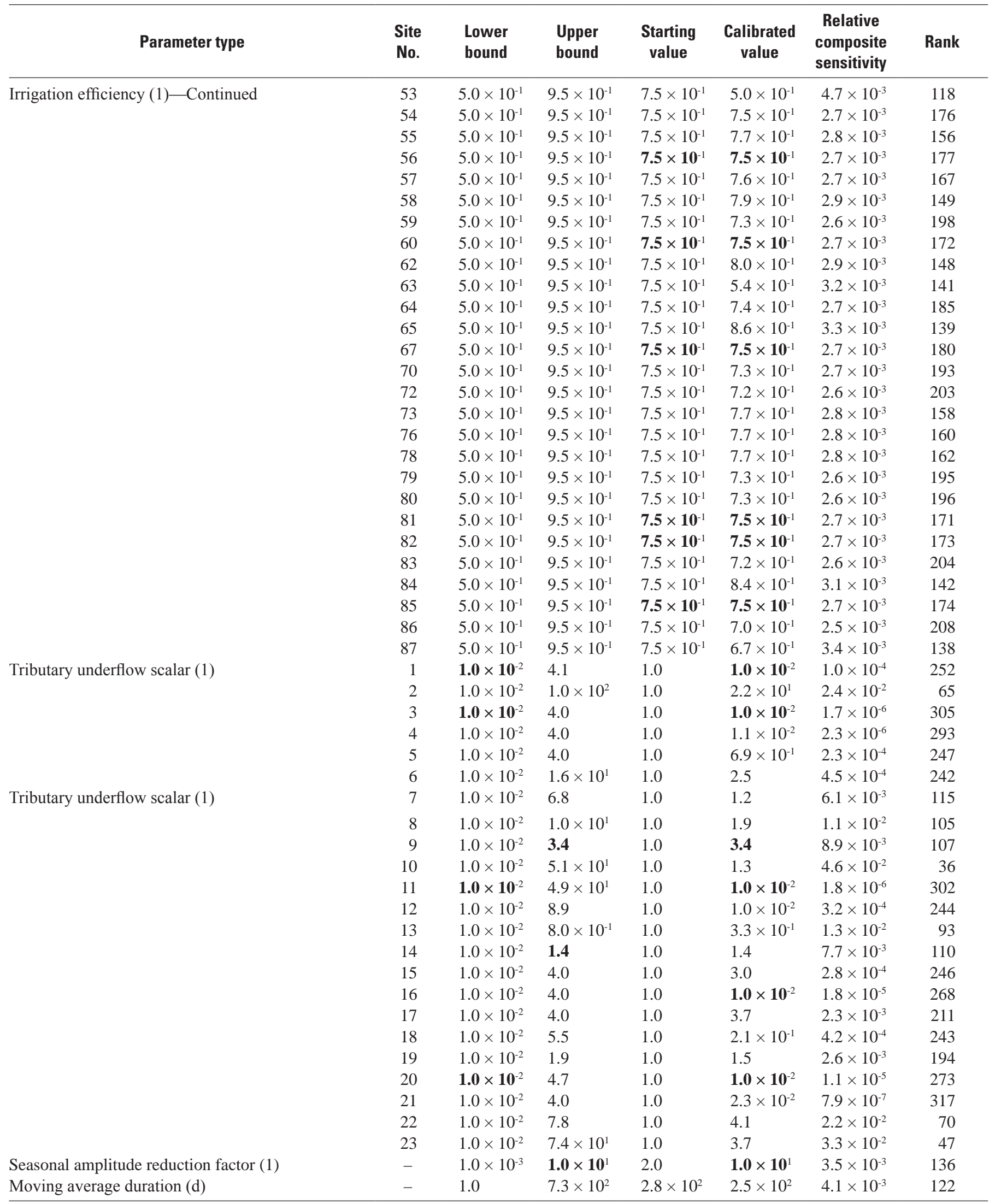




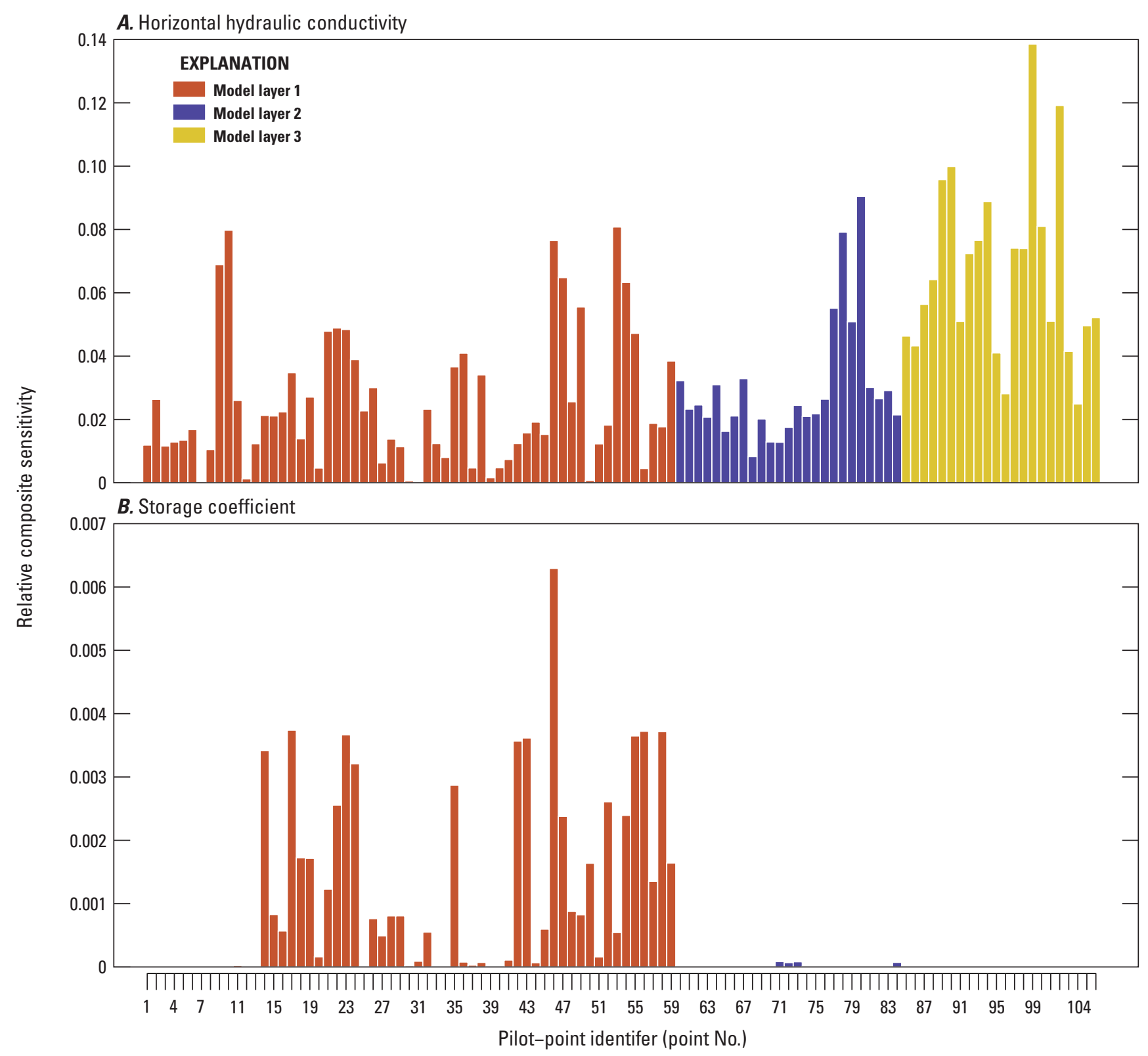

Figure 32. Relative composite sensitivities of adjusted parameters $(A)$ horizontal hydraulic conductivity, $(B)$ storage coefficient, $(C)$ irrigation efficiency, $(D)$ riverbed conductance, $(E)$ drain conductance, and $(F)$ tributary underflow scalar, used in Wood River Valley groundwater-flow model, south-central Idaho. 


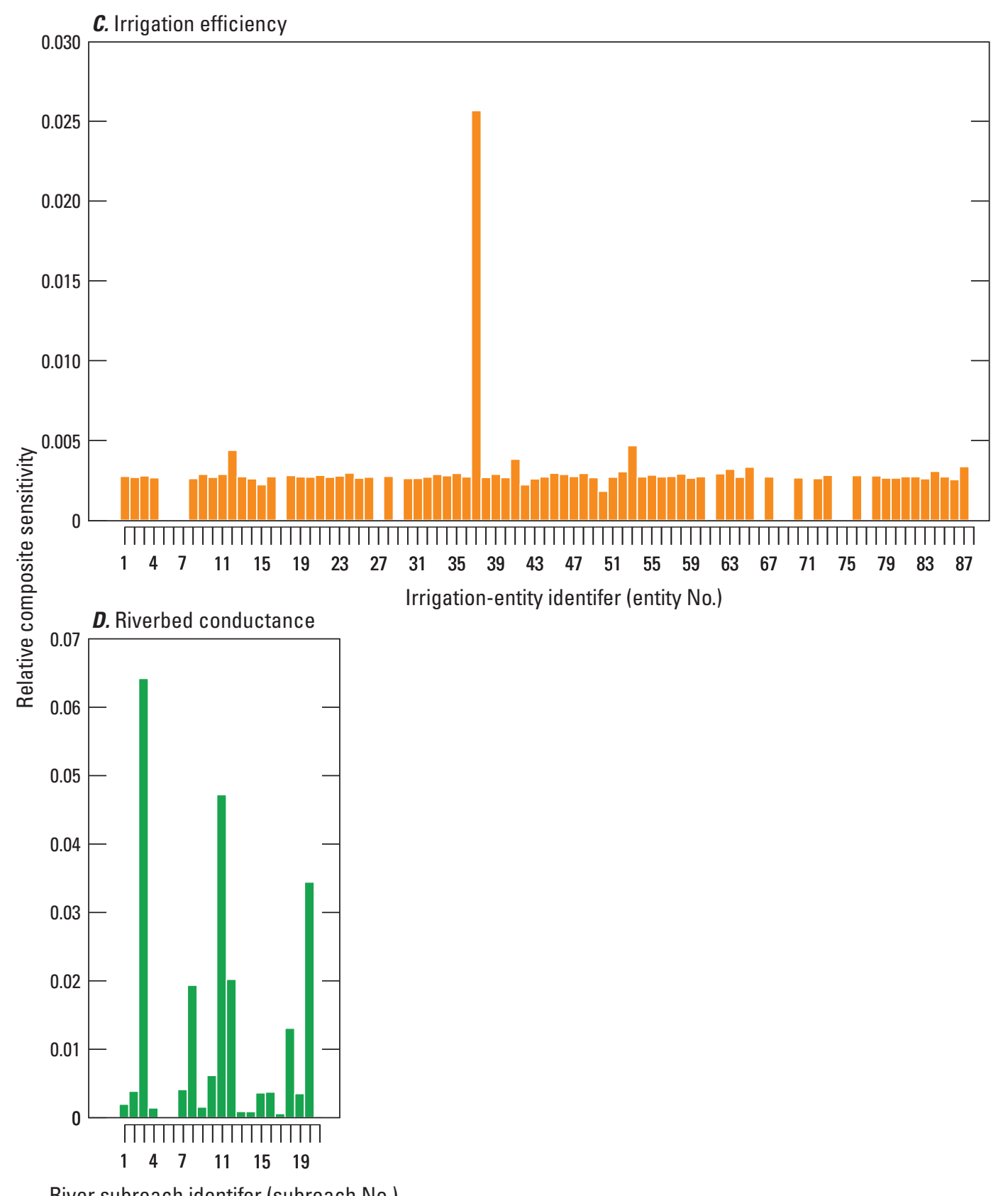

River subreach identifer (subreach No.)

Figure 32.-Continued 


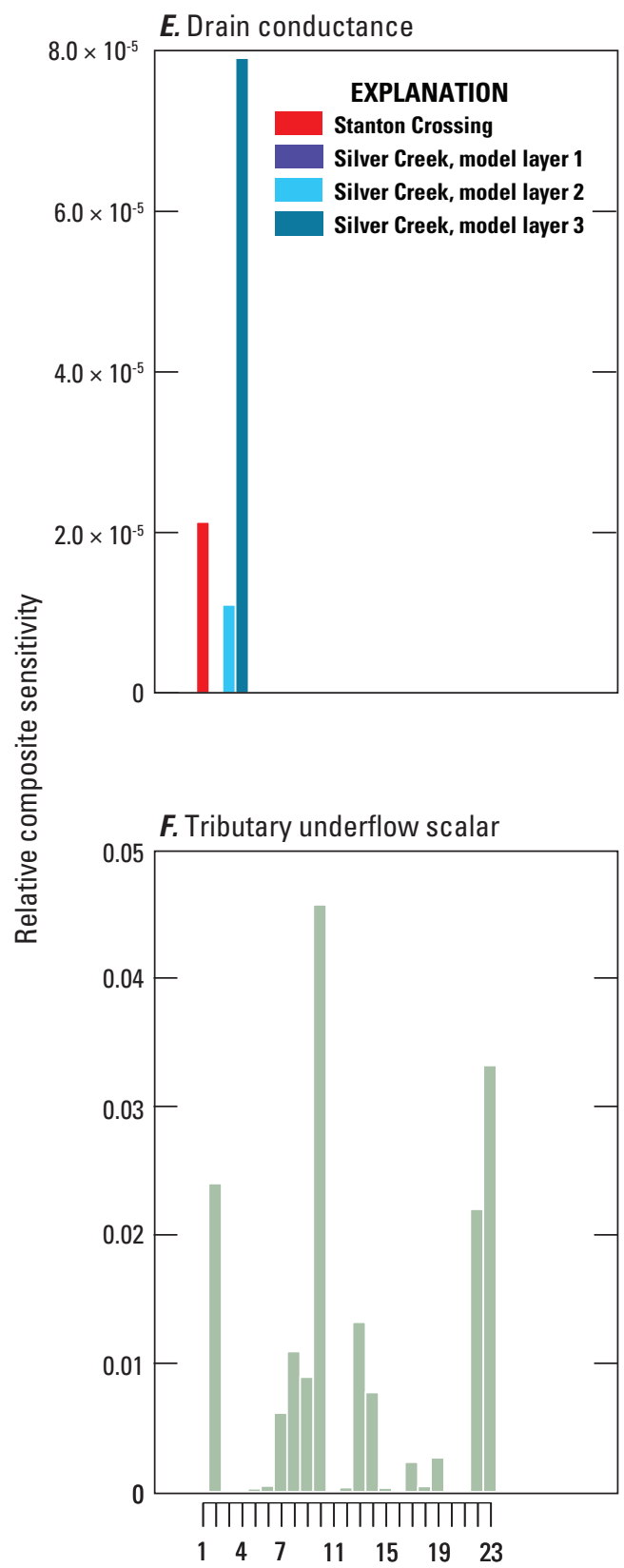

Tributary-valley identifer (tributary No.)

Figure 32.-Continued 


\section{Volumetric Water Budget}

The volumetric water budget discussed in this section is the simulated budget as determined by the calibrated transient model. The average groundwater budget for the 19952010 simulation period is shown in table 9 . Water budget components are as follows:

1. Areal recharge of precipitation and applied irrigation,

2. Streamflow losses and gains - that is, the stream-aquifer flow exchange,

3. Tributary basin underflow,

4. Groundwater pumping from wells, and

5. Groundwater discharge at the Stanton Crossing and Silver Creek outlet boundaries.

The yearly groundwater-budget volumes by model component (including year-to-year storage change) are shown in figure 33. Because some of the budget components are composed of multiple parts or processes, the reader is directed to section, "Hydrologic Boundaries," for a detailed description of the individual components.

Inflow (or groundwater recharge) into the WRV aquifer system originates from three sources (from largest to smallest): (1) Streamflow loss from the Big Wood River and Silver Creek, (2) areal recharge of precipitation and applied irrigation, and (3) underflow from tributary canyons (including the WRV above the northern model boundary) (table 9). Streamflow loss and tributary basin underflow vary relatively little annually (fig. 33); areal recharge shows more variability. Such variability is to be expected because diffuse areal recharge is significantly influenced by precipitation and the availability of surface water for irrigation.

Outflow (or groundwater discharge) from the WRV aquifer system occurs in five ways (from largest to smallest):

1. Streamflow gains in the Big Wood River and Silver Creek,

2. Well pumping,

3. Areal discharge (represented as negative volumetric flow rate values for areal recharge),

4. Subsurface outflow beneath Silver Creek near Picabo, and

5. Subsurface outflow beneath the Big Wood River near Stanton Crossing (table 9).

Substantial annual variability in streamflow gains and well pumping are shown in figure 33. Discharge from the aquifer to streams primarily is controlled by the elevation of the water levels in the aquifer. If precipitation is low then irrigation is met through increased groundwater pumpage. Therefore, reductions in streamflow gains correspond to a reduction of areal recharge from precipitation and an increase in pumpage, both of which occurred during the drier years in the simulation period. Changes in aquifer storage are affected in the same way by areal recharge and pumpage, and also contribute to changes in streamflow gains. Interannual change in storage and corresponding changes in streamflow gains are shown in figure 33 .

Table 9. Water budget specified as volumetric flow rates averaged over the 1995-2010, Wood River Valley aquifer system, south-central Idaho.

[NA, not applicable]

\begin{tabular}{|c|c|c|c|}
\hline \multirow{2}{*}{$\begin{array}{l}\text { Water-budget component in } \\
\text { the groundwater-flow model }\end{array}$} & \multicolumn{2}{|c|}{ Mean volumetric flow rate } & \multirow{2}{*}{$\begin{array}{c}\text { Percentage of } \\
\text { total inflow } \\
\text { or outflow }\end{array}$} \\
\hline & $\begin{array}{l}\text { cubic meters } \\
\text { per day }\end{array}$ & $\begin{array}{l}\text { acre-feet } \\
\text { per year }\end{array}$ & \\
\hline \multicolumn{4}{|l|}{ Inflow } \\
\hline Areal recharge & 444,902 & 131,738 & 37.3 \\
\hline Streamflow losses & 600,503 & 177,813 & 50.3 \\
\hline Tributary basin underflow & 148,737 & 44,042 & 12.5 \\
\hline \multicolumn{4}{|l|}{ Outflow } \\
\hline Areal discharge & 96,952 & 28,708 & 8.1 \\
\hline Streamflow gains & 850,934 & 251,967 & 71.4 \\
\hline Production well pumping & 211,200 & 62,538 & 17.7 \\
\hline Stanton Crossing outlet boundary & 958 & 284 & 0.1 \\
\hline Silver Creek outlet boundary & 32,057 & 9,492 & 2.7 \\
\hline \multicolumn{4}{|l|}{ Inflow - Outflow ${ }^{1}$} \\
\hline Change in aquifer storage & 2,041 & 604 & NA \\
\hline
\end{tabular}

${ }^{1}$ Inflow is water entering the aquifer system and outflow is water leaving the aquifer system. 


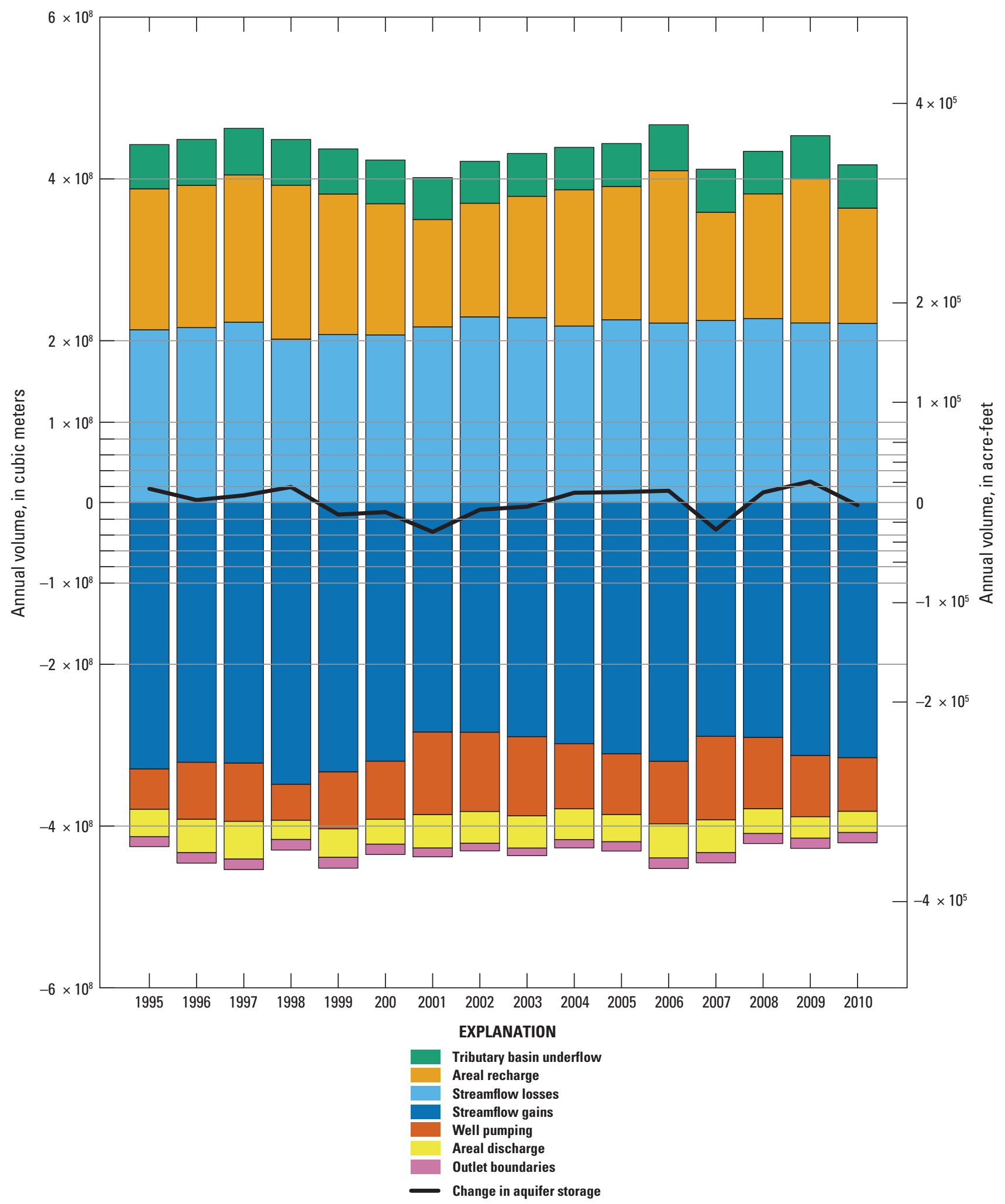

Figure 33. Water-budget components by year, including annual change in storage, for the entire modelsimulation period, 1995-2010, Wood River Valley aquifer system, south-central Idaho. 


\section{Model Limitations and Suggestions for Future Work}

As with any model of a natural system, the Wood River Valley (WRV) groundwater-flow model has limitations and uncertainty-simplifying assumptions must be made to model complex, natural systems. Simulated water-budget components with the least certainty (most uncertainty) are areal recharge beneath non-irrigated lands, tributary basin underflow, and pumping demands for irrigation.

The WRV groundwater-flow model is a regional-scale model; therefore, the model is best used for regional-scale predictions. The model should not be used to model localized phenomena, such as the effect of a single pumping well on a river subreach. This limitation exists because model input data are spatially and temporally sparse, and insufficient for prescribing model boundary conditions at the resolution necessary for localized predictions. For example, the simulated transient river stage of the Big Wood River was correlated based on stage measurements from three streamgages with varying periods of record that did not always coincide with the simulation period (1995-2010). Additionally, a limited number of wells with long-term groundwater-level histories requires a somewhat coarse pilot-point distribution (appendix H, fig. H14). Recall that the hydraulic conductivity (K) distribution is interpolated between pilot points; thus, although each model cell is assigned a unique $\mathrm{K}$ value, the calibration process distributes average values over large areas. This process does not result in a $\mathrm{K}$ distribution that represents actual ("real world") conditions; however, it does result in a $\mathrm{K}$ distribution that allows the simulated aquifer to respond to regional stresses in much the same way that the real world aquifer responds.

The groundwater-flow model described in this report presents a relatively good fit between measured and simulated properties. However, there are components of the model that can be greatly improved with additional data collection and interpretation. The following suggestions for further study, in no particular order, describe information that will advance the understanding of the WRV aquifer system and the groundwater-flow model:

- Perform additional stream-seepage measurements on the Big Wood River within the model domain during the period of snowmelt runoff to improve the definition of river reach gains and losses.

- Measure stream stage at a few (5-6) additional sites between streamgages to improve stream-aquifer flowexchange estimates.

- Measure specific conductance in surface water and groundwater to provide a means of estimating the groundwater contribution to streamflow (Miller and others, 2014). Continuous specific-conductance measurements would improve the definition of gaining reaches in the Big Wood River during the period of snowmelt runoff.

- Extend the model-calibration period to include the most recent measurement data; the additional observations should improve the accuracy of parameter estimates. Specifically, include the following measurement data:

- IDWR measured continuous or bi-monthly groundwater levels at 30 wells during 2012 through 2014.

- Water District 37 measured more groundwater diversions in 2013 and 2014. Based on these measurements, the method used to estimate groundwater diversions for earlier years should be re-evaluated and adjusted if necessary.

- USGS made stream-seepage measurements (three sets) in 2012 and 2013 (Bartolino, 2014).

- USGS measured water levels in wells in October 2012 that are within the monitoring network established by Skinner and others (2007).

- Collect additional groundwater-level measurements in selected areas to improve model calibration, including the upper WRV between the Big Wood River near Ketchum streamgage (13135500) and the Sage Road subreach, the East Fork Big Wood River Valley, and the vicinity of Cove Canyon. Bartolino (2014) suggested that the USGS groundwater-monitoring network measured in 2006 and 2012 needed additional wells in the area north of Ketchum and the Bellevue fan, and that some wells could be removed from the network in the area between Hailey and the East Fork Big Wood River.

- Add a streamgage on Trail Creek close to the model boundary (near Boundary Campground and the Lewis diversion) to provide a transient stream-aquifer flowexchange observation for Trail Creek that may improve the accuracy of the parameter estimates in this area. Trail Creek loses a substantial volume of water to the aquifer within the model domain, as shown by the 2012 and 2013 seepage measurements (Bartolino, 2014) and diversion data reported by Water District 37. These streamflow measurements also would allow Trail Creek to be modeled as a head-dependent river boundary condition.

- Regular (every 4-5 years) April groundwater-level measurements of the USGS monitoring network would provide time-series data to improve model calibration.

- Continue the IDWR spring and autumn discharge measurements of Silver Creek at the North Picabo Road bridge. 
- Use seasonal correlations (provided by the Mapping Evapotranspiration at high Resolution and with Internalized Calibration [METRIC] model) instead of a universal correlation to improve the Normalized Difference Vegetation Index (NDVI) evapotranspiration estimates.

- Use a multi-year average reference evapotranspiration fraction instead of source-target year relationships to improve evapotranspiration estimates. The method used to interpolate evapotranspiration estimates for the current groundwater-flow model sometimes yields unrealistically large values; in these instances, values for alfalfa have been substituted.

- Use a snowmelt-runoff model to improve definition of snowmelt timing and the partition between groundwater infiltration and runoff. This would likely require installation of soil temperature and moisture sensors at existing weather stations.

- Explore alternative methods to better estimate the range of infiltration rates for soils without published infiltration rates. In the current model, the infiltration rate is specified as the geometric mean of a range of saturated infiltration rates of soil types, which is an integrated and somewhat arbitrary method.

- Distribute precipitation over the model domain by the use of interpolation (such as Kriging, inverse distance, or Thiessen polygons) and additional weather-station data. The model currently distributes precipitation over three zones with arbitrary boundaries.

- Install observation wells with multi-level completion depths. This is necessary to better characterize the interaction between the unconfined and confined aquifers.

- Additional discharge measurements of the Baseline Bypass canal are needed to refine the spatial distribution of stream-aquifer flow exchange with both the canal and the lower Big Wood River. These measurements would include diversions into the head of the Baseline Bypass canal, return flow to the Big Wood River, and seepage measurements in the intervening reach.

\section{Summary}

A three-dimensional numerical model of groundwater flow was developed for the Wood River Valley, Idaho, to evaluate groundwater and surface-water availability at the regional scale. The model described in this report can serve as a tool for water-rights administration and water-resource management and planning. The model was completed with support from the Idaho Department of Water Resources, and is part of an ongoing U.S. Geological Survey effort to characterize the groundwater resources of the Wood River Valley. A highly reproducible approach was taken for constructing the Wood River Valley groundwater-flow model. The collection of datasets, source code, and processing instructions used to construct and analyze the model was distributed as an R package.

Flow in the Wood River Valley aquifer was simulated using the MODFLOW-USG groundwater flow model. The flow model simulates transient groundwater conditions between 1995 and 2010 using a weekly time step and steadystate initial conditions. The model domain covers 242 square kilometers (94 square miles) and represents 88 percent of the study area. The active model grid has 100-meter (328-feet) square cells and three layers of varying thickness. The top of model layer 1 is specified at land surface and has a topographic relief of 477 meters (1,565 feet). Model layers 2 and 3 are only active in the southern part of the model area, and extend north to about Hailey.

Specified-flow boundaries were used to simulate tributary basin underflow and areal recharge. Head-dependent flow boundaries were used to simulate the stream-aquifer flow exchange in river reaches and the groundwater discharge at the outlet boundaries of Stanton Crossing and Silver Creek. The model was calibrated by adjusting aquifer hydraulic properties and tributary basin underflow to match simulated and measured values of water level and stream-aquifer flow exchange, using the parameter-estimation program PEST. The model reasonably simulated the measured water-table elevation, orientation, and gradients. Stream-aquifer flow exchange along river reaches also was reasonably predicted by the model.

The WRV groundwater-flow model improves upon previous modeling efforts by including the following:

1. A model extent that fully covers the WRV aquifer system within the main valley floor up to the northern limit of land development at the outlet of the North Fork Big Wood River; previously published models represented the area south of the City of Hailey;

2. A model-calibration dataset spanning 12 years and containing 4,408 field observations, including 931 stream-aquifer flow exchange estimates and 3,477 groundwater-level measurements;

3. A detailed representation of areal recharge from applied irrigation water; and

4. A transparent and open process of data collection, model building, and model calibration that was completed by a technical advisory committee composed of nongovernmental and governmental experts.

The model may be used for examining the valley-wide effects of changes in precipitation and climate on the groundwater and surface water of the WRV. 


\section{References Cited}

Bartolino, J.R., 2009, Ground-water budget for the Wood River Valley aquifer system, south-central Idaho: U.S. Geological Survey Scientific Investigations Report 20095016, 36 p., accessed March 9, 2016, at http://pubs.usgs. gov/sir/2009/5016/.

Bartolino, J.R., 2014, Stream seepage and groundwater levels, Wood River Valley, south-central Idaho, 2012-13: U.S. Geological Survey Scientific Investigations Report 20145151, 34 p., 3 pls. [Also available at http://pubs.usgs.gov/ sir/2014/5151/.]

Bartolino, J.R., and Adkins, C.B., 2012, Hydrogeologic framework of the Wood River Valley aquifer system, southcentral Idaho: U.S. Geological Survey Scientific Investigations Report 2012-5053, 46 p., 1 pl. in pocket. [Also available at http://pubs.usgs.gov/sir/2012/5053/.]

Breckenridge, R.M., and Othberg, K.L., 2006, Surficial geologic map of the Wood River Valley area, Blaine County, Idaho: Moscow, Idaho Geological Survey Digital Web Map 54, scale 1:50,000, 1 sheet. [Also available at http://www. idahogeology.org/Products/reverselook.asp?switch=title\&va lue=Surficial_Geologic_Map_of_the_Wood_River_Valley_ Area,_Blaine_County,_Idaho.]

Brockway, C.E., and Grover, K.P., 1978, Evaluation of urbanization and changes in land use on the water resources of mountain valleys: Moscow, University of Idaho Water Resources Research Institute, 104 p. plus appendix. [Also available at http://contentdm.lib.uidaho.edu/u?/ idahowater,515.]

Brockway, C.E., and Kahlown, M.A., 1994, Hydrologic evaluation of the Big Wood River and Silver Creek watersheds Phase I: Kimberly, University of Idaho Water Resources Research Institute, Kimberly Research Center, 53 p. plus 5 appendixes. [Also available at http://contentdm.lib. uidaho.edu/u?/idahowater,406.]

Chapman, S.H., 1921, Water distribution and hydrometric work, Districts 7 and 11, Big and Little Wood Rivers: Shoshone, Idaho, Annual Report of Watermaster, Districts 7 and 11, 21 p., 67 charts.

de Sonneville, J.L.J., 1972, Development of a mathematical groundwater model with application to aquifers in Idaho: Moscow, University of Idaho, Ph.D. dissertation, 227 p. [Also available at http://contentdm.lib.uidaho.edu/u?/ idahowater,104.]

DHI Group, 2014b, MIKE 11 river modeling unlimited: MIKE Powered by DHI Web site, accessed November 24, 2014, at http://www.mikebydhi.com/products/mike-11.
DHI Group, 2014a, MIKE SHE integrated catchment modeling: MIKE Powered by DHI Web site, accessed November 24, 2014, at http://www.mikebydhi.com/ products/mike-she.

Doherty, J.E., 2005, PEST, model-independent parameter estimation-User manual (5th ed., with slight additions edition): Brisbane, Australia, Watermark Numerical Computing.

Domenico, P.A., and Mifflin, M.D., 1965, Water from low-permeability sediments and land subsidence: Water Resources Research, v. 1, no. 4, p. 563-576.

Forstall, Richard, ed., 1995, Idaho population of counties by decennial census-1900 to 1990: U.S. Census Bureau, accessed November 21, 2014, at http:/www.census.gov/ population/www/censusdata/cencounts/index.html.

Fetter, C.W., 2001, Applied hydrogeology, 4th ed.: Upper Saddle River, New Jersey, Prentice Hall, 598 p.

Freeze, R.A., and Cherry, J.A., 1979, Groundwater: Englewood Cliffs, N.J., Prentice-Hall, 604 p.

Frenzel, S.A., 1989, Water resources of the upper Big Wood River Basin, Idaho: U.S. Geological Survey WaterResources Investigation Report 89-4018, 47 p. [Also available at http://pubs.er.usgs.gov/pubs/wri/wri894018.]

Harbaugh, A.W., Banta, E.R., Hill, M.C., and McDonald, M.G., 2000, MODFLOW-2000, the U.S. Geological Survey Modular Ground-Water Model-User guide to modularization concepts and the ground-water flow process: U.S. Geological Survey Open-File Report 2000-92, 121 p.

Hopkins, C.B., and Bartolino, J.R., 2013, Quality of groundwater and surface water, Wood River Valley, south-central Idaho: U.S. Geological Survey Scientific Investigations Report 2013-5163, 32 p. [Also available at http://pubs.usgs.gov/sir/2013/5163/.]

Johnson, A.I., 1967, Specific yield-Compilation of specific yields for various materials: U.S. Geological Survey Water Supply Paper 1662-D, 74 p. , accessed March 9, 2016, at http://pubs.er.usgs.gov/publication/wsp1662D.

Jones, R.P., 1952, Evaluation of streamflow records in the Big Wood River Basin, Blaine County, Idaho: U.S. Geological Survey Circular 192, 59 p., 1 pl. in pocket. [Also available at http://pubs.er.usgs.gov/usgspubs/cir/cir192.]

Loinaz, M.C., undated, Integrated hydrologic model of the Wood River Valley and stream temperature model of the Silver Creek Basin-Model development, calibration and scenarios report: Report submitted to the Nature Conservancy in 2013, 39 p. [Also available at http://www. savesilvercreek.org/Pdf_files/silver-creek-model-report. pdf.] 
McDonald, M.G., and Harbaugh, A.W., 1988, A modular three-dimensional finite-difference ground-water flow model: U.S. Geological Survey Techniques of WaterResources Investigations, book 6, chap. A1, 586 p. [Also available at http://pubs.er.usgs.gov/publication/twri06A1.]

Miller, M.P., Susong, D.D., Shope, C.L., Heilweil, V.M., and Stopl, B.J., 2014, Continuous estimation of baseflow in snowmelt-dominated streams and rivers in the Upper Colorado River Basin-A chemical hydrograph separation approach: Water Resources Research, v. 50, p. 6,986-6,999, doi:10.1002/2013WR014939.

Moench, A.F., Garabedian, S.P., and LeBlanc, D.R., 2001, Estimation of hydraulic parameters from an unconfined aquifer test conducted in a glacial out- wash deposit, Cape Cod, Massachusetts: U.S. Geological Survey Professional Paper 1629, 70 p., accessed March 9, 2016, at http://pubs. usgs.gov/pp/pp1629/.

Moreland, J.A., 1977, Ground water-surface water relations in the Silver Creek area, Blaine County, Idaho: Boise, Idaho Department of Water Resources, Water Information Bulletin 44, 42 p., 5 pls. in pocket. [Also available at http://www. idwr.idaho.gov/WaterInformation/Publications/default.htm.] Also published as U.S. Geological Survey Open-File Report 77-456, 66 p., plates in pocket. [Also available at http:// pubs.er.usgs.gov/pubs/ofr/ofr77456.]

Newton, G.D., 1978, Application of a simulation model to the Snake River Plain aquifer: Moscow, University of Idaho, M.S. thesis, $82 \mathrm{p}$.

Panday, Sorab, Langevin, C.D., Niswonger, R.G., Ibaraki, Motomu, and Hughes, J.D., 2013, MODFLOW-USG version 1-An unstructured grid version of MODFLOW for simulating groundwater flow and tightly coupled processes using a control volume finite-difference formulation: U.S. Geological Survey Techniques and Methods, book 6, chap. A45, 66 p. [Also available at http://pubs.er.usgs.gov/ publication/tm6A45.]
R Core Team, 2014, R-A language and environment for statistical computing: Vienna, Austria, R Foundation for Statistical Computing, accessed March 9, 2016, at http:// www.R-project.org/.

Skinner, K.D., Bartolino, J.R., and Tranmer, A.W., 2007, Water-resource trends and comparisons between partial development and October 2006 hydrologic conditions, Wood River Valley, south-central Idaho: U.S. Geological Survey Scientific Investigations Report 2007-5258, 31 p., 4 pls., 1 appendix. [Also available at http://pubs.usgs.gov/ sir/2007/5258/.]

Smith, R.O., 1959, Ground-water resources of the middle Big Wood River-Silver Creek area, Blaine County, Idaho: U.S. Geological Survey, Water-Supply Paper 1478, 2 pls., accessed March 9, 2016, at http://pubs.er.usgs.gov/usgspubs/ wsp/wsp1478.

Spitz, Karlheinz, and Moreno, Joanna, 1996, A practical guide to groundwater and solute transport modeling: New York, Wiley, $461 \mathrm{p}$.

Todd, D.K., 1980, Groundwater hydrology (2d ed.): New York, Wiley, 535 p.

U.S. Census Bureau, 2014, State and county quickfacts, Blaine County, Idaho: U.S Census Bureau Web site, accessed November 21, 2014, at http://quickfacts.census.gov/qfd/ states/16/16013.html.

Wetzstein, A.B., Robinson, C.W., and Brockway, C.E., 1999, Hydrologic evaluation of the Big Wood River and Silver Creek watersheds, phase II: Kimberly, University of Idaho Water Resources Research Institute, Kimberly Research Center, 136 p. [Also available at http://contentdm.lib. uidaho.edu/u?/idahowater,412.] 


\section{Appendixes}

Appendixes A-H are PDF files that are available for download at http://dx.doi.org/10.3133/sir20165080/.

Appendix A. An Introduction to the R-Package 'wrv'

Appendix B. Manual for Functions and Datasets in the R-Package 'wrv'

Appendix C. Creating Datasets for the R-Package 'wrv'

Appendix D. Uncalibrated Groundwater-Flow Model for the Wood River Valley Aquifer System, South-Central Idaho

Appendix E. Tributary Basin Underflow into the Wood River Valley Aquifer System, South-Central Idaho

Appendix F. Natural Groundwater Recharge and Discharge in the Wood River Valley Aquifer System, South-Central Idaho

Appendix G. Incidental Groundwater Recharge and Pumping Demand in the Wood River Valley Aquifer System, South-Central Idaho

Appendix H. Calibration of the Wood River Valley Groundwater Flow Model 

Publishing support provided by the U.S. Geological Survey Science Publishing Network, Tacoma Publishing Service Center

For more information concerning the research in this report, contact the Director, Idaho Water Science Center

U.S. Geological Survey

230 Collins Road

Boise, Idaho 83702

http://id.water.usgs.gov 
